Dra. Dwi Nastiti, M.Si 


\section{BUKU AJAR \\ THEMATIC APPERCEPTION TEST \\ dan \\ CHILDREN APPERCEPTION TEST \\ ( Pengantar dan Manual Penggunaan )}

Disusun oleh:

Dra. Dwi Nastiti, M.Si

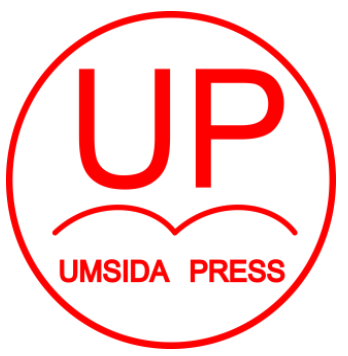

Diterbitkan oleh

UMSIDA PRESS

Jl. Mojopahit 666 B Sidoarjo

ISBN: 978-602-5914-22-5

Copyright@2018.

Authors

All rights reserved 


\section{BUKU AJAR}

THEMATIC APPERCEPTION TEST dan

CHILDREN APPERCEPTION TEST

( Pengantar dan Manual Penggunaan )

\section{Penulis :}

Dra. Dwi Nastiti, M.Si

\section{ISBN :}

978-602-5914-22-5

\section{Editor :}

Septi Budi Sartika, M.Pd

M. Tanzil Multazam, S.H., M.Kn.

\section{Copy Editor :}

Fika Megawati, S.Pd., M.Pd.

Design Sampul dan Tata Letak :

Mochamad Nashrullah, S.Pd

\section{Penerbit :}

UMSIDA Press

\section{Redaksi :}

Universitas Muhammadiyah Sidoarjo

J1. Mojopahit No 666B

Sidoarjo, Jawa TImur

Cetakan pertama, Agustus 2018

(C) Hak cipta dilindungi undang-undang

Dilarang memperbanyak karya tulis ini dengan suatu apapun tanpa ijin tertulis dari penerbit. 


\title{
THEMATIC APPERCEPTION TEST \\ dan \\ CHILDREN APPERCEPTION TEST \\ ( Pengantar dan Manual Penggunaan )
}

\author{
Penulis : Dra. Dwi Nastiti, M.Si \\ Editor : \\ Diterbitkan oleh UMSIDA Press \\ Hak cipta
}

Buku ini merupakan pengantar untuk mengetahui informasi tentang Tes Apersepsi, khususnya Thematic Apperception Test dan Children Apperception Test, yang merupakan salah satu dari rangkaian assesmen psikologi, khususnya assesmen kepribadian. Sudah lazim diketahui bahwa kepribadian seseorang tidak mudah dipahami. Di bidang psikologi, ada sarana yang biasa digunakan untuk mengetahui kepribadian sesorang, yaitu tes psikologi dalam bentuk tes proyeksi. Salah satu bentuk tes proyeksi yang perlu dikuasai penggunaannya adalah alat tes proyeksi dalam bentuk non verbal seperti Thematic Apperception Test dan Children Apperception Test.

Dalam buku ini dijelaskan ide assesmen kepribadian secara umum, dan khususnya pada Thematic Apperception Test dan Children Apperception Test, yang berasal dari appersepsi seseorang saat menghadapi stimulus khusus. Hasilnya, secara teori mampu menggambarkan kepribadian seseorang. Oleh karena itu akan 
dijelaskan dasar teori yang melatarbelakangi pembentukan tes ini, dan yang melatarbelakangi analisis kepribadiannya. Teori yang digunakan dalam tes ini adalah beberapa teori kepribadian yang dikenal di bidang psikologi.

Selain penjelasan teoritis, buku ini menjelaskan petunjuk penggunaan alat tes ini. Penjelasan meliputi bentuk tes-nya, karakteristik alat tes-nya, bagaimana pelaksanaan tes-nya, sampai bagaimana melakukan analisis terhadap hasil tes-nya. Sebagai sebuah pengantar, analisisnya lebih mengarah pada analisis kualitatif dasar, dan diharapkan memberi pemahaman dasar bagi pembaca pemula. Untuk melengkapi pemahamannya, penjelasan akan disertai contoh-contoh, baik contoh gambar maupun respon atau jawaban yang diberikan subyek tes, contoh analisisnya, dan sebagainya. 


\section{KATA PENGANTAR}

Dalam proses belajar mengajar sarana pendukung (seperti buku ajar) sangat dibutuhkan, terutama bagi mahasiswa, didalam usaha untuk lebih mudah memahami materi yang ingin dikuasainya.

Pada mata kuliah yang mengharuskan mahasiswa melakukan praktikum, yaitu pada mata kuliah assesment psikologi. Sarana pendukung selain alat tes, maka materi tentang alat tes juga sangat dibutuhkan mahasiswa, mengingat dalam pelaksanaan praktikumnya mengandung tahapan-tahapan yang harus benarbenar dipahami dan bisa dengan mudah dipraktekkan oleh mahasiswa.

Dengan mempertimbangkan hal-hal tersebut di atas maka penulis, yang juga pengajar salah satu mata kuliah asessmen psikologi, yaitu TAT \& CAT, berupaya menyusun buku ajar TAT \& CAT guna kelancaran proses belajar mengajar. Materi yang tersusun selama ini belum sempurna, tetapi penulis tetap berusaha melengkapi kekurangan yang mungkin ada semata-mata agar mahasiswa memiliki gambaran tentang TAT \& CAT. Materi tentang tes yang berbahasa Indonesia tidak tersedia di luar, karena disusun hanya untuk konsumsi mahasiswa S-1 yang ingin mempelajarinya sesuai kurikulum Program Studi. Penulis berusaha untuk lebih memperkaya dan melengkapi isi materinya, untuk itu kritik dan saran sangat dibutuhkan penulis guna penyempurnaan kekurangan-kekurangan yang ada.

Mudah-mudahan, dengan perkenan Allah SWT, buku ajar tentang TAT \& CAT bisa diterima, dan memberi manfaat dan kebaikan bagi siapa saja yang membutuhkan.

Surabaya,20 Januari 2018

Penulis 


\section{DAFTAR ISI}

HALAMAN IDENTITAS BUKU .................................................. i

HALAMAN KATA PENGANTAR ............................................... ii

HALAMAN DAFTAR ISI ....................................................... iii

$B A B$ I

I. TAT

A. PENGANTAR …........................................... 1

B. TAT : Tes appersepsi dengan teknik proyektif....... 4

C. Teori Kepribadian yang melatarbelakangi TAT ..... 5

D. Aspek Kepribadian yang diungkap dalam TAT ....... 7

E. Kelebihan dan kekurangan TAT ........................ 8

F. Aplikasi penggunaan TAT ................................. 10

II. CAT

A. PENGANTAR ............................................... 13

B. Teori Kepribadian yang melatarbelakangi CAT .... 15

C. TAT : Tes appersepsi dengan teknik proyektif .... 16

D. Aspek Kepribadian yang diungkap dalam TAT ..... 16

E. Kelebihan dan kekurangan TAT .......................... 18

BAB II : PENGENALAN KARTU

PENGANTAR 20

I. TAT

1. Kartu-kartu TAT .............................................. 21

2. Karakteristik Kartu-kartu TAT .......................... 22

II. CAT

Kartu-kartu dan Karakteristik 44

BAB III : ADMINISTRASI TES

I. TAT

1. Hal-hal Yang Harus Diperhatikan 52 
2. Tahap Persiapan 53

3. Tahap Pelaksanaan 56

\section{CAT}

1. Hal-hal Yang Harus Diperhatikan 62

2. Tahap Persiapan 63

3. Tahap Pelaksanaan 63

\section{BAB IV : ANALISIS TES}

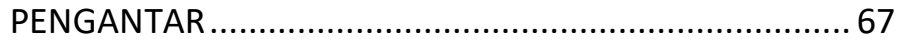

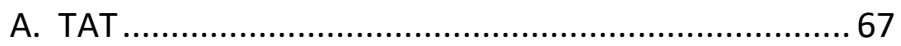

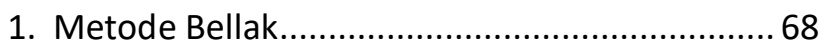

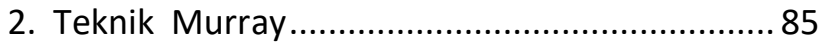

3. Teknik Henry ...................................................... 95

4. Teknik Kesan ..................................................... 107

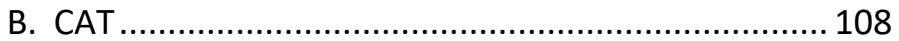

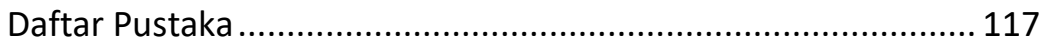

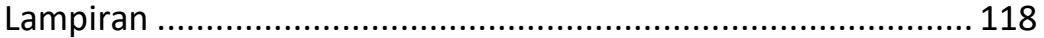




\section{BAB I \\ PENDAHULUAN}

\section{Kemampuan Akhir Yang Direncanakan :}

Setelah mempelajari bab ini, diharapkan mahasiswa mampu memahami tes appersepsi seperti TAT \& CAT sebagai tes dengan teknik proyektif, teori kepribadian yang melatarbelakangi TAT \& CAT, aspek Kepribadian yang diungkap dalam TAT \& CAT, kelebihan-kekurangan TAT \& CAT, serta mengetahui aplikasi TAT \& CAT dalam asesmen kepribadian di berbagai bidang.

\section{TAT}

\section{A. Pengantar}

TAT (Thematic Apperception Test) merupakan salah satu teknik mengungkap dinamika kepribadian yang termanifes dalam interpersonal relationship dan appersepsinya tentang lingkungan.

TAT adalah tes yang mengappersepsikan tema dari suatu gambar yang ambigius/mendua arti. Tes ini berdasar pada fakta bahwa ketika seseorang menginterpretasi situasi sosial yang ambigius, maka ia ternyata menjawab dengan mengekspos kepribadiannya sendiri seperti ia menghadapi fenomena itu. Pada tes ini testee mengappersepsi tema suatu gambar yang sifatnya ambigius. Tema ini oleh testee dikonstruksi berdasar pada gambar yang dilihatnya, dan selanjutnya diproyeksikan sesuai dengan tanggapannya tentang gambar tersebut. Atas dasar appersepsi ini dapat diketahui dan dimengerti bagaimana gambaran kepribadian seseorang. 
TAT disusun oleh Murray dan Morgan pada tahun 1935. Saat itu Henry A. Murray dan Morgan mengembangkan TAT dengan 30 kartu bergambar +1 kartu kosong (blank card). Pada tahun 1938, Murray mengadakan penelitian-penelitian kembali terhadap TAT yang pertama, sehingga pada akhirnya material TAT menjadi 20 kartu, yang terdiri dari 19 kartu bergambar +1 kartu kosong (blank card). Kesembilan belas kartu ini memuat gambar-gambar kabur dalam warna hitam dan putih (Anastasi, 2007).

Pada awalnya TAT dikembangkan sebagai sarana untuk mengukur kekuatan berbagai kebutuhan yang diekspresikan oleh hero (tokoh utama) yang ditunjukkan dalam cerita. Murray juga mencoba menyusun daftar yang didalamnya terdapat 28 kebutuhan (need), yang diharapkan akan membantu menentukan kebutuhan-kebutuhan apa yang mungkin diekspresikan dalam hidup seseorang lewat cerita testee.

Ada beberapa usaha awal, sebelum Morgan dan Murray, oleh para psikolog dan psikiater untuk mendapatkan responrespon yang bermakna dari subyek saat diberi gambar, yang menginspirasi Murray dan Morgan untuk menyusun TAT, misal usaha yang dilakukan oleh :

(1) Britain, tahun 1907 mempublikasikan usahanya untuk memperoleh respon-respon bermakna setelah melakukan penelitian dengan menunjukkan beberapa gambar terhadap anak laki-laki dan perempuan usia 13 - 20 tahun, dan hasilnya ada perbedaan cerita yang dibuat anak lakilaki dengan anak perempuan.

(2) Libby, pada tahun 1908 menggunakan prosedur seperti dilakukan Britain pada subyek anak-anak usia 10 - 14 tahun, 
dan hasilnya cerita anak-anak yang lebih muda obyektif, sedangkan cerita anak-anak yang lebih tua lebih subyektif.

(3) Schwartz, pada tahun 1932 mengembangkan "Social Situation Test" nya yang bisa membantu menciptakan rapport karena bisa membantu mengetahui lebih banyak karakter anak (Gunarsa, 2004).

Ketiga usaha di atas belum bisa mencapai kepopuleran seperti TAT, selain Tes Rorschach. TAT adalah tes yang paling banyak dipakai sesudah tes Rorschach. Dalam penggunaannya, TAT merupakan tes suplemen bagi tes grafis atau tes Rorschach. Soekadji (1982), menyebutkan bahwa analisis pengguna Tes Rorschach lebih menekankan pada analisis proporsi kuantitatif, sedangkan analisis konten (content analysis) kurang dimanfaatkan. Untuk melengkapi analis kualitatifnya, kebanyakan menggunakan TAT. Tes Rorschach bisa membantu mengetahui atau mengestimasi adanya kecemasan, besarnya kecemasan, adanya kebutuhan testee. Sedangkan, TAT bisa membantu mengetahui hal-hal yang dicemaskan (kecemasan apa saja yang dialami testee) dan hierarkhi need yang dimiliki testee.

Gambar-gambar TAT yang ada saat ini merupakan seri ke-3 yang digunakan sejak tahun 1935 . Selain dari penambahan dan penghapusan yang dibuat sejak seri pertama, kartu-kartu seri ke-2 dan ke-3 menjadi istimewa karena dibuat menjadi $2 \times$ ukuran aslinya, dan kenyataan ini mempermudah "testee rapport" dengan gambar-gambar TAT. Berbeda dengan teknik noda tinta, TAT memiliki stimuli yang jauh lebih terstruktur dan meminta testee memberi respon verbal yang lebih kompleks, terorganisir dan bermakna (Anastasi, 2007). 
TAT dianggap sebagai metode yang berguna bagi para "interpreter" yang cukup terlatih untuk mencoba "mengungkapkan" dorongan-dorongan yang sifatnya dominan, juga emosi-emosi, sentimen-sentimen, serta kepribadian yang kompleks, termasuk konflik-konflik yang dialami testee.

Secara khusus, tes ini mampu mengungkap kecenderungankecenderungan yang mendasari hambatan pada klien, yang seringkali tidak mau atau tidak dapat mengakui adanya gangguan dan hambatan tertentu dalam dirinya secara tidak sadar.

\section{B. TAT : Tes appersepsi dengan teknik proyektif}

TAT menjadi salah satu tes yang termasuk dalam kelompok tes proyeksi. Tes proyeksi merupakan suatu alat ukur kepribadian yang dalam pengungkapannya menggunakan media atau materi sebagai tempat untuk memproyeksikan dorongan, perasaan, atau sentimen individu. Sebagai tes proyeksi, TAT digunakan dengan tujuan untuk mengungkap motif, nilai, keadaan emosi, need yang sukar diungkapkan dalam situasi wajar dengan cara individu memproyeksikan pribadinya melalui obyek atau stimulus di luar individu.

Dalam pengelompokkannya, TAT termasuk dalam kelompok tes proyeksi non verbal, yaitu tes proyektif yang memakai bahasa hanya instruksinya saja, tetapi stimulusnya bisa berupa gambar cerita, bercak tinta,atau goresan tangan. Dalam usaha untuk mengungkapkan kepribadian, TAT menggunakan stimulus dalam bentuk gambar. Gambar yang disajikan dianggap sebagai alat tes imajinasi, sehingga minat testee akan tercurah pada tugasnya dan lupa pada kepekaan 
dirinya serta lupa untuk mempertahankan penampilannya. Akibatnya, tanpa disadari testee telah mengatakan hal-hal yang berkenaan dengan pelaku cerita, yang berkaitan dengan dirinya sendiri. Hal-hal yang diceritakan antara lain adalah hal-hal yang enggan diceritakan bila ditanya secara langsung.

Prosedur yang ditempuh dalam penggunaan alat tes ini adalah dengan memperlihatkan kepada testee suatu rangkaian gambar - gambar, dimana testee diminta untuk mau menceritakan secara spontan tentang gambar yang telah dilihatnya. Dengan melakukan analisis cerita yang disampaikan testee terungkap bagian-bagian penting kepribadian testee. Asumsi (dasar pemikiran) yang digunakan TAT sama dengan pendekatan yang digunakan tes-tes lain yang termasuk dalam kelompok tes proyeksi non-verbal, yaitu :

(1) Adanya kecenderungan bahwa testee akan menginterpretasikan sesuatu yang tidak jelas (stimulus yang ambigius) berdasar pengalaman masa lalunya dan kebutuhan-kebutuhannya saat ini.

(2) Adanya kecenderungan bahwa saat testee membuat cerita, akan mengambil bahan cerita dari perbendaharaan pengalaman sebelumnya dan mengekspresikan perasaan senang/tidaksenang, maupun kebutuhan yang disadari atau tidak disadari.

\section{Teori Kepribadian yang melatarbelakangi TAT}

(1) Teori Kepribadian Murray :

Teori kepribadian Murray merupakan teori utama yang digunakan untuk pemakaian TAT di awal pengembangannya. Inti konsep-konsep teori Murray 
berfokus pada bagaimana individu berinteraksi dengan lingkungan, meliputi :

a. bagaimana individu dipengaruhi oleh kekuatan eksternal

b. bagaimana ragam kebutuhan, sikap, dan nilai - nilai individu mempengaruhi reaksi individu terhadap dunia di sekitarnya.

(2) Teori Psikoanalisa :

Cerita yang dihasilkan sering menggambarkan adanya konflik internal, serta usaha mengatasi konflik yang ada. Dalam hal ini, konsep teori psikoanalisa sangat membantu didalam usaha menginterpretasi hasil tes dengan TAT, meliputi :

(1) Gambar-gambar pada kartu TAT ada yang melukiskan kemungkinan adanya konflik superego seperti pada kartu I (gambar anak laki-laki yang termenung, dan di depannya ada biola di atas meja), atau kartu 8BM (gambar seorang remaja laki-laki yang memandang lurus ke depan. Tong tempat senapan tampak pada satu sisi, dan gambar latar belakang adalah peristiwa berlangsungnya operasi bedah, seperti angan-angan) yang menggambarkan kemungkinan adanya kecemasan kastrasi (Marnat, 2010).

(2) Cara penyekoran yang dipakai Bellak mengarah pada konsep-konsep dalam teori psikoanalisa, seperti : mekanisme pertahanan ego yang digunakan didalam menghadapi konflik dan ketakutan, atau adekuasi superego, dsb. 


\section{Aspek Kepribadian yang diungkap dalam TAT}

TAT dianggap sebagai metode yang bisa digunakan untuk mengungkapkan sebagian dorongan, emosi, sentimen, kompleks, dan konflik kepribadian yang dominan. TAT disusun dengan teori dasar dari Murray yang dikenal dengan Teori Kebutuhan Manusia. Murray mengungkapkan 7 (tujuh) aspek yang bisa digali dengan TAT, yaitu :

(1) Aspek Mental :

Aspek yang mengungkap pengalaman testee yang luas, dan pemikiran yang lebih matang.

Aspek ini tergambar dari organisasi cerita :

- Sebab-akibat cerita,

- Kelogisan,

- Konsep cerita yang cermat, runtut, dan terpadu,

- Ketepatan konsep cerita dengan gambar,

- Bahasa yang digunakan mudah dipahami.

(2) Aspek Imajinasi :

Aspek yang mengungkap kekuatan daya khayal dan kreativitas testee, yaitu : seberapa jauh testee dapat memperkaya persepsi terhadap gambar-gambar TAT dengan isi cerita yang mengekspresikan pengalaman / latar belakang pribadi.

(3) Aspek Dinamika Keluarga :

Aspek yang mengungkap latar belakang keluarga (ayah, ibu, atau saudara kandung). Aspek ini dapat tergambar dari reaksi testee terhadap kartu-kartu (terutama pada kartu 5, 6 BM, 7 BM, 7GF, 8, 9) :

- Apakah terjadi blocking dalam menanggapi kartu tersebut, atau

- Apakah ada emosi (marah, senang, dll.) yang berkaitan dengan kartu-kartu tersebut. 
(4) Aspek Penyesuaian terhadap Diri Sendiri :

Aspek yang mengungkap apakah testee dapat menerima/ menolak keadaan dirinya (kelebihan - kekurangannya)

(5) Aspek Emosi :

Aspek yang mengungkap reaksi yang lebih dominan muncul. Aspek ini dapat tergambar dari ekspresi wajah dan reaksi tubuh (body language)

(6) AspekPenyesuaianSeksual : Aspek yang mengungkap bagaimana :

a. Hubungan heteroseksual testee dengan teman sebaya (laki-laki / perempuan)

b. hubungan orang tua - anak.

(7) Aspek Behavioral :

Aspek yang mengungkap perilaku testee, yang dapat tergambar dari proses pelaksanaan tes, perilaku apa yang muncul (misal : emosi, gembira sekali, dl

\section{E. Kelebihan dan kekurangan TAT}

Dalam penggunaannya, TAT masih tergolong 10 instrumen yang paling sering digunakan, dan menempati urutan ke-4 sebagai alat yang melahirkan paling banyak penelitian setelah MMPI, Skala-skala Inteligensi Wechsler, dan Rorschach. Dibalik itu, TAT memiliki kelebihan dan kekurangan antara lain :

\section{Kelebihan-kelebihan TAT}

a. Teknik proyektif pada TAT memungkinkan tester mengetahui srtuktur-struktur yang tertutup dan dalam dari kepribadian seorang individu (testee) tanpa disadari oleh individu tersebut, karena teknik proyektif dalam TAT disamarkan sehingga pertahanan kesadaran (ego) mengendur. 
b. Menekankan pada sifat global dari kepribadian (melihat kepribadian secara keseluruhan) yang mencakup aspek emosional, motivasional, interpersonal, defens-defens, tingkat intelektual secara umum, kelancaran verbal, originalitas, maupun gaya individu dalam mengatasi masalah, bukan melihat kepribadian sebagai sekedar kumpulan berbagai sikap/ciri tertentu.

c. Mudah bagi tester dalam menciptakan rapport

\section{Kekurangan-kekurangan TAT}

a. Sulit diperoleh konsistensi internal dan reliabilitas tesretes yang adekuat, karena :

- Administrasi dan cara penyekoran dalam TAT kurang terstandardisir. Pengguna TAT tidak harus menggunakan seluruh kartu, banyak yang menggunakan kartu dengan jumlah dan macam kartu yang berbeda. Marnat (2010), TAT masih tetap belum dianggap telah mencapai derajat standardisasi yang sebanding dengan MMPI/MMPI-2 atau WAIS-III, karena tidak ada sistem penskoran dan interpretasi yang jelas dan disepakati .

- Pada umumnya, pengguna TAT sering mengandalkan pengalaman mereka saat menginterpretasi respon testee, termasuk saat menentukan jenis gangguan yang dialami klien karena kurangnya data normatif dan lebih mementingkan kekayaan dan kekomprehensifan materi yang dikaji. Gieser \& Stei (1999), metode administrasi (terutama dalam hal jumlah, urutan, dan tipe kartu yang diberikan) yang digunakan klinisi masih bervariasi. Akibatnya, TAT dianggap alat yang sangat IMPRESIONISTIK, dengan interpretasi yang seringkali 
berasal dari kombinasi antara intuisi dan pengalaman klinis (Marnat, 2010).

b. Aspek-aspek stabil dari kepribadian kurang bisa tergambarkan

- Banyak faktor situasional yang bisa mempengaruhi respon testee, seperti : suasana perasaan, stress, perbedaan dalam instruksi, dan sebagainya.

c. Data validitas TAT yang diperoleh dari penelitianpenelitian sebelumnya banyak yang kabur

- Tidak ada peningkatan validitas instrumental TAT saat ada dalam baterai tes.

- Kontroversi tentang validitas \& reliabilitasnya masih terus berlanjut (Hunsley, Lee, \& Wood, 2003, dalam Marnat, 2010). Meskipun demikian TAT masih berada di urutan ke-6 sebagai tes yang paling sering digunakan para psikolog klinis, dan urutan ke-2 sebagi tes proyektif yang direkomendasi untuk kompetensi trainee psikologi klinis di semua benua Eropa, India, Afrika Selatan, China, Amerika Selatan, Asia, Uni Soviet, serta tes yang paling sering digunakan untuk penelitian lintas budaya (Marnat, 2010)

\section{F. Aplikasi penggunaan TAT}

TAT dipakai luas sebagai instrumen diagnosis klinis dan instrumen penelitian, tetapi secara umum hasil tes dengan TAT bisa dimanfaatkan untuk :

1. Pengukuran kepibadian sebagai satu kesatuan utuh (untuk mengungkap dinamik akepribadian individu).

Banyak peneliti yang meneliti apakah tes ini benar-benar mengungkap materi-materi tak sadar dan sifat khas kepribadian sebagaimana diklaim oleh Murray. TAT juga bisa 
mengungkap temperamen, kemasakan emosi, kemampuan intelekstual, kemampuan verbal,

2. Pelengkap tes psikologi lainnya (dalam baterai tes).

TAT melengkapi tes psikologi lain (misal : TAT dikombinasi dengan tes Rorschach, dengan Figure Drawing Test, dsb.), karena TAT menghasilkan : (1) Informasi yang kaya, beraneka ragam, dan kompleks, (2) data pribadi, yang secara teoritis mem-bypass resistensi sadar subyek.

3. Riset penggunaan TAT di berbagai bidang, terutama bidang klinis.

Riset klinis banyak yang menyimpulkan sikap dan ciri yang diungkap oleh TAT berkorelasi kuat dengan hasil tes kepribadian yang lain.

4. Lain-lain :

Selain digunakan untuk penelitian (terutama klinis), TAT juga sering digunakan untuk keperluan :

(a) Special selection pada pekerjaan-pekerjaan yang memiliki resiko tinggi, seperti : pilot, pegawai pemerintah "khusus", pimpinan eksekutif, dsb.

(b) Tes untuk mengevaluasi potensi perwira. Tes ini pernah digunakan oleh Dewan Seleksi Layanan India, dan secara luas telah digunakan di Perancis dan Argentina

(c) Diagnosis dari TAT (sebagai tes psikologi lain).

Sering digunakan untuk menegakkan diagnosis klinis. TAT akan sangat membantu pengguna didalam penanganan kasus klinis, yaitu dalam rangka menemukan karakteristik dan kapasitas perilaku klien, yang selanjutnya digunakan sebagai bahan masukan didalam proses konseling, atau memberikan saran dan rekomendasi untuk kebutuhan penyesuaian diri klien, serta mengevaluasi hasil suatu intervensi klinis : 
- Biasanya digunakan untuk mencoba menginterpretasi segala bentuk tingkah laku yang menyimpang /abnormal /mengalami gangguan, seperti : stress tinggi, psikosomatis, neurosis, psikosis. Hary (2011) TAT mampu mengungkap kecenderungan depresi, apresepsi distorsi, reaksi terhadap tekanan luar, ambivalensi, dan mekanisme pertahanan diri

- Ada peneliti yang menggunakan TAT untuk bisa memahami gangguan kepribadian seperti : kepribadian narsistik, kepribadian antisosial, dsb .

- Mengevaluasi tersangka kejahatan (pada pemeriksaan forensik).

(c) Terapi untuk menangani pasien.

TAT bisa dimanfaat sebagai langkah pertama /pengantar untuk melaksanakan serangkaian interviu dalam psikoterapi atau pelaksanaan psikoanalisis yang sifatnya tidak mendalam. Hary (2011), dengan menggunakan TAT pengguna bisa memastikan kemampuan, kekuatan, dan kelemahan klien, baik sebelum, selama, maupun sesudah intervensi dilakukan.

Penggunaan alat tes TAT seringkali berangkat dari anggapan bahwa TAT :

(1) Teknik yang bisa digunakan untuk mengetahui dinamika kepribadian individu yang termanifes dalam : a. interpersonal relationship ; dan b. appersepsi individu tentang lingkungannya.

(2) Secara spesifik, merupakan tes konten yang bisa menunjukkan actual dynamics of interpersonal, misal : relasi testee dengan figur otoriter, membandingkan jenis kelamin, atau family relationship. 


\section{CAT}

\section{A. Pengantar}

CAT merupakan salah satu instrumen psikologi yang stimulusnya berupa kartu bergambar yang dirancang untuk membangkitkan imajinasi yang berhubungan dengan masalahmasalah yang sering dialami anak-anak, seperti masalah makan (masalah aktivitas oral), persaingan sesama saudara, hubungan orang tua dan anak, agresi, latihan buang air kecil dan besar, serta pengalaman anak-anak lainnya.

CAT mulai disusun karena adanya kekecewaan sejumlah peneliti yang menganggap TAT kurang membantu saat dilakukan penelitian untuk populasi yang berbeda, dan TAT menghasilkan cerita-cerita negatif yang rendah energi. Selain CAT, muncul banyak tes sejenis, misal SAT (Senior Apperception Test), RACT (Roberts Apperception Test for Children), TEMAS (Tell Me A Story Test) , dll.

CAT merupakan tes yang dirancang untuk anak-anak yang berumur antara $3-10$ tahun. Tes ini dikembangkan atas ide Bellak dan Ernst Kris, yang kemudian menginspirasi Bellak dan istrinya (Sonya Sorel Bellak) kemudian mengembangkan CAT pada tahun 1949. Selain itu, menurut Bellak, TAT lebih sesuai bila digunakan untuk testee dewasa dan remaja, tetapi cenderung kurang sesuai untuk anak-anak.

Bentuk tes CAT berupa gambar-gambar binatang dalam konteks sosial manusia. Ada alasan mengapa gambar-gambar kartu CAT berupa gambar binatang, dan hanya berjumlah 10 karena : 
(a) Anak-anak mempunyai rentang perhatian yang sempit sehingga mereka membutuhkan lebih sedikit kartu.

(b) Anak-anak dengan mudah mampu memproyeksikan apa yang dialami pada gambar-gambar binatang daripada gambar-gambar manusia (Bellak \& Abrams, dalam Marnat, 2010).

Setelah beberapa waktu penggunaannya, CAT mengalami perkembangan, mulai dari adaptasi sampai pengubahan figur dalam gambar, seperti :

(1) Adaptasi dari CAT, pernah dilakukan di Jepang (1956), di India (1960), termasuk di Indonesia (1974)

(2) Penyusunan tes tambahan oleh Bellak (1952), yaitu CAT-S (CAT- Supplemen), sebagai tes tambahan yang didisain untuk melengkapi gambar-gambar yang menjelaskan tentang situasi yang belum tentu berkaitan dengan masalah masalah umum tetapi cukup sering terjadi dan dialami anak-anak, seperti saat anak-anak menghadapi situasi khusus, misal: CAT-S gambar 5 diberikan untuk anak-anak yang memiliki disabilitas fisik (sementara atau permanen), atau anak yang mengalami gangguan psikosomatis atau hipokondriasis, dsb.

(3) Penyusunan CAT- H (CAT- Human) oleh Bellak (1965), sebagai langkah modifikasi yang didasarkan atas temuan beberapa penelitian tokoh lain, yang menyimpulkan kalau rangsang berupa gambar manusia hasilnya lebih banyak bercerita bila berhadapan dengan stimulus berupa gambar manusia, meskipun ada beberapa penelitian lainnya tidak menunjukkan hasil yang signifikan. CAT-H bisa digunakan untuk anak-anak yang lebih tua, terutama di atas usia 10 tahun. 


\section{B. Teori Kepribadian yang mendasari CAT}

Teori yang mendasari CAT tidak berbeda jauh dengan teori yang mendasari TAT, kecuali CAT menggunakan stimulus berupa gambar binatang. Teori yang mendasari adalah :

1. Teori Psikoanalisa :

Teori ini mendasari penggunaan stimulus berupa gambar binatang pada CAT, karena menurut teori Psikoanalisa anakanak lebih mudah mengidentifikasi binatang daripada manusia. Asumsi ini berangkat dari kenyataan bahwa :

a. Hubungan emosional dengan binatang lebih mudah ditangani oleh anak-anak

b. Binatang dianggap "lebih remeh" daripada orang dewasa dan binatang dianggap "kalahan" seperti mereka anakanak.

c. Binatang memegang peranan utama adanya phobia pada anak-anak, juga menjadi figur identifikasi pada mimpimimpi anak-anak.

d. Di lapisan kesadaran, binatang merupakan figur teman yang penting bagi anak-anak

e. Sifat dorongan oral dan anal pada binatang menguatkan adanya kedekatan binantang dengan anak-anak.

f. Stimulus binatang menghasilkan cerita yang lebih "kaya" dibanding saat stimulusnya adalah figur manusia.

2. Hasil beberapa penelitian yang mendukung teori psikoanalisa menyebutkan bahwa fantasi hewan pada anak-anak berhubungan erat dengan psikodinamika anak-anak dengan jenis binantang yang paling mendominasi fantasi anak-anak, figur manusia berhubungan dengan "rumah" sedangkan 
binatang bisa mengatasi kekuatan untuk melawan (Bellak, 1975)

\section{TAT : Tes appersepsi dengan teknik proyektif}

Tes CAT digolongkan sebagai tes proyektif, tes ini merupakan derivat dari TAT yang digunakan untuk anak-anak. Sebagaimana tes proyeksi non verbal lainnya, CAT menggunakan stimulus berupa gambar-gambar yang ambigius guna mendapat respon berupa cerita yang mewakili ide-ide, kebutuhan - kebutuhan, cita - cita, serta penerimaan anak di lingkungan orang dewasa, atau sikap pribadi terhadap masalah pemuasan oral, sibling rivalry, dan fantasi tentang agresivitas.

Sebagai tes proyeksi, cerita yang dibuat anak-anak setelah mendapat tes CAT dianggap mewakili "private world" anakanak. Berlaku asumsi bahwa stimulus dalam bentuk gambargambar figur binantang merupakan samaran nyata dari perilaku menurut anak-anak, seperti : perilaku agresif dan perasaan negatif lainnya lebih berhubungan dengan singa daripada figur ayah, dsb (Bellak, 1975).

\section{Aspek yang diungkap dalam CAT}

Secara teori, CAT belum bisa mengungkap kepribadian anak secara utuh, karena menurut Abt \& Bellak (1959) kepribadian dipandang sebagai suatu proses daripada sekedar suatu koleksi atau kumpulan dari trait-trait yang relatif menetap yang digunakan individu dalam merespon stimulus, yang mengalami pertumbuhan dan perkembangan (Nastiti, 2013). Anak-anak masih tumbuh dan berkembang, sehingga dikatakan anak-anak belum memiliki profil kepribadian. 
Seperti telah dijelaskan di atas, bisa ditarik kesimpulan bahwa aspek yang bisa digali dari CAT tentang testee anak-anak adalah :

1. Secara umum :

Dengan CAT bisa diketahui "private world" anak-anak, seperti ide-ide, kebutuhan-kebutuhan, cita-cita, serta penerimaan anak di lingkungan orang dewasa, atau sikap pribadi terhadap masalah pemuasan oral, sibling rivalry, dan fantasi tentang agresivitas.

2. Secara khusus :

Dari tema-tema yang bisa muncul di setiap gambar CAT, bisa diketahui antara lain :

a. Sikap anak terhadap orang tua, meliputi :

- Identifikasi terhadap sikap orang tua

- Persepsi anak tentang figur ayah

- Hubungan antara ibu-anak

- Peran anak di dalam keluarga

b. Sikap anak terhadap saudara

- "sibling rivalry" (persaingan antar saudara)

- Sikap terhadap saudara, misal : iri hati, merasa tidak adil

c. Sikap anak tentang diri sendiri

- Keinginan untuk mandiri dan berkuasa

- Sikap agresi anak (terhadap orang dewasa)

- ketakutan akan agresi

- Kecemasan dan ketakutan berpisah dengan orang tua

- Konsep moral anak ("kejahatan dan hukuman")

- "toilet- training" (latihan dan kedisiplinan terhadap anak)

- indikasi regresi 


\section{E. Kelebihan-kekurangan CAT}

\section{Kelebihan-kelebihan CAT}

Sebagai suatu instrumen psikologi dalam bentuk gambar, CAT dianggap tes yang relatif bebas budaya, artinya dapat digunakan di berbagai budaya.

\section{Kekurangan-kekurangan CAT}

Gunarsa (2004), sulit ditemukan fenomena seperti dalam teori psikoanalisa (misal : adanya ketakutan kastrasi, dsb.), karena faktor-faktor seperti :

a. Usia

Pada anak usia 3-5 tahun (di bawah umur 6 tahun), jawabannya hampir selalu bersifat deskriptif sehingga jawaban mereka kurang mengandung nilai-nilai interpretatif maupun diagnostik. Hal ini disebabkan karena belum optimalnya fungsi mental, sehingga belum mampu merangkai apa yang dilihat sampai menjadi suatu cerita. Menurut Piaget, anak baru bisa mengembangkan kemampuan untuk bernalar logis ketika anak berusia 711 tahun, saat memasuki tahap Opersional Kongkrit (Santrock, 2009). Apalagi pada anak-anak dengan taraf inteligensi di bawah rata-rata.

b. Gambar

Stimulus gambar binatang tidak semuanya dikenali anakanak karena :

- tidak popular bagi anak di daerah-daerah tertentu. Gambar 1 adalah gambar kanguru, misal, hanya dikenal/populer pada anak yang pernah ke kebun binatang, sering membaca buku atau mendengar cerita dari guru.

- gambarnya terlalu kabur sehingga sulit dikenali, dan cerita yang dibuat tidak sesuai dengan gambar . 
Dampaknya, anak dipaksa berpikir, sehingga aspek proyeksi tidak muncul. Adakalanya anak kemudian menolak untuk bercerita. Kalaupun bersedia maka cerita yang dihasilkan cenderung berbentuk deskripsi atau ngawur (psikoanalisa : ini bentuk defens).

c. Interpretasi

Tidak semua cerita bisa dinterpretasi dengan mudah :

- harus mengetahui dasar teori yang digunakan untuk interpretasi, seperti teori psikoanalisa.

- harus melakukan observasi guna mengetahui hal-hal yang melatarbelakangi jawaban anak.

- harus melakukan analisis dan interpretasi protokol CAT secara bebas .

Meskipun Bellak telah membuat "CAT Blank and Analysis Sheet", jarang ada yang menggunakan. Biasanya untuk tujuan latihan masih dianjurkan menggunakan "CAT Blank and Analysis Sheet" dari Bellak.

CAT tetap bisa digunakan pada anak-anak, tetapi perlu mempertimbangkan hal-hal di atas. Solusinya :

1. Menganggap stimulus gambar bukan sebagai tes melainkan sebagai stimulus awal agar terjadi asosiasi bebas.

2. Tes diberikan dalam suasana bermain.

3. Mental Age anak minimal 6 tahun.

4. Taraf inteligensi minimal rata-rata.

5. Melakukan analisis dan interpretasi protokol CAT secara bebas. 


\section{BAB II \\ PENGENALAN KARTU}

\section{Kemampuan Akhir Yang Direncanakan :}

Setelah mempelajari bab ini, diharapkan mahasiswa mampu mengenali kartu-kartu TAT dan CAT, karakteristik masing-masing kartu TAT dan CAT, dan tema-tema yang terungkap dari masingmasing kartu TAT maupun CAT

\section{Pengantar}

Seperti diketahui TAT merupakan tes proyeksi non verbal yang terdiri atas serangkaian gambar, dimana testee diminta untuk membuat cerita tentang apa yang ia yakini sedang terjadi dalam situasi atau kejadian yang dilukiskan dalam gambar-gambar itu. Cerita yang dibuat testee dianggap mampu memaparkan kecenderungan-kecenderungan yang mendasari, yang dihambat, yang tidak mau atau tidak dapat diakui oleh subyek karena ia tidak menyadari tentang itu (Marnat, 2010).

CAT dianggap sebagai salah satu derivate dari TAT. Oleh karena itu, CAT juga merupakan tes proyeksi non verbal. CAT dikembangkan karena TAT dianggap kurang tepat bila digunakan pada anak-anak meskipun TAT awalnya dihapakan bisa digunakan untuk anak-anak (usia 4-14 tahun).

Berikut akan dijelaskan kartu-kartu TAT dengan masing-masing karakteristiknya yang dianggap mampu mengungkap hal-hal seperti dijelaskan di atas. Selanjutnya, akan dijelaskan juga kartukartu CAT beserta karakteristik di masing-masing kartunya dan tema yang mungkin bisa terungkap seperti dijelaskan di atas . 


\section{A. TAT}

\section{Kartu-kartu TAT}

Kartu TAT terdiri dari 30 kartu bergambar yang masingmasing diberi nomer, yang diberi kode atau tidak, seperti terlihat pada tabel di bawah ini

Tabel 2.1

Kartu-kartu TAT

\begin{tabular}{|c|c|c|c|}
\hline no & $\begin{array}{c}\text { Tanpa/dengan } \\
\text { kode }\end{array}$ & Nomer kartu & ggan \\
\hline \multicolumn{2}{|c|}{ a. Tanpa kode } & \begin{tabular}{|l|}
$1,2,4,5,10,11$ \\
$14,15,16,19,20$
\end{tabular} & $\begin{array}{l}\text { Untuk laki-laki mau- } \\
\text { pun perempuan }\end{array}$ \\
\hline \multicolumn{4}{|c|}{ b. Dengan kode } \\
\hline b.1 & B (Boy) & 13B & untuk anak laki-laki \\
\hline b. 2 & M (Male) & $12 \mathrm{M}$ & untuk laki-laki dewasa \\
\hline b.3 & BM (Boy Male) & $\begin{array}{l}\text { 3BM,6BM,7B, } \\
8 \mathrm{BM}, 17 \mathrm{BM} \\
\end{array}$ & $\begin{array}{l}\text { untuk anak laki-laki \& } \\
\text { laki-laki dewasa }\end{array}$ \\
\hline b.4 & G (Girl) & $13 G$ & Untuk anak perempuan \\
\hline b.5 & BG (Boy Girl) & $12 B G$ & $\begin{array}{l}\text { untuk anak laki-laki \& } \\
\text { anak perempuan }\end{array}$ \\
\hline b.7 & F (Female) & $12 \mathrm{~F}$ & $\begin{array}{l}\text { untuk perempuan de- } \\
\text { wasa }\end{array}$ \\
\hline b.8 & GF (Girl Female) & $\begin{array}{l}3 G F, 6 G F, 7 G F \\
8 G F, 9 G F, 17 G F \\
18 G F\end{array}$ & $\begin{array}{l}\text { Untuk anak perem- } \\
\text { puan \& perempuan } \\
\text { dewasa }\end{array}$ \\
\hline b.9 & $\begin{array}{l}\text { MF (Male } \\
\text { Female) }\end{array}$ & $13 \mathrm{MF}$ & $\begin{array}{l}\text { untuk laki-laki dewasa \& } \\
\text { perempuan dewasa }\end{array}$ \\
\hline
\end{tabular}

Catatan : M (laki-laki dewasa), usia di atas 14 tahun; $\mathbf{F}$ (perempuan dewasa), usia di atas 14 tahun juga; B (anaklaki-laki), usia 4 - 14 tahun; G (anak perempuan, usia 4-14 tahun juga (Anastasi, 2007). 
Kartu TAT ada juga yang dibuat untuk tujuan khusus, yaitu untuk mengetahui Motivasi Berprestasi, dibuat oleh McClelland, dan terdiri dari 6 kartu (gambar ada di lampiran)

\section{Karakteristik Kartu-kartu TAT}

Freidenberg (1995) menyebutkan bahwa tidak seperti Rorschach, TAT disusun dari teori dasar tertentu, yaitu Teori Kepribadian Murray. Oleh karena itu, pendekatan teoritisnya digunakan untuk memilih item gambar, dan skor untuk respon yang diberikan testee berdasar teori Murray.

Masing-masing kartu memiliki karakteristik yang dimaksudkan untuk mengungkap tema laten. Respon testee (dalam bentuk cerita) diharapkan mengekspresikan kebutuhan-kebutuhan, harapan-harapan, dan fantasi-fantasi tak sadar (tema laten) testee.

Kartu 1 : Gambar anak laki-laki yang termenung, dan di depannya ada biola di atas meja.

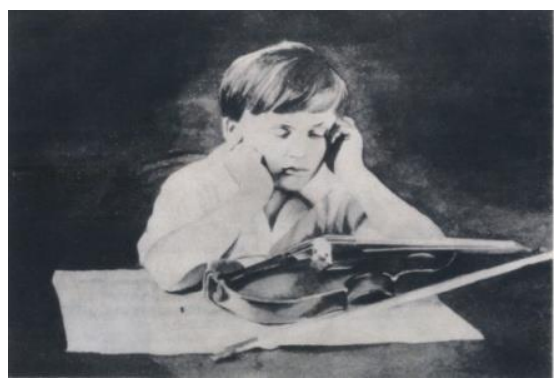

Tema yang bisa diungkap :

- Jika diijinkan menggunakan hanya 1 (satu) kartu, maka Bellak akan memilih kartu ini, karena kartu ini dapat mengungkap gambaran total kepribadian. 
Tema laten kartu ini :

- hubungan anak dengan figur orang tua

- motivasi prestasi, respon seksual (simbolik)

- agresi dengan atau tanpa konotasi seksual

- kecemasan super ego (pertentangan antara doro-ngan hati dengan kontrol diri, antara kehendak sendiri dengan kekuatan budaya di luar diri)

- body image / self image

- kecenderungan obsesi

Kartu 2 : Gambar pemandangan desa. Gambar yang di depan adalah seorang gadis membawa buku, dan di belakangnya gambar seorang pria dewasa yang bekerja di ladang, serta seorang wanita tua yang sedang memperhatikan si pria itu.

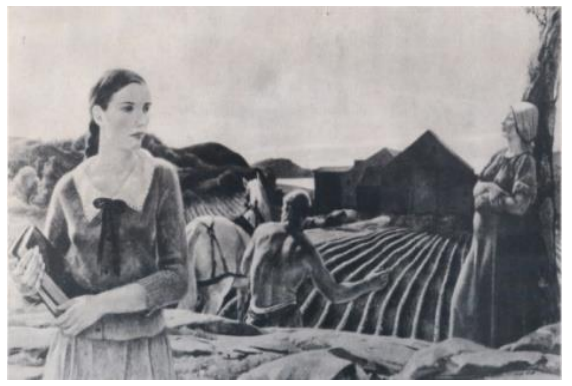

Tema laten kartu ini adalah :

- hubungan keluarga

- kehamilan (termasuk sikap terhadap orang tua)

- homoseksual

- Otonomi

- kecenderungan kompulsi

- Compliance (kepatuhan) 
- peran seksual

- Oedipal

- aspirasi, ambisi, mobilitas pribadi

- sibling rivalry

- pandangan terhadap lingkungan

- pandangan terhadap tradisi, apakah tradisi diang-gap penting atau dianggap menghambat

Kartu 3 BM: Seorang anak lelaki dengan kepala yang ditelungkupkan di atas tangan kanannya duduk di lantai, di sampingnya ada senjata tergeletak di lantai.

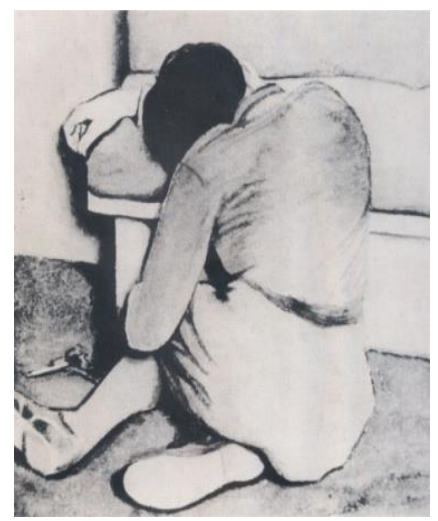

Tema laten dari kartu ini adalah :

- homo seksual laten

- depresi

- agresi (terutama karena frustrasi)

- patah hati

- asosiasi terhadap kehilangan

- perasaan bersalah 
- sikap terhadap diri yang terisolir

Kartu 3 GF : Seorang gadis berdiri dengan menundukkan kepalanya, dan wajahnya ditutup dengan tangan kanannya. Tangan kirinya berpegangan pintu kayu.

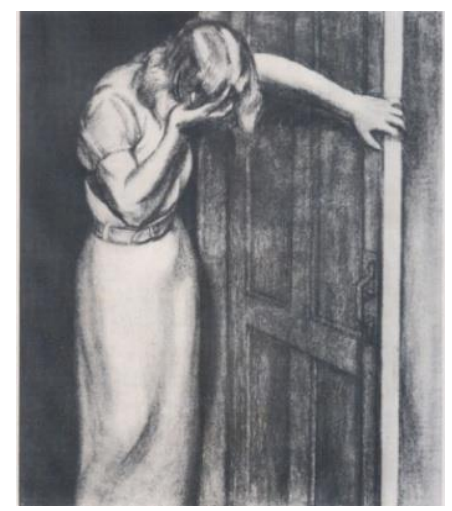

Dibandingkan dengan kartu 3 GF, maka kartu 3 BM lebih bermanfaat, dan testee lebih mudah melakukan identifikasi.

Tema laten kartu ini :

- perasaan depresi

- kesedihan

- putus asa

- konflik

- cara pertahanan yang berbentuk pasif atau asertif

Kartu 4 : Seorang wanita yang memegang bahu seorang pria yang berhadapan dengannya, dan pria itu memalingkan tubuhnya, seolah-olah ia menarik dirinya dari wanita tersebut. 


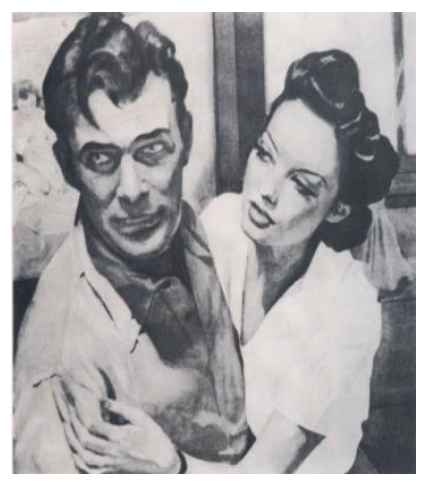

Tema laten dari kartu ini_adalah :

- hubungan pria - wanita

- kelompok minoritas (terutama wanita)

- ketidaksetiaan

- masalah seksual

- sikap pria terhadap peran wanita

- cinta segitiga

- agresi

- konflik antara wanita dan pria

Kartu 5 : Seorang ibu tengah baya yang berdiri di ambang pintu yang setengah terbuka dan melihat ke dalam kamar.

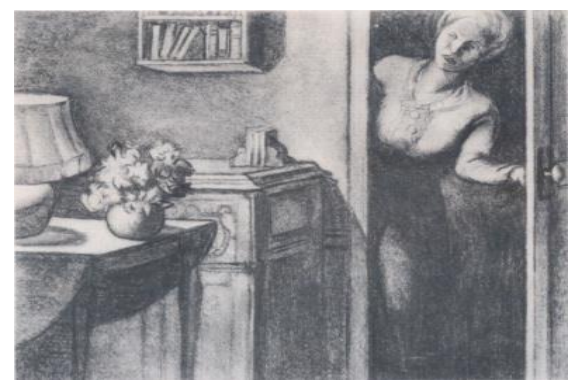


Tema latennya :

- ibu yang sedang memperhatikan aktivitas yang berbeda (merupakan simbolik dari masturbasi yang manifest)

- ibu yang sedang memperhatikan anaknya (voyeuristik)

- ketakutan diserang

- fantasi penyelamatan (dalam arti psikoloanalisis)

- sikap terhadap ibu/istri (dalam hal larangan dan pengawasan)

- sikap terhadap diri sendiri.

Kartu 6BM : Wanita tua berdiri dan di belakangnya ada seorang pria muda. Pria muda itu memandang ke bawah dengan ekspresi bingung atau terkejut.

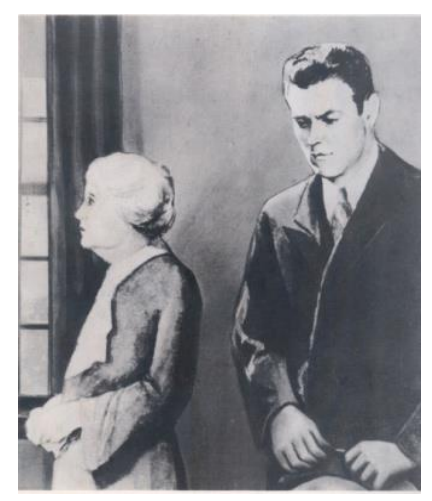

Tema latennya :

- tentang hubungan anak laki-laki dengan ibunya atau derivatnya

- penyebab konflik antara laki-laki - wanita

- penyebab konflik anak laki-laki dengan ibunya (terutama dalam hal perpisahan atau perbedaan pendapat, atau sikap terhadap ibu yang tradisional dan enggan berubah) 
- tema oedipal.

Kartu 6 GF : Seorang wanita muda yang duduk di sofa menengok ke belakang ke arah seorang pria tua dengan pipa di mulutnya.

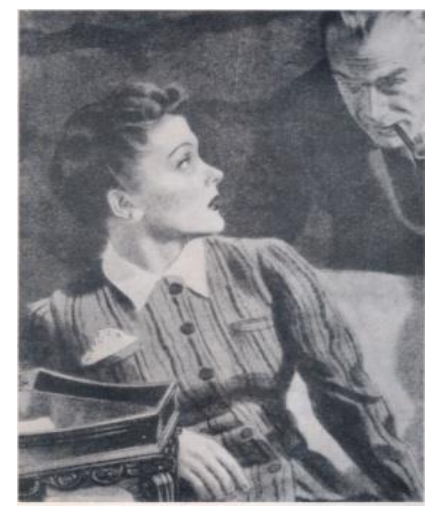

Tema latennya :

- hubungan antara anak wanita dengan ayahnya,

- penyebab konflik antara laki-laki -wanita,

- ayah dengan anak perempuannya,

- pria itu tampak sebagai orang yang sebaya dengan wanita tersebut, yang berkualitas sebagai agresor, pengganggu, dan mengajak untuk menikah

Kartu 7BM : Seorang pria yang memperhatikan seorang pria muda yang sedang mengernyitkan dahi dan melihat pada satu tempat. 


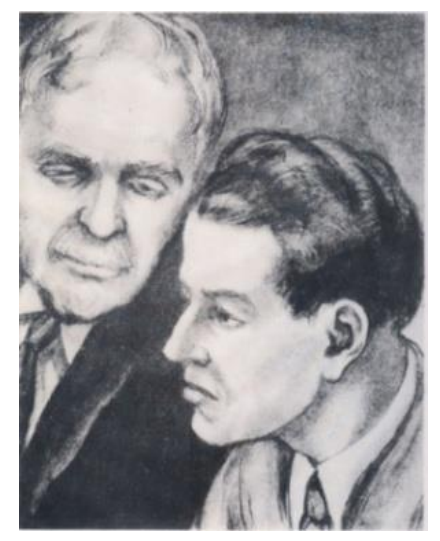

Tema laten dari kartu ini :

- hubungan ayah dengan anak laki-lakinya, serta derivatnya.

Kartu 7GF : Seorang wanita tua sedang duduk di sofa berdekatan dengan seorang anak perempuan. Wanita tersebut berbicara atau membaca buku untuk anak perempuan tersebut. Si anak memegang boneka dan melihat ke tempat yang jauh.

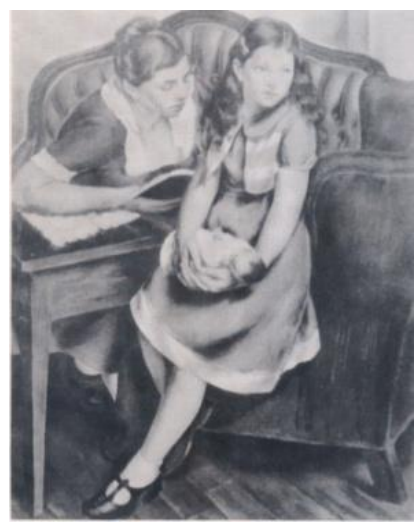




\section{Tema latennya :}

- hubungan antara ibu dengan anak perempuannya dan tampaknya anak tersebut mempunyai sikap negatif (penolakan) kepada ibunya

- sikap terhadap anak yang diharapkan

- sifat-sifat perempuan yang lebih tua dalam lingkungan anak

Kartu 8 BM : Seorang remaja laki-laki yang memandang lurus ke depan. Tong tempat senapan tampak pada satu sisi, dan gambar latar belakang adalah peristiwa berlangsungnya operasi bedah, seperti angan-angan.

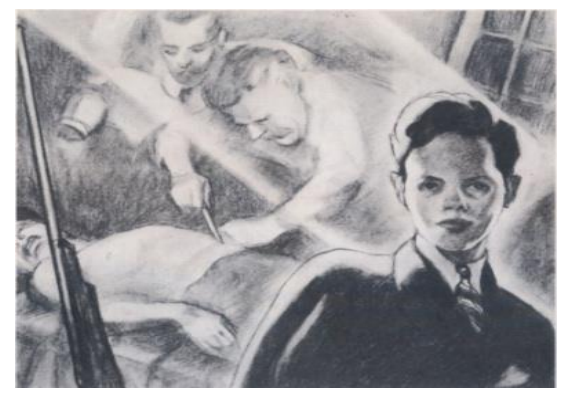

Tema latennya :

- kecenderungan agresi (pembunuhan, dendam, dll.)

- ambisi (mengarah pada hal positif / cita-cita).

Kartu 8 GF : Seorang wanita muda duduk dengan bertopang dagu, dan melihat ke tempat jauh. 


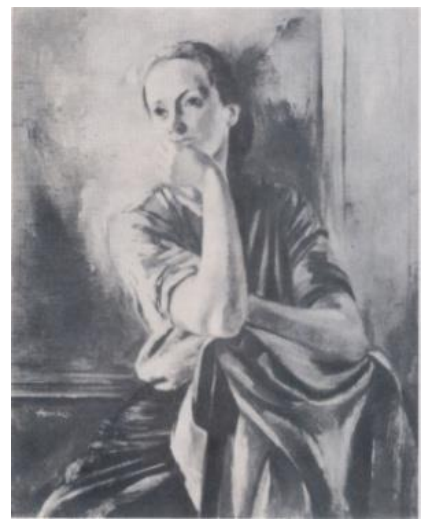

Menurut Bellak, kartu ini kurang bermanfaat.

Tema latennya adalah :

- Ambisi tentang masa sekarang (dalam kehidupan keluarga)

- Lamunan positif tentang masa depan (perkawinan, rumah tangga)

- Orientasi terhadap diri sendiri

Kartu 9 BM : Empat pria berbaring di rumput dengan santainya.

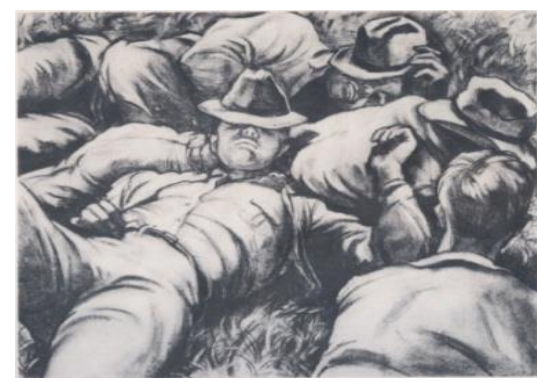

Tema laten kartu ini adalah :

- hubungan dengan teman sebaya 
- dorongan \& ketakutan homoseksual

- pria dengan pria

- hubungan sosial

- prasangka sosial

Kartu 9 GF : Seorang gadis membawa majalah dan dompet. Di belakang pohon ada gadis lain dengan pakaian pesta lari sepanjang pantai.

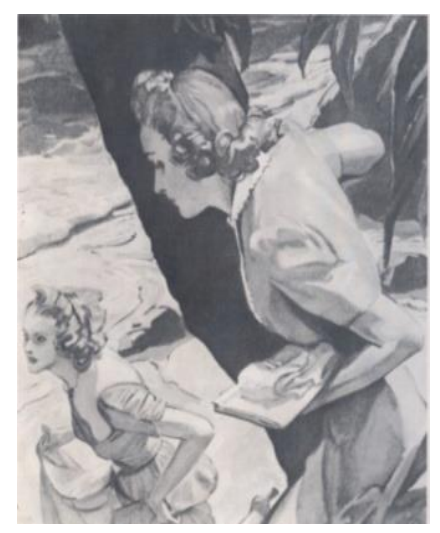

Tema latennya adalah :

- hubungan wanita dengan wanita,

- depresi,

- sister rivalry,

- kecenderungan bunuh diri,

- permusuhan antara ibu dan anak gadisnya,

- paranoia.

- Seringkali figur pria dikenalkan dalam gambar ini, dan pria itu bersifat mesra atau agresi berkonotasi seksual. 
Kartu 10 : Seorang gadis dengan kepala bersandar pada bahu seorang pria.

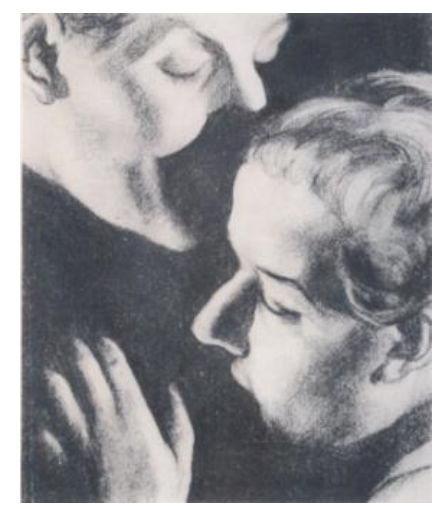

Tema laten dari kartu ini :

- hubungan intim antara pria dan wanita

- pertemuan untuk berpisah atau kedatangan

- homoseksual laten (jika respon ceritanya tentang hubungan pria dengan pria atau wanita dengan wanita)

- hubungan antara anak dengan orang tua

Kartu 11 : Sebuah jalan menyusuri jurang yang dalam dengan karang yang terjal. Di jalan yang jauh tampak ada figur yang tidak jelas. Dari salah satu sisi dinding karang yang menonjol tampak leher dan kepala panjang seekor naga.

Tema laten kartu ini :

- ketakutan infantile/primitive

- kekuatan supranatural

- ketakutan diserang

- rasa ingin tahu yang besar akanhal

- hal yang berbahaya / mengancam 
- agresi oral

- kemampuan menangani saat tidak ada dukungan manusia lain

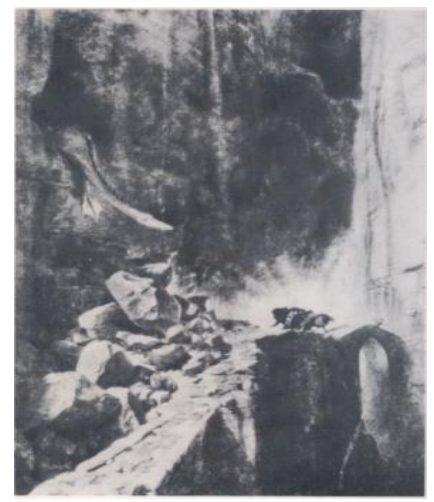

Kartu 12 M : Seorang pria muda berbaring dengan mata tertutup, dan di depannya berdiri condong kepadanya seorang pria lebih tua yang kurus. Pria tua itu mengulurkan tangannya di atas wajah pria muda.

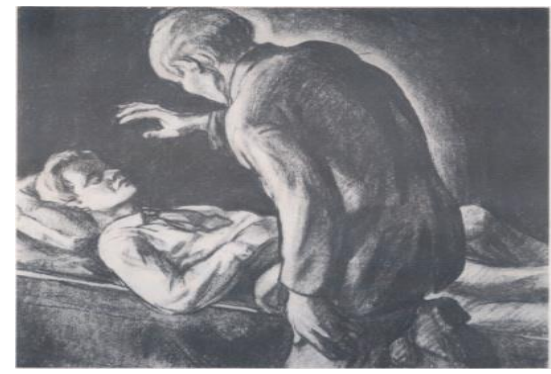

Tema latennya :

- hubungan pria muda dengan pria tua

- ketakutan homoseksual pasif 
- hubungan antara ayah - anak

- ketakutan akan dominasi figur yang lebih dominan

- hubungan antara kakak - adik sesama jenis

- kepasifan seseorang

Kartu 12 F : Gambar seorang wanita muda. Di belakangnya ada seorang wanita tua yang aneh/mengerikan dengan syal di kepalanya dan menyeringai.

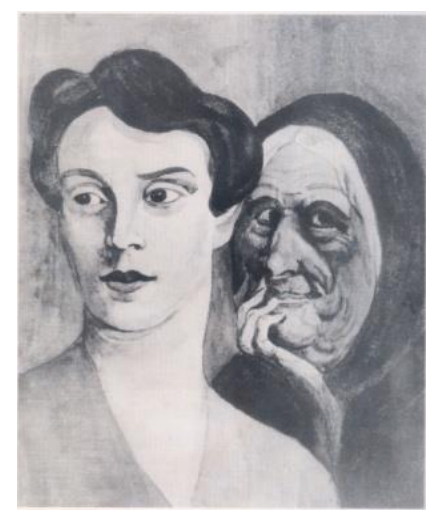

Tema latennya adalah :

- konsep tentang figur ibu

- hubungan antara ibu - anak perempuannya

- seringkali tentang ibu mertua

- ketakutan akan dominasi figur yang lebih tua

- adanya ancaman masa tua

Kartu 12 BG : Perahu dayung di tepi sungai di hutan, dan tidak ada gambar orang 


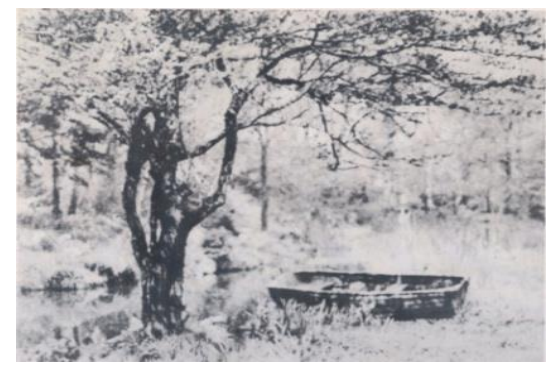

Tema laten dari kartu ini :

- kecenderungan bunuh diri

- depresi

- kecemasan / ketakutan anak

- kebutuhan menikmati ketenangan

- ungkapan kebutuhan akan kehadiran manusia atau tidak Menurut Bellak, kartu ini kurang bermanfaat, kecuali untuk kasus yang sesuai dengan tema laten-nya. Seringkali, respon cerita kartu ini adalah seseorang yang meloncat atau jatuh dari perahu.

Kartu 13 MF : Seorang pria muda berdiri dengan sedih dan tangannya menutupi kepalanya. Di belakangnya ada seorang wanita berbaring di dipan.

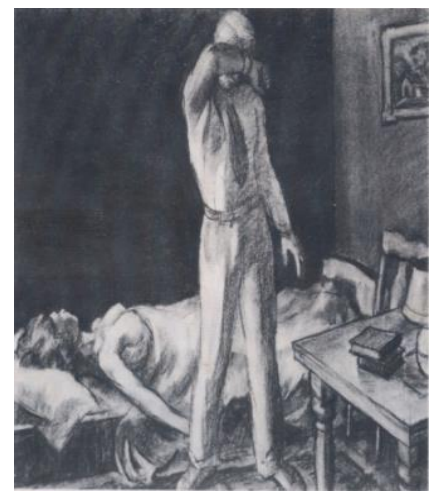


Tema latennya adalah :

- tentang konflik seksual antara pria dan wanita

- dengan figur wanita seringkali ditonjolkan cerita tentang ketakutan dirampok, diserang, disiksa oleh pria

- Sedangkan figur pria sering menunjukkan perasaan bersalah karena aktivitas seksual, homoseksual

- Seringkali muncul cerita tentang deprivasi ekonomi

- Sikap terhadap pasangan hubungan seksual, ter-utama reaksi sebelum atau sesudah hubungan seksual

- obsesi-kompulsi

- hubungan antara nafsu seks dengan perasaan agresi

Kartu 13 B : Anak laki-laki duduk di pintu masuk pondok kayu.

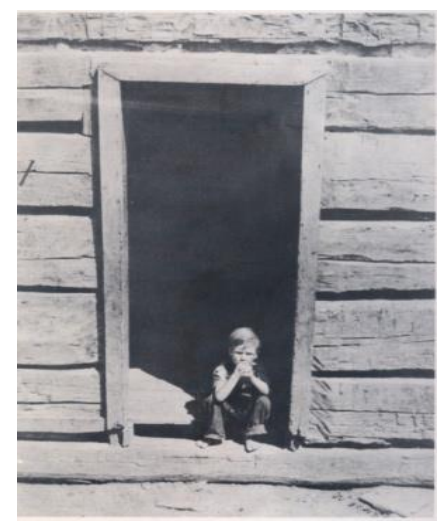

Tema laten dari kartu ini :

- cerita tentang masa kanak-kanak

- adanya perasaan tidak berarti, sendiri

- perasaan kesepian 
Kartu 13 G : Seorang anak perempuan sedang berjalan naik tangga suatu bangunan.

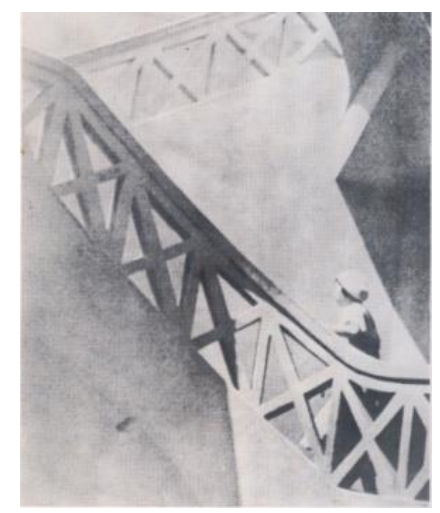

Menurut Bellak, kartu ini kurang bermanfaat, tetapi adakalanya mengungkap adanya perlakuan yang mengenai perasaan, diliputi kecemasan.

Kartu 14 : Bayangan hitam seorang pria (wanita) di jendela.

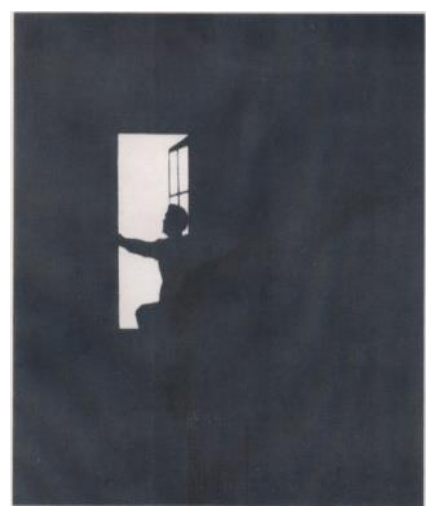

Tema laten dari kartu ini :

- tentang identifikasi seksual

- ketakutan terhadap gelap pada masa kanak-kanak 
- harapan, perencanaan masa depan

- cerminan masalah yang sedang dihadapi klien

- ambisi

- kecenderungan bunuh diri

- pencuri yang datang

Kartu 15 : Pria yang kurus dengan menggenggam tangannya berdiri di atas nisan.

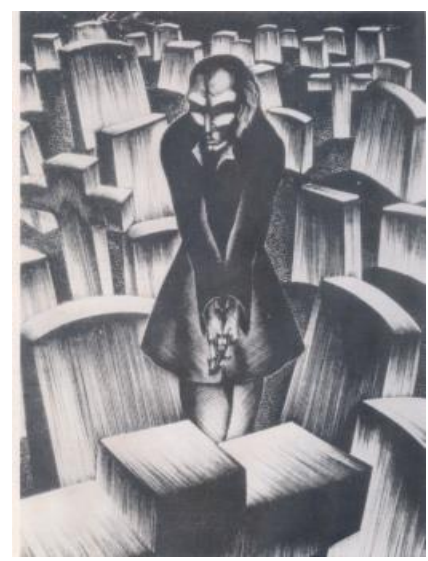

Tema laten :

- tentang kematian keluarga terdekat(orang yang dicintai)

- kecenderungan depresi

- ketakutan akan kematian

- pengalaman masa lalu / sekarang

Kartu 16 : Kartu kosong.

Menurut Bellak, kartu ini kurang bermanfaatdan kurang mempunyainilai (value)

Tema laten yang ada :

- masalah yang menekan pikiran klien 
- ambisi / harapan yang sedang atau akan dicapai

Kartu 17 BM : Pria dengan busana minim dan berpegangan tali, dalam aktivitas turun dan naik.

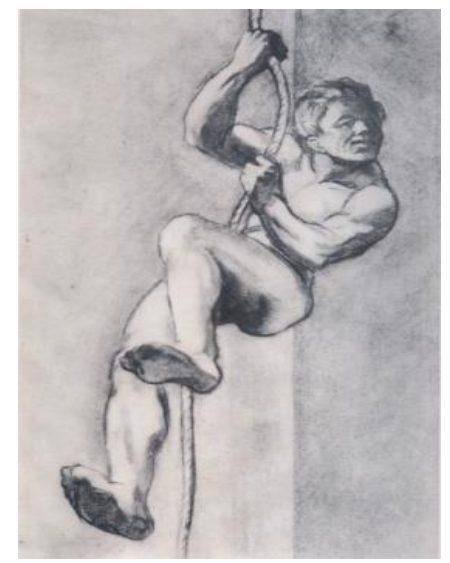

Tema laten dari kartu ini :

- ketakutan oedipal

- adanya masalah atau konflik yang belum dapat diatasi

- perasaan homoseksual

- reaksi terhadap keadaan darurat / mendesak (melarikan diri)

- body image

- keinginan untuk menonjolkan diri (narsistik, ekshibitionistik)

Kartu 17 GF : Sebuah jembatan di atas sungai, dan seorang wanita bersandar pada pagar jembatan tersebut. Di belakang tampak sebuah bangunan dan gambar kecil seorang pria. 


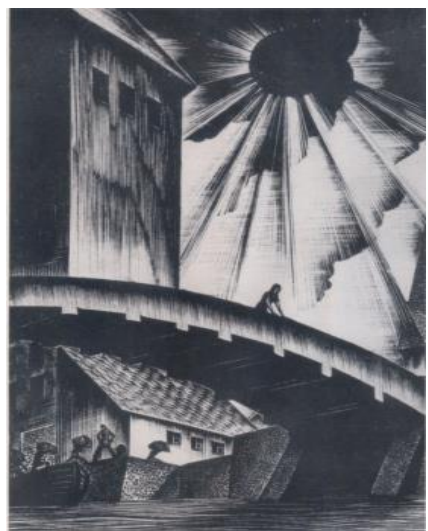

Tema latennya :

- kecenderungan bunuh diri pada wanita

- lesbian

- perasaan depresi yang memunculkan sikap agesif

- kriminalitas

Kartu 18 BM : Seorang pria dicengkeram tiga tangan dari belakang.

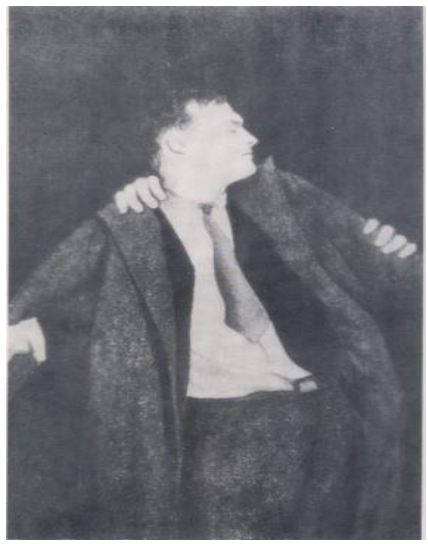


Tema latennya :

- kecemasan pada pria

- indikasi kecanduan obat / alkohol

- ketakutan diserang pada homoseksual

- adanya masalah atau konflik yang belum dapat diatasi

- kecemasan terhadap agresi

- nasib malang

Kartu 18GF : Seorang wanita dengan tangan mendekap tenggorokan anita lain, yang tampaknya terdesak di balik sandaran tangga.

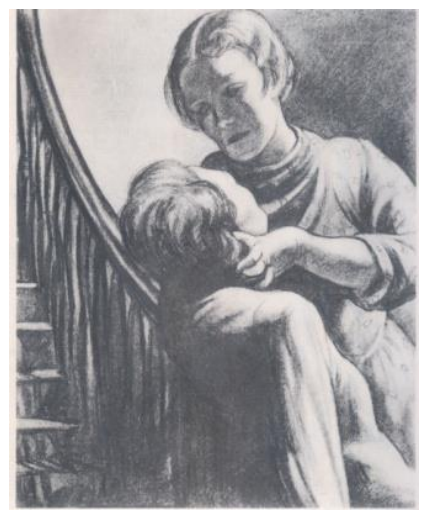

Tema laten dari kartu ini :

- agresi yang dilakukan oleh wanita

- konflik ibu dengan anak perempuannya

Kartu 19 : Gambar aneh tentang bentuk awan tergantung di atas pondok yang tertutup salju di sebuah desa. 


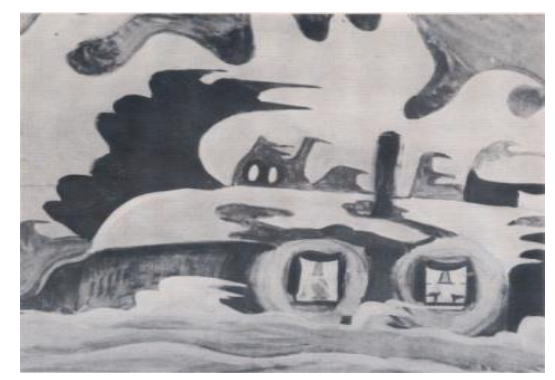

Tema latennya :

- Keinginan akan rasa aman

- Cara-cara mengatasi frustrasi yang ditimbulkan oleh lingkungan

- Kemampuan didalam menghadapi hal-hal baru dan luar biasa

Catatan :

Orang yang berpikir stereotipe atau yang memiliki rasa tidak aman sering menolak kartu ini, dengan mengatakan kartu ini sebagai karya seni yang jelek atau menyeramkan, atau sama sekali menolak memberikan tanggapan (Sukadji, 1982).

Kartu 20 : Figur pria atau wanita bersandar pada tiang lampu di remang-remang cahaya pada malam yang sunyi.

Tema latennya adalah :

- ketakutan terhadap pria atau gelap (pada testee wanita)

- ketakutan pada penjahat (pada pria dan wanita)

- Masalah / konflik yang sedang dihadapi klien

- Masalah dengan lawan jenis

- Adanya kecenderungan agresivitas

- cerita tentang hal-hal yang berbahaya di malam hari 
- perasaan kesepian, ragu-ragu

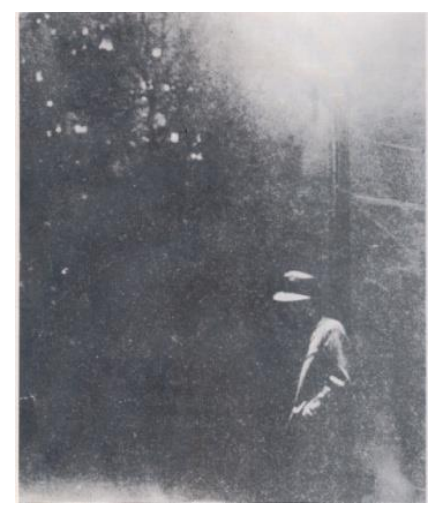

\section{B. CAT}

\section{Kartu-kartu CAT dan Karakteristiknya}

Kartu CAT hanya terdiri dari 10 kartu, karena pada dasarnya anak-anak mempunyai rentang perhatian terbatas sehingga mereka hanya bisa fokus bila kartu yang diberikan lebih sedikit.

Kartu CAT memiliki beberapa variasi, yaitu CAT original yang disusun oleh Leopold Bellak dan Sonya Sorel Bellak, CAT-A.I (CAT-Adaptasi Indonesia) dan CAT-H (CAT-Human), dan CAT-S (CAT-Supplement). Baik CAT-A.I maupun CAT-H, masing masing terdiri dari 10 kartu yang memiliki esensi gambar dalam situasi yang sama hanya berbeda pada tokoh ceritanya.

Di bawah ini akan dijelaskan kartu CAT original beserta karakteristik dan tema yang terungkap. Sedangkan gambar kartu CAT-A.I dan CAT-H ada di halaman lampiran. 
Kartu 1 : Tiga anak ayam duduk mengelilingi sebuah meja yang dengan tempat nasi di atasnya, dan ada ayam dewasa muncul di latar belakang yang tergambar samar-samar.

Tema yang terungkap :

1. "sibling rivalry" (persaingan antar saudara)

2. Situasi pemberian hadiah atau pemberian hukuman (lewat situasi pemberian makan oleh orang tua)

3. Masalah umum yang berkaitan pemuasan kebutuhan oral Gambar kartu 1 seperti di bawah :

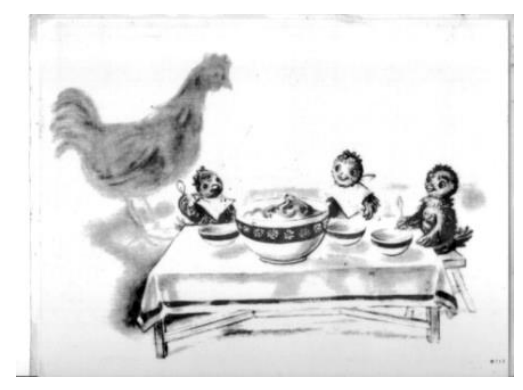

Kartu 2 : Beruang besar dan bayi beruang bermain tarikmenarik tali.

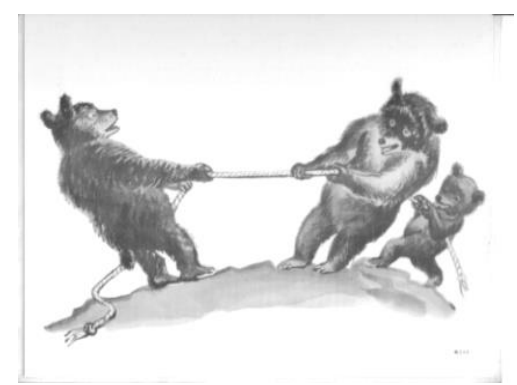


Tema yang terungkap :

1. Tentang identifikasi anak terhadap figur yang dapat diajak bekerjasama di antara ayah atau ibu

2. Masalah yang berkaitan dengan ketakutan akan agresi

3. Sikap agresi anak (terhadap orang dewasa) atau otonomi

4. Tarik-menarik diibaratkan sebagai simbol defense mechanism, dan tali dianggap simbol masturbasi

Kartu 3 : Singa duduk di atas kursi takhta sambil merokok diawasi oleh tikus melalui sebuah lubang.

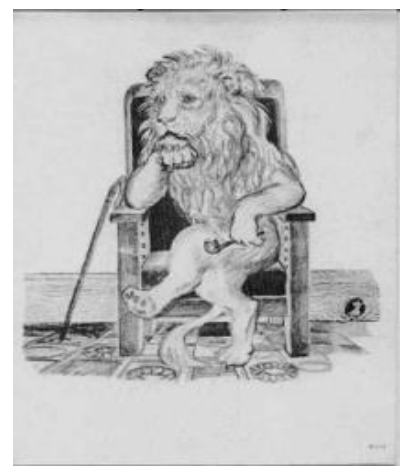

Tema yang terungkap :

1. Persepsi anak tentang figur ayah yang dilengkapi simbol pipa dan tongkat (apakah ayah seseorang yang kuat, gagah, tidak berdaya, dII). Singa dianggap mewakili figur ayah bagi anak.

2. Tikus dipandang sebagai anak-anak, namun beberapa anak mengidentifikasi diri mereka dengan singa dan mengganti figur identifikasi beberapa kali. Hal ini menunjukkan kebingungan identifikasi peran, konflik antara pemenuhan kebutuhan dan otonomi 
Kartu 4 : Seekor kangguru memakai topi, membawa keranjang berisi botol susu, dikantongnya ada anak kangguru yang sedang memegang balon, sedangkan anak kangguru yang lebih besar sedang mengendarai sepeda.

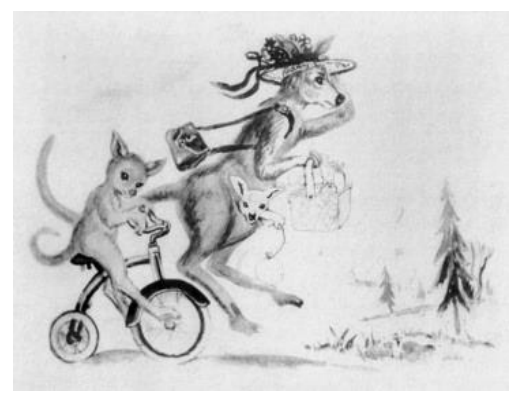

Tema yang terungkap :

1. "sibling rivalry"

2. Hubungan antara ibu-anak

3. Keinginan untuk mandiri dan berkuasa

4. Apabila anak mengidentifikasi pada anak kanguru yang digendong ada indikasi regresi.

Kartu 5 : Sebuah kamar yang gelap dengan tempat tidur besar pada latar belakang, dan di latar depan ada tempat tidur bayi dengan 2 bayi beruang di dalamnya.

Tema yang terungkap :

1. Keingintahuan anak tentang seks

2. Keingintahuan anak tentang kenikmatan

3. Ketakutan dan ketergantungan 
Gambar kartu 5 seperti di bawah :

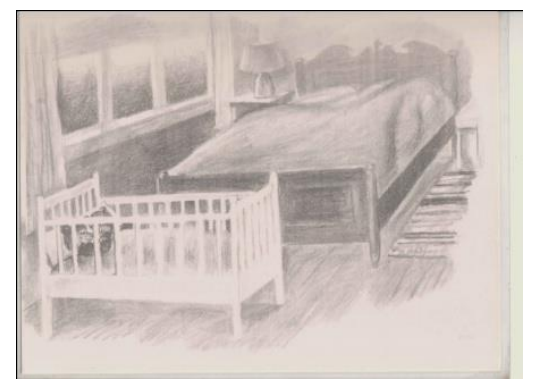

Kartu 6 : Sebuah gua yang gelap di mana dua beruang besar di latar belakang, dan disamping berbaring seekor bayi beruang.

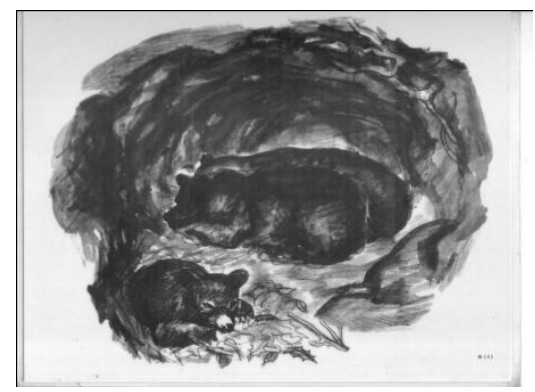

Tema yang terungkap :

1. Identifikasi terhadap sikap orang tua

2. Merefleksikan perasaan cemburu

3. Kecemasan dan ketakutan berpisah dengan orang tua 
Kartu 7 : Seekor harimau ganas menunjukkan taring dan cakarnya melompat ke arah monyet yang mencoba melompat ke arah pohon.

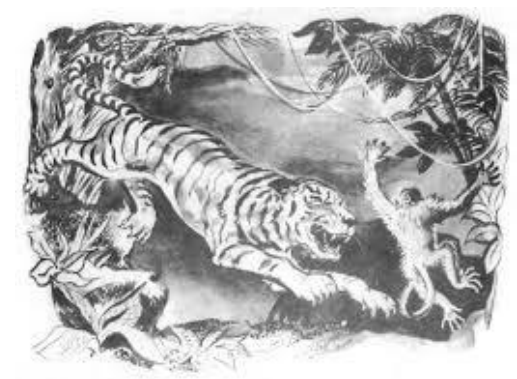

Tema yang terungkap :

1. Tingkat kecemasan anak yang berkaitan dengan adanya agresi dan keinginan mengalahkan saingan

2. Apabila dalam bercerita memenangkan harimau (kera kalah) merupakan proyeksi, yang berarti kera kalah karena kera mempunyai kesalahan

3. Sedangkan dalam cerita subjek kera yang menang (berhasil menghindarkan diri) merupaka proyeksi mampu melepaskan diri dari bahaya

Kartu 8 : Dua monyet dewasa duduk di sofa, sementara monyet dewasa lain sedang berbicara dengan bayi monyet.

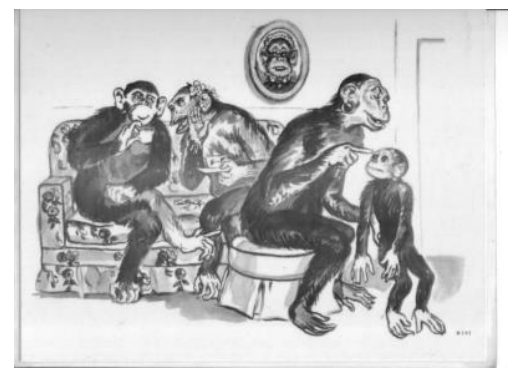


Tema yang terungkap :

1. Berkaitan dengan peran anak di dalam keluarga.

2. Konsep anak mengenai kehidupan sosial orang dewasa, suasana keluarga, hubungan antar anggota keluarga, bagaimana anak menempatkan dirinya dalam keluarga dan lingkungan.

Kartu 9 : Sebuah kamar terdapat tempat tidur anak-anak, dan seekor kelinci duduk sambil memandang ke arah pintu.

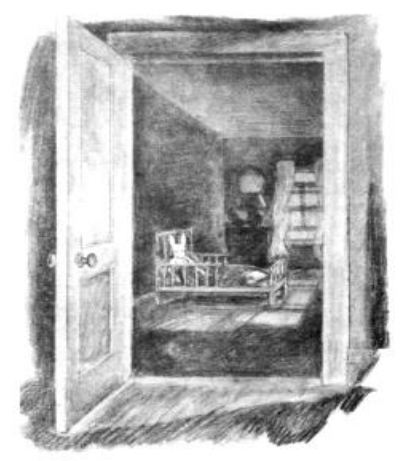

Tema yang terungkap :

1. Ketakutan akan kegelapan, ditinggal sendiri, dipisahkan oleh orang tua

2. Rasa ingin tahu yang besar mengenai sesuatu hal yang terjadi

3. Keinginan anak mengetahui situasi di luar kamar

4. Untuk mengetahui mutu hubungan anak dengan saudara-saudaranya atau dengan lingkungan 
Kartu 10 : Seekor anak anjing yang dipukul oleh anjing dewasa di depan kamar mandi.

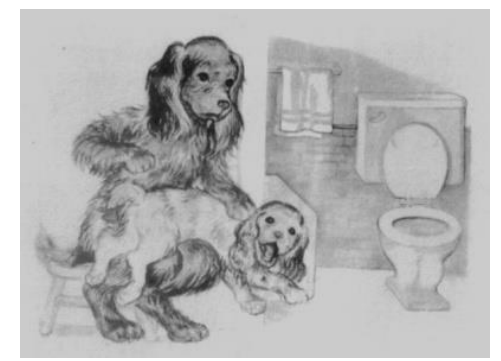

Tema yang terungkap :

1. Konsep moral anak ("kejahatan dan hukuman")

2. Sikap terhadap saudara, misal : iri hati, merasa tidak adil

3. "toilet- training"

4. Kecenderungan regresi

5. Identifikasi latihan dan kedisiplinan terhadap anak. 


\section{BAB III \\ ADMINISTRASI TES}

\section{Kemampuan Akhir Yang Direncanakan :}

Setelah mempelajari bab ini, diharapkan mahasiswa mampu memahami Persiapan tes dan mampu melaksanakan tes TAT maupun CAT

\section{A. TAT}

1. Hal-hal Yang Harus Diperhatikan

Idealnya, ada banyak hal yang harus diperhatikan dan dipersiapkan sebelum menggunakan TAT, baik untuk mengungkap kepribadian individu atau untuk tujuan lain.

a. Persyaratan umum psikodiagnostik agar testing di katakan valid harus diperhatikan :
1) kesiapan tester
2) rapport yang baik
3) kondisi tempat
4) atmosfir ruang tes
5) kondisi testee

b. Sebelum memberikan tes TAT, perlu diperoleh dulu identitas testee secara jelas, seperti :

1) jenis kelamin.

2) usia,

3) tingkat pendidikan,

4) jumlah saudara,

5) nomer urut testee dalam keluarga,

6) hubungan dengan saudara,

7) identitas orang tua,

8) hubungan ayah dan ibu,

9) hubungan dengan teman spesial atau sahabat,

10) taraf kecerdasan (tidak harus tes inteligensi), 
11) kesehatan psikologisnya,

12) permasalahan testee.

c. Tester perlu melakukan konseling awal untuk mendalami permasalahan testee.

d. Disamping itu perlu diberi tes lain seperti tes grafis atau tes Rorschach, karena TAT merupakan tes suplemen bagi kedua tes tersebut, dan TAT akan membantu menerangkan hasil dari tes grafis atau Rorschach. TAT dapat dilaksanakan secara individual, self administration, dan kelompok.

\section{Tahap Persiapan}

a. Melakukan rapport dengan baik

1) Menanyakan keadaan testee

2) Menyesuaikan diri dengan individualitas testee

3) Membuat suasana tidak tegang, agar testee mudah, bebas, nyaman untuk mengutarakan imajinasinya berupa cerita (verbal) maupun ekspresi emosinya.

4) Menerima klien tanpa kritik,

5) Tidak mengadili, dan

6) Menciptakan kepercayaan bahwa rahasianya terjamin.

b. Penentuan kartu mana yang akan digunakan berdasarkan :

1) Tujuan pengetesan :

apakah untuk mengungkap kepribadian, penanganan kasus, dan lain lain.

2) Jenis kelamin testee:

(a) Untuk laki-laki kartu yang bisa diberikan :

\begin{tabular}{|c|c|l|c|}
\hline \multicolumn{3}{|c|}{ Kartu tanpa kode, yaitu kartu nomer: } \\
\hline \multicolumn{3}{|c|}{$1,2,4,5,10,11,14,15,16,19,20}$. \\
\hline \multicolumn{3}{|c|}{ Kartu dengan kode } & yaitu kartu nomer \\
\hline 1 & $\mathrm{M}$ & laki-laki dewasa & $12 \mathrm{M}$ \\
\hline 2 & $\mathrm{BM}$ & anak laki-laki \& & $3 \mathrm{BM}, 6 \mathrm{BM}, 7 \mathrm{BM}$, \\
\hline
\end{tabular}




\begin{tabular}{|c|l|l|l|}
\hline & & laki-laki dewasa & $\begin{array}{l}\text { 8BM, 9BM, 17BM, } \\
18 \mathrm{BM}\end{array}$ \\
\hline 3 & BG & $\begin{array}{l}\text { anak laki-laki \& } \\
\text { anak perempuan }\end{array}$ & $12 \mathrm{BG}, 13 \mathrm{~B}$ \\
\hline 4 & MF & $\begin{array}{l}\text { anak perempuan } \\
\text { \& wanita dewasa }\end{array}$ & $13 \mathrm{MF}$ \\
\hline
\end{tabular}

(b) Untuk perempuan, kartu yang bisa diberikan :

\begin{tabular}{|c|c|c|c|}
\hline \multicolumn{4}{|c|}{ Kartu tanpa kode, yaitu kartu nomer: } \\
\hline & \multicolumn{3}{|c|}{$1,2,4,5,10,11,14,15,16,19,20$} \\
\hline \multicolumn{3}{|c|}{ Kartu dengan kode } & yaitu kartu nomer \\
\hline 1 & $\mathrm{~F}$ & wanita dewasa & $12 \mathrm{~F}$ \\
\hline 2 & GF & $\begin{array}{l}\text { anak perempuan } \\
\text { \& wanita dewasa }\end{array}$ & $\begin{array}{l}3 \mathrm{GF}, 6 \mathrm{GF}, 7 \mathrm{GF}, 8 \mathrm{GF}, 9 \\
\mathrm{GF}, 17 \mathrm{GF}, 18 \mathrm{GF}\end{array}$ \\
\hline 3 & BG & $\begin{array}{l}\text { anak laki-laki \& } \\
\text { anak perempuan }\end{array}$ & $12 \mathrm{BG}, 13 \mathrm{G}$ \\
\hline 4 & MF & $\begin{array}{l}\text { anak perempuan } \\
\text { \& wanita dewasa }\end{array}$ & $13 \mathrm{MF}$ \\
\hline
\end{tabular}

3) Berapa hari pelaksanaan tes bisa dilakukan :

(a) Jika semua kartu disajikan, maka pelaksanaannya harus 2 (dua) hari yaitu :

- Hari pertama : kartu no. 1 s/d 10, sedangkan

- Hari kedua : kartu no 11 s/d 20.

(b) Pada kondisi dimana kita hanya mempunyai 1 (satu) hari pelaksanaan, karena :

1) untuk tujuan "saving time" dan interpretasi, maka paling banyak yang bisa diberikan 10-12 kartu gambar TAT.

2) untuk penanganan kasus, ditambah 1,2, atau 3 gambar lain sesuai dengan kasusnya. 
Ada pilihan versi kartu yang bisa diberikan :

a. Untuk laki-laki :

\begin{tabular}{|c|l|l|}
\hline no & versi & nomer kartu \\
\hline 1 & Klopfer & $\begin{array}{l}1,2,3 \mathrm{BM}, 4,9 \mathrm{BM}, 11,12 \mathrm{M}, \\
13 \mathrm{MF}, 15,16,18 \mathrm{BM}\end{array}$ \\
\hline 2 & Holt & $\begin{array}{l}1,2,3 \mathrm{BM}, 4,9 \mathrm{BM}, 11,12 \mathrm{M}, \\
13 \mathrm{MF}, 15,16,18 \mathrm{BM}\end{array}$ \\
\hline 3 & Levinson & $\begin{array}{l}2,3 \mathrm{BM}, 4,6 \mathrm{BM}, 7 \mathrm{BM}, 12 \mathrm{M}, \\
13 \mathrm{MF}, 14,15,16,18 \mathrm{BM}\end{array}$ \\
\hline 4 & Watson & $\begin{array}{l}1,3 \mathrm{BM}, 4,6 \mathrm{BM}, 7 \mathrm{BM}, 8 \mathrm{BM}, 12 \mathrm{M}, \\
13 \mathrm{MF}, 16,18 \mathrm{BM}, 20\end{array}$ \\
\hline 5 & Bellak & $\begin{array}{l}1,2,3 \mathrm{BM}, 4,6 \mathrm{BM}, 7 \mathrm{BM}, 11, \\
12 \mathrm{M}, 13 \mathrm{MF}\end{array}$ \\
\hline
\end{tabular}

b. Untuk perempuan :

\begin{tabular}{|c|l|l|}
\hline no & versi & nomer kartu \\
\hline 1 & Klopfer & $\begin{array}{l}\text { 3BM, 4, 9GF, 11, 12F, 13MF, 15, } \\
16,18 \mathrm{GF}\end{array}$ \\
\hline 2 & Holt & $\begin{array}{l}1,3 \mathrm{BM}, 4,5,7 \mathrm{GF}, 8 \mathrm{GF}, 9 \mathrm{GF}, 10, \\
13 \mathrm{MF}, 15,17 \mathrm{GF}, 18 \mathrm{GF}\end{array}$ \\
\hline 3 & Levinson & $\begin{array}{l}2,3 \mathrm{BM}, 4,6 \mathrm{GF}, 12 \mathrm{~F}, 13 \mathrm{MF}, 14, \\
15,16,18 \mathrm{GF}, 20\end{array}$ \\
\hline 4 & Watson & $\begin{array}{l}1,2,3 \mathrm{GF}, 4,7 \mathrm{GF}, 12 \mathrm{~F}, 13 \mathrm{MF}, 16, \\
18 \mathrm{GF}\end{array}$ \\
\hline 5 & Bellak & $\begin{array}{l}1,2,3 \mathrm{BM}, 4,6 \mathrm{GF}, 7 \mathrm{GF}, 9 \mathrm{GF}, 11, \\
13 \mathrm{MF}\end{array}$ \\
\hline
\end{tabular}

4) Pencatatan data (cerita) testee saat pelaksanaan tes

(a) Manual Recording:

- Tester mencatat sendiri data (+ cerita testee) pada kertas

- kelebihan : hemat biaya.

- kelemahan : (1) tester tidak dapat melihat ekspresi testee, (2) ada kemungkinan ada kata- 
kata yang tidak tercatat, (3) testee bisa merasa kurang nyaman karena tester mencatat setiap perkataannya.

(b) Self Recording:

- Testee sendiri yang mencatat ceritanya

- kelebihan : tester dapat mengobservasi ekspresi testee pada saat bercerita.

- kelemahan : kemungkinan tidak muncul ekspresi emosi testee, dan cerita yang muncul tidak spontan karena sibuk mencatat.

(c) Stenografi :

- Tester mencatat dengan menggunakan singkatan atau simbol-simbol secara cepat.

(d) Machine Recording :

- Tester menggunakan tape recorder atau video

- kelebihan : tester dapat memperhatikan ekspresi testee sambil mendengarkan cerita yang disampaikan testee.

- kelemahan : testee merasa cemas karena ceritanya direkam.

(e) Hidden Microphone :

- Tester menggunakan 2 (dua) tenaga sukarela, yaitu : 1 orang untuk mencatat cerita testee, dan 1 orang lagi untuk memperhatikan ekspresi testee.

3. Tahap Pelaksanaan

\section{a. Pelaksanaan $\mathbf{2}$ (dua) hari}

Jika semua kartu disajikan, maka pelaksanaan tes TAT terdiri dari 2 tahap. Prosedur administrasi tes yang asli, seperti yang digunakan Murray (dalam panduan 
administrasi tes oleh Murray), membutuhkan 2 (dua) sesi dengan masing-masing sesi diberi 10 kartu (Anastasi, 2007), yaitu :

Sesi I testee diberi kartu 1 - 10, dan selanjutnya sesi II (minimal sehari sesudahnya) testee diberi kartu 11 20.

Disarankan, testee tidak diberitahu bahwa akan ada penyajian kartu sesi II dengan maksud testee tidak melakukan persiapan diri.

Tahap-tahap pelaksanaannya adalah sebagai berikut :

\section{Tahap I}

(1) Tahap ini dimulai setelah testee duduk, dan persiapan telah dilakukan sebelumnya.

(2) Pelaksanaan tes bisa dimulai dengan memberi instruksi apa yang harus dilakukan testee.

Hal-hal penting yang harus disampaikan sama, yaitu :

a. Testee diminta membuat suatu cerita, bukan sekedar mendeskripsikan gambar yang sedang dihadapi. Cerita yang dibuat berupa peristiwa yang berkembang mengikuti waktu, sehingga ada awal cerita, pertengahan, dan akhir ceritanya.

b. Testee diminta menggunakan imajinasinya saat bercerita, sehingga testee "dipaksa" menginterpretasikan gambar yang sedang dihadapi.

c. Testee diminta menyertakan gambaran perasaan, pikiran, dan lain-lain untuk melukiskan situasi gambar yang sedang dihadapi.

Sedangkan kalimat instruksi bisa disesuaikan dengan kondisi testee. 
a. Untuk testee remaja dan dewasa normal dengan kecerdasan rata-rata, bisa diberi instruksi sebagai berikut (form A) :

" Ini adalah tes imajinasi, yang merupakan bagian dari inteligensi. Saya akan menunjukkan kepada anda sejumlah gambar satu per satu. Katakan awal ceritanya, cerita yang terjadi sekarang, terangkan pikiran dan perasaan para figur, dan bagaimana akhir ceritanya. Katakan apa saja yang ada didalam pikiranmu. Anda mengerti? Waktu anda 5 menit untuk bercerita pada setiap gambar yang saya berikan. Ini kartu pertama"

b. Untuk anak-anak dan dewasa dengan kecerdasan rendah serta penderita psikotik, maka bisa diberi instruksi sebagai berikut (form B) :

"Tes ini adalah tes membuat cerita. Saya mempunyai sejumlah kartu, dan saya akan menunjukkan kepada anda satu per satu, dan buatlah cerita. Katakan apa yang terjadi sebelumnya, dan apa yang terjadi sekarang. Katakan bagaimana pikiran dan perasaan orang-orang tersebut, serta bagaimana akhir ceritanya. Anda dapat membuat cerita tentang apapun. Anda mengerti ? Oke, ini kartu pertama, anda punya waktu 5 menit untuk membuat cerita " 


\section{Catatan :}

- Secara individual, waktu tidak perlu dibatasi, namun biasanya diberikan waktu untuk bercerita 5 menit ( $5^{\prime}$ ) per kartu

(3) Setelah pemberian kartu no. 1, cerita kartu no. 1 perlu dicek : Apakah sudah sesuai dengan instruksi ? terutama, apakah cerita sudah mengandung awal cerita, sedang terjadi, dan akhir cerita. Apakah sudah diceritakan pikiran dan perasaan pada figur dalam gambar ? Dengan kata lain, di sini tester bisa melakukan Intermittent Inquiry.

a) Jika hasil cerita belum sesuai dengan instruksi perlu dikatakan :

"cerita ini sudah baik, tetapi anda belum menceritakan awal cerita / akhir cerita / pikiran / perasaan tokohnya."

(tester menyebutkan bagian yang belum muncul dalam cerita)

b) Jika kriteria tersebut sudah dipenuhi, maka langsung dilanjutkan dengan memberi kartu berikutnya. Instruksi tidak perlu diulang, cukup memberi motivasi dengan mengatakan :

"Cerita anda sudah baik"

(4) Tester bisa memberikan kartu II, dan melakukan hal yang sama seperti pada pemberian kartu I.

\section{Tahap II}

(1) Seperti pada tahap I, tahap ini dimulai setelah testee duduk, dan persiapan telah dilakukan sebelumnya.

(2) Pelaksanaan tes tahap II ini dilaksanakan pada hari kedua (hari selanjutnya). 
Seperti pada tahap I, kalimat instruksi bisa disesuaikan dengan kondisi testee. Instruksi yang diberikan sebelum pelaksanan tes adalah :

Form A :

"Sepuluh cerita anda terdahulu sudah baik, tetapi masih terbatas pada cerita kehidupan sehari-hari. Sekarang coba anda bercerita tanpa memperhatikan kenyataan sehari-hari, dan membiarkan daya khayal bebas. Ini gambar nomer 1 "

Form B :

" Hari ini saya akan menunjukkan beberapa gambar lagi. Gambar-gambar ini lebih mudah karena gambar-gambarnya jauh lebih baik, lebih menarik. Anda telah membuat cerita yang baik sebelumnya. Sekarang, kalau bisa, saya ingin anda membuat cerita yang lebih menarik disbanding sebelumnya, seperti cerita dalam mimpi atau dongeng. Ini kartu pertamanya "

Kartu kosong :

"Coba lihat, apa yang bisa anda lihat pada kartu kosong ini. Bayangkan ada gambar-gambar di kartu ini, dan kemudian jelaskan pada saya"

\section{Catatan :}

$\rightarrow$ Jika testee gagal dengan cara ini, tester bisa mengatakan :

"Tutup mata anda dan coba gambarkan sesuatu di situ" 
Saat testee sudah mendapat bayangan gambaran keseluruhan, maka tester bisa mengatakan :

"Nah, sekarang ceritakan apa yang ada dalam bayanganmu"

Pada dasarnya, pelaksanaan tes sebaiknya dilakukan dalam 2 sesi, yaitu :

(a) sesi 1 : proses proses pengambilan data, yaitu memberi kartu dan meminta testee bercerita tentang gambar yang diberikan padanya.

(b) sesi 2 : menggali lebih dalam / memperjelas data yang dirasa kurang jelas (inquiry)

Ada 2 (dua) bentuk Inquiry :

1. Intermittent Inquiry

$\rightarrow$ dilakukan di sela-sela pemberian kartu atau setelah separuh waktu pelaksanaan tes.

2. Final Inquiry

$\rightarrow$ dilakukan inquiry setelah semua kartu diberikan

\section{Pelaksanaan 1 (satu) hari}

Pelaksanaan tes bisa juga dilakukan hanya 1 (satu) sesi/hari.

Pertimbangan yang digunakan bila melaksanakan tes hanya 1 (satu) hari :

(a) Dalam kasus klinis.

Kebanyakan ahli klinis menggunakan rangkaian singkat dari kartu-kartu yang dipilih secara khusus sesuai dengan dugaan kasus yang ditemukan, dan jarang memberikan lebih dari 10 (sepuluh) kartu pada setiap testee. Tahap pelaksanaannya sama seperti tahap I yang telah dijelaskan di atas (Anastasi, 2007). 
(b) Dalam pelaksanaan tes pada kelompok besar (tes klasikal).

Tester bisa memperpendek penyajian dengan tidak menggunakan seluruh kartu, melainkan menyajikan rangkaian beberapa kartu yang relevan dengan tujuan pengetesan.

\section{B. CAT}

\section{Hal-hal Yang Harus Diperhatikan}

Sama halnya dengan TAT, idealnya, beberapa hal yang harus diperhatikan sebelum menggunakan CAT untuk tujuan apapun, yaitu :

a. Persyaratan umum psikodiagnostik agar hasil tes di sesuai dengan yang kita harapkan meliputi :

1) kesiapan tester

2) rapport yang baik

3) kondisi tempat yang bebas stimulasi

4) atmosfir ruang tes yang nyaman

5) kondisi testee

b. Sebelum memberikan tes CAT, perlu melakukan rapport sekaligus memperoleh identitas testee, seperti :

1) jenis kelamin.

2) usia,

3) tingkat pendidikan,

4) jumlah saudara,

5) nomer urut testee dalam keluarga,

6) hubungan dengan saudara,

7) identitas orang tua,

8) hubungan ayah dan ibu,

9) hubungan dengan teman spesial atau sahabat,

10) taraf kecerdasan (tidak harus tes inteligensi), 
11) kesehatan psikologisnya,

12) permasalahan testee.

\section{Tahap Persiapan}

Persiapan yang harus dilakukan tester sebelum melaksanakan tes CAT meliputi :

a. Persiapan teknis, yaitu : (1) persiapan kartu CAT, dan kelengkapan untuk mencatat jawaban testee ; (2) tempat tes yang nyaman bagi testee anak-anak, dengan penerangan yang memadai agar anak dapat melihat gambar dengan jelas.

b. Melakukan rapport :

(1) Untuk testee anak-anak maka harus ada good rapport dengan anak, karena pada umumnya, menciptakan good rapport akan terasa lebih sulit anak yang lebih muda usianya dan anak "bermasalah";

(2) Tester perlu melakukan konseling awal untuk mendalami permasalahan testee. Tester disarankan untuk mendapatkan sejarah pribadi dan kondisi medis anak sebelum memberikan CAT, agar diketahui apa konteks cerita yang mungkin diberikan testee sehingga bisa ditentukan apakah ceritanya merupakan respon abnormal atau normal.

\section{Tahap Pelaksanaan}

Pelaksanaan tes CAT pada anak-anak hampir sama dengan pelaksanaan tes TAT pada orang dewasa. Hal yang membedakan adalah pelaksanaannya sangat tergantung testeenya, yaitu anak-anak. Oleh karena itu, hal-hal yang harus dilakukan saat pelaksanaanya yaitu : 
a. Pertama, membentuk good rapport.

Bagian ini menjadi bagian yang sangat penting.

Pada umumnya, akan lebih sulit menghadapi anak yang lebih muda atau anak "bermasalah" (CAT diberikan pada anak usia 3-10 tahun). Kondisi ini mengharuskan tester menunjukkan sikap positif kepada testee anak-anak, membentuk good rapport, misal : sebelum mulai tes, tester bisa mengajak testee anak bicara mengenai binatang, atau bermain boneka binatang, dll. Oleh karena itu, disarankan tes CAT diberikan dalam bentuk permainan, bukan sebagai suatu tes, dan dilakukan secara individual.

b. Kedua, melaksanakan tes.

Setelah tester membangun rapport dengan anak, pelaksanaan tes bisa dimulai dengan memberi instruksi apa yang harus dilakukan testee anak-anak.

Pada saat memberi instruksi, bahasa instruksi tidak baku, disesuaikan dengan keadaan testee. Yang utama adalah tester harus bisa menyakinkan testee anak bahwa dia tidak sedang dites. Tester bisa mengatakan pada anak bahwa ia akan melakukan permainan, dimana anak akan diminta untuk bercerita mengenai suatu gambar.

Hal-hal penting yang harus disampaikan sama, yaitu :

(1) Testee diminta membuat suatu cerita, bukan sekedar mendeskripsikan gambar yang sedang dihadapi.

Selama bercerita mengenai gambar, tanyakan pada anak : apa yang dilakukan binatang tersebut, apa yang terjadi sebelumnya, dan sesudahnya (apa yang mungkin terjadi di masa depan).

(2) Testee diminta menggunakan imajinasinya saat bercerita, sehingga testee "dipaksa" menginterpretasikan gambar yang sedang dihadapi. 
Setelah semua cerita cerita terkait, tester boleh bertanya tentang masing-masing cerita untuk elaborasi (memperoleh uraian yang panjang lebar) yang mengarah pada sesuatu yang khusus, seperti : mengapa memberi nama, menyebut tempat tertentu, usia, bahkan menanyakan tentang akhir cerita yang khusus.

Jika perhatian anak sedang tidak memungkinkan mengikuti prosedur ini, bisa kita usahakan di suatu hari sesegera mungkin.

(3) Testee diminta menyertakan gambaran perasaan , pikiran, dan lain-lain untuk melukiskan situasi gambar yang sedang dihadapi.

c. Tester sebisa mungkin memberi banyak dorongan (untuk membesarkan hati) asal tidak mensugesti, dan boleh menginterupsi.

d. Tester juga harus melakukan observasi pada perilaku anak selama dites, seperti: bentuk tingkah laku yang nampak (overt behavior), reaksi terhadap tester, juga reaksi anak terhadap situasi tes maupun pada gambar yang diberikan (misal : respon bercerita lebih lama pada kartu tertentu), dan selanjutnya tester melakukan pencatatan.

e. Jika anak yang meminta tester yang bercerita, maka tester bisa meminta anak untuk bercerita lebih dahulu dengan versi mereka, dan tester bisa memberi janji akan bercerita nanti, atau menunda tes sampai kita bisa mengambil hati anak dengan cara memberi sesuatu, dan kemudian melanjutkan lagi.

f. Jika seorang anak sangat gelisah dan ada indikasi kegelisahannya berhubungan dengan gangguan yang dialami saat itu, maka tester bisa membatasi tes dengan 
memberi beberapa kartu yang bisa menjelaskan gangguan tersebut, misal : anak yang mendapat masalah siblingrivalry, maka harus diberi kartu khusus kartu nomer 1 dan 4 , dst.

g. Sebaiknya gambar tidak diperlihatkan, kecuali kita berhadapan dengan kondisi dimana anak ada kecenderungan untuk bermain dengan semua kartu sekaligus, memilih secara acak untuk diceritakan. Gambar-gambar ini diurut dengan urutan tertentu untuk alasan khusus, dan harus dilakukan dengan urutan yang ditunjuk. 


\section{BAB IV}

\section{ANALISIS TES}

\section{Kemampuan Akhir Yang Direncanakan :}

Setelah mempelajari bab ini, diharapkan mahasiswa mampu memahami analisis cerita TAT dengan metode Bellak, teknik Murray, teknik Henry, maupun teknik Kesan ; serta mampu melaksanakan salah satu analisis cerita yaitu dengan metode Bellak. Mahasiswa juga mampu memahami dan menganalisis cerita CAT.

\section{Pengantar}

Interpretasi pada TAT menekankan pada metode interpretasi yang lebih kualitatif, dan mengakses fitur-fitur "here and now" dari situasi kehidupan seseorang .

\section{A. TAT}

Interpretasi merupakan proses untuk menemukan pola perilaku manusia. Analisis terhadap respon testee pada TAT didesain secara khusus terfokus pada konten simbolik dari respon (cerita) testee.

Hal utama yang harus diingat didalam melakukan interpretasi TAT adalah bahwa gambar-gambar TAT secara psikologis sebaiknya dilihat sebagai rangkaian situasi sosial dan hubungan interpersonal. Selain merespon manusia "riil" dalam situasi yang "riil", ternyata individu juga memberi respon pada orang lain atau obyek yang ada dalam gambar, yang dibayangkan seperti dalam situasi tertentu, dan respon yang ditunjukkan dianggap mewakili "inner feeling"-nya. 
Ada beberapa metode yang bisa digunakan untuk menginterpretasi hasil pengukuran kepribadian dengan menggunakan TAT, yaitu : (1) metode Bellak ; (2) teknik Murray ; (3) teknik Henry ; (4) teknik kesan, dan masih banyak lagi. Di bawah ini, penjelasan 4 metode atau teknik analisis cerita dalam TAT.

\section{Metode Bellak}

Metode penyekoran dan interpretasi dari Bellak dianggap paling sederhana dan paling sering digunakan dan dimutakhirkan dibanding sistem lainnya (Marnat, 2010). Ada 2 (dua) macam interpretasi dengan menggunakan metode Bellak, yaitu dengan menggunakan long-form dan shortform (Bellak, 1975).

Interpretasi dengan menggunakan metode Bellak mengharuskan pemberian skor terhadap 10 variabel, dengan Long-Form maupun Short-Form, sebagai berikut :

\section{a. SKORING}

Bellak mengemukakan ada 10 (sepuluh) variabel yang perlu diperhatikan dalam usaha untuk menginterpretasi hasil pengukuran kepribadian dengan TAT. Bellak membuat desain sistem untuk skoring dan interpretasi. Panduan dalam melakukan interpretasi, yang dikenal dengan "Bellak T.A.T. Blank and Analysis Sheet". Sistem ini mengandung sepuluh variabel yang disarankan Bellak. Kesepuluh variabel itu adalah :

1. Tema Utama

2. Tokoh Utama

3. Kebutuhan-kebutuhan dan Dorongan-dorongan Utama dari Hero

4. Konsep Hero tentang lingkungan 
5. Sosok yang ada di lingkungan Hero dilihat sebagai

6. Konflik-konflik yang signifikan

7. Hakekat kecemasan

8. Defens-defens Utama untuk melawan konflik dan ketekutan

9. Ketepatan Super-ego sebagaimana ditampakkan dalam bentuk "hukuman" terhadap "kejahatan"

10. Integrasi Ego

Menurut Bellak, sistem yang dibuatnya merupakan sistem yang cukup sederhana dan paling mudah untuk dikuasai sebagai pegangan dan sebagai "frame of reference".

Selanjutnya akan dibahas masing-masing variabel tersebut sehingga bisa digunakan untuk pegangan didalam melakukan analisis untuk setiap cerita yang disampaikan testee selama tes diberikan.

\section{Tema Utama}

Tema utama dimaksudkan untuk memahami inti cerita atau jiwa cerita (perlu diingat bahwa 1 cerita TAT mungkin sekali memiliki lebih dari 1 tema pokok). Setiap cerita mempunyai suatu dinamika, dan dinamika itu yang merupakan plot cerita.

Tema merupakan elemen terpenting dalam cerita. Pada tema yang simpel, akan selalu mengandung need, press, dan outcome (akhir ceritanya).

Untuk memudahkan memahami dan menemukan intisari cerita, Bellak mengemukakan 5 (lima) tingkat tema, yaitu :

1. Tema deskriptif_:

Tema deskriptif pada dasarnya dimaksudkan untuk meringkas cerita. Cara meringkas cerita, yaitu dengan 
membuang hal-hal yang kurang mendukung intisari, maupun kata-kata yang tidak relevan, sehingga alur ceritanya menjadi jelas.

Pedoman penyusunan tema deskriptif :

a. Sebisa mungkin menggunakan kata-kata testee seperti dalam cerita.

b. Alur cerita dibuat sesuai dengan "kacamata" hero

c. Alur cerita dibuat secara kronologis, dari awal cerita (apa yang terjadi sebelumnya), kemudian apa yang terjadi sekarang (seperti dalam gambar), dan akhir cerita (apa yang akhirnya terjadi).

d. Informasi-informasi yang dianggap relevan untuk tema deskriptif yaitu : perilaku, kebutuhan, press, konflik, defens mekanisme yang digunakan, struktur kepribadian yang berperan (id, ego, atau super-ego), atau sosok lain dalam cerita.

2. Tema interpretif :

Tema interpretif dimaksudkan untuk memberi makna dari dinamika cerita (dengan cara melihat alur ringkasan cerita yang tercantum di tema deksriptif) dalam bentuk hipotesis pikiran testee. Hipotesis ini menggambarkan pandangan dari testee mengenai apa yang terjadi jika kutub need (kebutuhan) bertemu dengan kutub press.

Untuk memudahkan generalisasi, susunan kalimatnya disarankan menggunakan rumusan di bawah :

$\rightarrow$ jika seseorang maka

3. Tema diagnostik :

Tema diagnostik dimaksudkan untuk memberi gambaran tentang :

- diri atau karakteristik tokoh utamanya (hero),

- karakteristik tokoh lain (menurut pandangan subyek), 
- need (kebutuhan-kebutuhan) hero,

- press,

- konflik-konflik,

- kecemasan,

- bentuk-bentuk defens mekanisme yang digunakan hero untuk mengatasi konflik/kecemasannya,

- perubahan emosi yang terjadi, dan

- akhir cerita.

4. Tema simbolik:

Pada tahap ini, kita mencari interpretasi simbol berdasar hipotesis psikoanalisa, misal : bermain biola sebagai simbol seksual, khususnya masturbasi, dsb.

5. Tema elaboratif:

Pada tahap ini, kita melakukan asosiasi bebas atas elaborasi testee dalam ceritanya, misal : "insinyur" (pekerjaan tokoh utama), atau "India Timur" (suatu tempat khusus yang disebutkan oleh tokoh utama) dihubungkan (diasosiasikan) dengan nama atau tempat tinggal khusus yang memiliki makna khusus bagi testee

\section{Tokoh Utama}

Tokoh utama (hero) adalah tokoh yang dijadikan acuan identifikasi oleh si pembuat cerita. Biasanya terwakili pada orang (tokoh) yang paling banyak diceritakan, perasaan-perasaan dan pikiran-pikiran subyektifnya paling banyak diungkapkan, atau yang disebut sejak awal sampai akhir cerita.

Adakalanya, subyek/testee pria mengidentifikasikan dirinya pada figur (tokoh) wanita dalam cerita, misal pada: 
a. kartu 2 : testee pria muda mengidentifikasikan dirinya pada tokoh wanita muda dalam cerita, atau

b. kartu 3 BM : beberapa pria muda mengidentifikasi dirinya pada tokoh utamanya sebagai wanita.

Jika hal ini sering terjadi bisa menjadi indikasi adanya kecenderungan homoseksual laten.

Pekerjaan, minat, sifat, kemampuan, dan adequacy, juga body image dari tokoh utama seringkali melukiskan kualitas yang diinginkan testee. Berikut penjelasannya :

a. Adequacy hero

- Kemampuan tokoh utama didalam menjalankan kegiatan atau mengatasi kesulitan di bawah tekanan kesulitan dari luar maupun dari dalam diri, dengan cara yang dapat diterima atau bernilai positif secara, sosial, moral, emosional atau intelektual.

- Adequacy hero mencerminkan ego-strength testee.

b. Body image/Self image

- Kesan testee tentang tubuhnya.

- Jika dalam satu cerita terdapat banyak tokoh, dan ragu menentukan mana tokoh utamanya, maka tokoh utamanya sebaiknya dipilih sosok yang paling mendekati sama dalam hal : umur, jenis kelamin, maupun karakteristik lainnya.

\section{Kebutuhan-kebutuhan dan}

\section{Dorongan-dorongan Utama Hero}

\section{a. Behavioral need}

- Kebutuhan yang mudah manifest dalam perilaku, seperti tampak pada perilaku figur/tokoh cerita. 
- Behavioral need ini bisa berhubungan langsung dengan perilaku testee, tetapi dapat juga tidak ada kaitannya sama sekali, karena hanya fantasi testee. Untuk itu perlu data biografi testee yang maksimal (dalam hal ini, data TAT dianggap sebagai data komplementer bagi data biografi tersebut).

Harus diingat bahwa seringkali fantasi jauh lebih tinggi dan perilaku riil-nya justru sangat rendah. Kondisi seperti ini biasanya terjadi karena kebutuhan-kebutuhan dilarang dimanifestasikan oleh budaya.

\section{- Dinamika inferensi :}

Misal : jika subyek nampak seringkali supportif dengan figur lain, patut dicurigai ada kemungkinan testee mengidentifikasikan dirinya dengan tokoh kedua atau ketiga. Hal ini bisa berarti : sifat figur/tokoh nurturance (suka berempati), tetapi sifat testee sebenarnya adalah succorance (suka membantu yang kesusahan).

\section{b. Figur, obyek, atau lingkungan yang dimasukkan dalam cerita}

Hal-hal yang dimasukkan dalam cerita mempunyai arti bahwa subyek mempunyai kebutuhan yang tidak disadari sesuai kegunaannya secara simbolik.

Misal : jika subyek memasukkan senjata (dalam cerita), walaupun tidak digunakan; dan memasukkan makanan (dalam cerita), walaupun tidak dimakan, maka secara tentatif dapat diinterpretasikan sebagai kebutuhan agresi dan oral. 
c. Figur, obyek, atau lingkungan yang ada dalam gambar tapi diabaikan dalam cerita.

- Pengabaian hal-hal yang ada dalam gambar merupakan indikasi adanya pengingkaran (denial) atau represi, misal : jika subyek mengabaikan senjata pada gambar $3 \mathrm{BM}, 8 \mathrm{BM}$, dan wanita yang mencekik pada gambar $18 \mathrm{GF}$, salah satu kemungkinan kesimpulannya adalah represi agresi.

- Pengabaian gambar setengah busana pada gambar 4, dan peniadaan referensi seksual pada gambar 13 MF, kemungkinan kesimpulannya adalah represi seksual.

\section{Konsep Hero tentang lingkungan}

Lingkungan adalah keadaan yang ada di luar diri, yang mewarnai inti cerita, berupa : manusia, atau lingkungan fisik di luar tokoh utama (hero).

Konsep tentang lingkungan adalah percampuran antara persepsi diri yang tidak disadari dengan distorsi appersepsi stimuli karena adanya jejak-jejak ingatan di masa lalu. Konsepsi ini tergambar saat tokoh dalam cerita menyebutkan beberapa sifat lingkungan dimana tokoh berada, antara lain :

\begin{tabular}{|l|l|}
\hline \multicolumn{2}{|c|}{ konsep-konsep tentang lingkungan : } \\
\hline - penuh pertolongan & - terkontrol \\
\hline - kejam & - membosankan \\
\hline - agresif & - kacau \\
\hline - eksploitatif & - kotor \\
\hline - ramah & - membingungkan \\
\hline - berbahaya & - penuntut \\
\hline - rakus & - menekan, dsb. \\
\hline
\end{tabular}




\section{Sosok yang ada di lingkungan Hero dilihat sebagai}

Bellak memandang gambar-gambar dalam kartu TAT sebagai serangkaian situasi sosial, dimana terjadi interaksi interpersonal. Oleh karena itu, di masingmasing kartu perlu dilihat bagaimana hero bersikap (melihat dan bereaksi) terhadap orang-orang atau obyek yang ada di sekitarnya.

TAT merupakan alat utama untuk mengungkapkan dinamika \& appersepsi distorsi tentang hubungan sosial.

Bagaimana hero memandang figur di lingkungan dibedakan menurut kelompok umur, yaitu :

a. Figur orang tua / lebih tua / superior

b. Figur sebaya

c. Figur lebih muda / inferior

Figur-figur di atas digambarkan secara umum dengan figur, yang antara lainbersifat :

\begin{tabular}{|l|l|}
\hline \multicolumn{2}{|c|}{ Hero memandang figur memiliki sifat : } \\
\hline - Memberi nasehat/ perintah/ hukuman/ pembatasan \\
\hline - Supportif & - Kompetitif \\
\hline - Lemah & - Agresif \\
\hline - Kurang mampu & - kotor \\
\hline - Pasif & - menolak, dsb. \\
\hline
\end{tabular}

Disini bisa dipelajari bagaimana sikap hero terhadap ketiga figur tersebut. Reaksi hero mencerminkan bentuk pertahanan-pertahanannya (defens mekanisme).

Pertahanan tersebut merupakan upaya hero untuk menanggapi atau mengkompromikan kebutuhankebutuhannya selama berhubungan dengan orang lain.

Bagaimana reaksi yang dilakukan hero terhadap figur di lingkungannya, antara lain : 


\begin{tabular}{|l|l|}
\hline \multicolumn{2}{|c|}{ Reaksi Hero terhadap figur } \\
\hline - Lari ke alam fantasi & - Ada kemarahan \\
\hline - Ambivalen / mendua & - Penarikan diri \\
\hline - Ada perasaan bersalah & - Upaya mencapai otonomi \\
\hline - Depresi & - Pemberontakan \\
\hline - Agresi & - Perlawanan, dsb. \\
\hline
\end{tabular}

\section{Konflik-konflik yang signifikan}

Tes TAT dianggap bisa membantu mengetahui konflik testee, dan defens mekanisme yang digunakan testee untuk mengatasi kecemasan yang ditimbulkan oleh konflik yang dialami testee. Konflik dapat terjadi antara :

a. Dorongan dengan dorongan, misal :

- doronganberprestasi vs dorongan kesenangan

- dorongan otonomi vs dorongsn ketaatan

- dorongan passivity vs dorongan counteraction (dorongan untuk malas setelah melakukan sedikit usaha vs dorngan untuk mencoba dan mencoba lagi)

b. Struktur kepribadian dengan agresi, misal :

- super ego vs agresi

c. Need dengan press, misal:

- understanding vs restraint (kebutuhan untuk mendapat pendidikan vs orang tua melarang)

\section{Hakekat kecemasan}

Kecemasan adalah kekhawatiran yang tidak ada dasarnya atau alasan nyata. Ada beberapa macam kecemasan yang mungkin dialami individu :

a. Kecemasan akan adanya bahaya fisik atau hukuman. 
b. Kecemasan bahwa tindakannya tidak disetujui.

c. Kecemasan akan kehilangan cinta.

d. Kecemasan akan ditinggal, dibiarkan (baik secara fisik maupun emosional).

e. Kecemasan akan penyakit.

f. Kecemasan akan kekurangan / kemiskinan.

g. Kecemacan akan dikalahkan (tidak berdaya).

h. Kecemasan akan dimusnahkan

\section{Defens-defens Utama untuk melawan} konflik dan ketakutan

Ego Defens digunakan untuk mengatasi dorongan. Analisis terhadap ego defens ini akan bisa mengetahui dorongan yang dimiliki testee.

Pada kenyataannya, dalam TAT, informasi tentang ego defens sangat jelas jika dibandingkan dengan informasi tentang dorongan itu sendiri, dan defens itu berkaitan dengan perilaku overt.

Contohnya :

- Beberapa subyek memilih defens mekanisme obsesif dalam menghadapi gambar-gambar yang tidak menyenangkan, sehingga mereka membuat 4 atau 5 tema untuk setiap cerita yang dibuat cenderung pendek-pendek dan bersifat deskriptif (hanya menyebut satu persatu gambar yang ada, tidak membuat cerita). Hal ini, secara manifestasi berbeda, tetapi secara dinamik identik.

- Beberapa tema berurutan pada satu gambar ke gambar lain dan pada gambar yang sama. Hal ini menunjukkan adanya usaha subyek untuk menolak konflik yang tidak menyenangkan. Pada tema, 
kemungkinan akan memunculkan dorongan yang dilarang muncul selama ini.

\section{Adekuasi (Ketepatan) Super-ego sebagaimana ditampakkan dalam bentuk "hukuman terhadap kejahatan"}

Hukuman terhadap kejahatan adalah sejauh mana super-ego memberi hukuman pada ego yang telah melakukan tindakan (yang melanggar aturan super-ego) dalam rangka memuaskan id.

Hal-hal yang perlu diperhatikan adalah : apakah perbuatan-perbuatan dalam cerita dianggap sebagai kejahatan atau tidak. Ada perbuatan yang sebenarnya merupakan kejahatan, tetapi oleh subyek dianggap permainan, misal : cerita tentang film-film cowboy.

Dalam menilai hukuman, harus dilihat dari sudut pandang moril subyek. Berat ringannya hukuman memberikan insight tentang kualitas super-ego.

a. Hukuman adil : menunjukkan subyek memiliki jalan pikiran yang seimbang.

b. Hukuman lunak atau jarang memberi hukuman : menunjukkan indikasi psikopat.

$\rightarrow$ Subyek yang psikopat, misal, biasanya "tidak memberikan hukuman" pada perbuatan "membunuh", mungkin hanya "memberi sugesti bahwa hal itu merupakan pelajaran di kemudian hari".

c. Hukuman yang keras : terlihat pada subyek yang neurotik.

$\rightarrow$ Orang Neurotik, misal, biasanya membuat cerita hero dibunuh, dihukum, dianiaya, mati karena 
sakit, baik sengaja maupun tidak sengaja disebabkan oleh pelanggaran atau ekspresi agresi walaupun minimal.

d. Hukuman yang sangat berat atau sangat ringan : menunjukkan super-ego yang tidak terintegrasi dan juga neurotik.

\section{Integrasi Ego}

Integrasi ego menunjukkan sejauh mana subyek mampu berfungsi secara baik. Oleh karena itu, interpretasi integrasi ego akan memberikan informasi tentang :

a. Kemampuan subyek mengkompromikan antara dorongan-dorongan yang dimiliki dengan tuntutantuntutan realitas di satu pihak, dan bagaimana super-ego memimpin struktur kepribadian lain (id, ego) di lain pihak.

b. Ketepatan hero dalam menghadapi masalah.

Hal ini bisa diketahui dengan cara mengkonfrontasikan gambar dengan bagaimana appersepsi subyek tentang stimulus gambar tersebut.

Karakteristik formal yang perlu diperhatikan berkaitan dengan kekuatan ego (ego-strength), yang meliputi :

a. Apakah subyek mampu membuat cerita dengan memperhatikan aspek adaptif dari stimulus secara layak, ataukah mengabaikan stimulus, atau membuat cerita yang tidak ada hubungannya dengan gambar karena subyek kurang memahami realitas atau sangat terikat dengan masalahnya sendiri dan membiarkan masalahnya di luar. 
b. Bagaimana cara subyek mengatasi kecemasan ? apakah dengan cara membuat cerita secara stereotip, inteligen, kreatif, original ?

c. Plot cerita yang dihasilkan. Bagaimana cara pemecahan/solusi konfliknya ? apakah tepat, komplit, realistik, terstruktur, aneh/bizarre?

d. Harus diperhatikuan juga, seberapa jauh jarak subyek dengan cerita yang dibuat?

- Jika setting cerita terjadi di tempat yang jauh, terjadi sekian tahun yang lalu, hero hanya sebagai penonton, atau cerita berasal dari film, situasi emosional dilukiskan secara sarkastik, maka ini indikasi usaha subyek menggunakan defens mekanisme isolasi.

- Jika subyek melibatkan diri dalam cerita secara personal, misal :

$\rightarrow$ subyek berkata " ... hal ini seperti yang terjadi pada diri saya", maka ini indikasi ada kecenderungan narsistik.

\section{b. FORM INTERPRETASI T.A.T}

Dalam usaha menginterpretasi hasil tes, Bellak telah mendisain sistem untuk skoring dan interpretasi dan dikenal dengan "Bellak T.A.T. Blank and Analysis Sheet", yang mengandung 10 variabel, dan telah dijelaskan di atas.

Ada 2 (dua) macam form yang dibuat Bellak untuk interpretasi hasil tes dengan TAT, yaitu : (1) long-form , (2) short-form. Kedua bentuk form akan dijelaskan seperti di bawah : 


\section{(1) LONG-FORM}

Blangko TAT dengan model long-form terdiri dari 1 (satu) folder dengan 6 (enam) halaman ditambah recording dan analysis sheetyang terpisah, dan 1 (satu) folder rangkapnya.

Di cover laporan diisi catatan tentang :

- data pribadi klien

- hasil analisis yang sudah lengkap (ditulis di kolom : Laporan Akhir).

Urutan susunan model long-form adalah sebagai berikut :

\begin{tabular}{|c|l|}
\hline halaman & \multicolumn{1}{|c|}{ isi } \\
\hline 1 & Identitas klien, dan laporan akhir \\
\hline 2 & $\begin{array}{l}\text { narasi cerita 1, dilanjutkan tabel tema } \\
\text { (deskriptif, interpretif, diagnostik) dan } \\
\text { selanjutnya catatan klinis ; narasi cerita2 } \\
\text { ditulis di balik lembar analisis; narasi cerita } \\
3 \text { di tulis di balik lembar analisis lainnya; } \\
\text { demikian seterusnya sampai seluruh narasi } \\
\text { dan analisis dari seluruh kartu TAT. }\end{array}$ \\
\hline 3 & Lembar analisis cerita terakhir \\
\hline 4 & ringkasan masing-masing cerita \\
\hline
\end{tabular}

Contoh susunan Long-Form bisa dilihat di halaman lampiran.

Catatan :

Bagi pemula, bisa menggunakan model Long-Form dianggap model yang cukup sederhana dan paling mudah untuk dikuasai. 


\section{(2) SHORT-FORM}

Short-form dari BELLAK pertama kali dikenalkan terutama untuk tujuan klinis. Variabel yang digunakan sama dengan variabel di long-form, dan terdiri dari form 3 (tiga) halaman yang menyambung. Setiap variabel bisa dicatat pada kotak-kotak yang sesuai untuk kesepuluh cerita, dan kesimpulan diletakkan paling kanan dalam kolom yang sama.

Bagi pemula yang belajar TAT diharapkan menggunakan long-form, karena dengan menguasai long-form akan jauh lebih mudah untuk menguasai short-form dibandingkan bila mempelajari sebaliknya.

Short-form digunakan dengan menggunakan pendekatan deduktif, artinya halaman awal (halaman 1) berisi kesimpulan dan rekomendasi yag hendak diberikan kepada klien; sedangkan halaman tengah $(2,3,4)$ berisi analisis lengkap yang terinci. Halaman 5 diisi dengan rating terhadap fungsi ego yang didasarkan pada : (a) anamnese; (b) hasil pemeriksaan TAT; (c) observasi terhadap perilaku testee.

Urutan susunan model short-form adalah :

\begin{tabular}{|c|c|c|}
\hline hal & isi & keterangan \\
\hline 1 & $\begin{array}{l}\text { Pemberian } \\
\text { kesimpulan } \\
\text { dan reko- } \\
\text { mendasi }\end{array}$ & $\begin{array}{l}\text { - Pada dasarnya halaman ini berisi } \\
\text { intisari atau abstraksi atas semua } \\
\text { temuan yang diperoleh melalui } \\
\text { analisis yang cermat dan rumit. } \\
\text { - Karena berisi rumusan abstrak, } \\
\text { maka biasanya sulit untuk dipahami } \\
\text { oleh orang awam.Yang langsung } \\
\text { dapat memahami secara akurat } \\
\text { adalah rekan sejawat. } \\
\text { - Bellak menyarankan, }\end{array}$ \\
\hline
\end{tabular}




\begin{tabular}{|c|c|c|}
\hline & & $\begin{aligned} & \rightarrow \text { alinea pertama berisi rumusan } \\
& \text { abstrak yang merangkum semua } \\
& \text { hasil pemeriksaan } \\
& \rightarrow \text { alinea kedua berisi saran-saran } \\
& \text { (rekomendasi) kongkrit, sehingga } \\
& \text { orang awam sekalipun dapat } \\
& \text { membacanya. }\end{aligned}$ \\
\hline 2 & $\begin{array}{l}\text { Pedoman } \\
\text { pengisian } \\
\text { halaman } \\
2,3,4\end{array}$ & $\begin{array}{l}\text { - Halaman ini juga digunakan juga } \\
\text { untuk mencantumkan hasil gam- } \\
\text { baran umum yang berulang dari } 1 \\
\text { cerita ke cerita lain. } \\
\text { - Isinya adalah : } \\
\text { 1. Tema Utama } \\
\text { 2 Tokoh Utama } \\
\text { 3 Kebutuhan - kebutuhan dan } \\
\text { Dorongan - dorongan Utama } \\
\text { dari Hero } \\
\text { 4. Konsep Hero tentang lingkungan } \\
\text { 5. Sosok yang ada di lingkungan } \\
\text { Hero dilihat sebagai ........ } \\
\text { 6. Konflik-konflik yang signifikan } \\
\text { 7. Hakekat kecemasan } \\
\text { 8. Defens-defens Utama untuk } \\
\text { melawan konflik dan ke-takutan } \\
\text { 9. Ketepatan Super-ego sebagai- } \\
\text { mana ditampakkan dalam } \\
\text { bentuk "hukuman" terhadap } \\
\text { "kejahatan" } \\
\text { 10. Integrasi Ego }\end{array}$ \\
\hline 3 & \multicolumn{2}{|c|}{ Analisis per kartu menurut pedoman pada halaman 2} \\
\hline 4 & \multicolumn{2}{|c|}{ Pembuatan ringkasan } \\
\hline 5 & \multicolumn{2}{|c|}{ Rating yang diberikan terhasap fungsi ego } \\
\hline
\end{tabular}

Catatan : Contoh susunan short-form bisa dilihat di halaman lampiran 


\section{c. KESIMPULAN dan LAPORAN AKHIR}

(1) Kesimpulan

Setelah semua cerita dianalisis, semua data utama ditulis di halaman 4.

Ketika halaman kesimpulan kita telaah, dan setelah analisis seluruh cerita sudah lengkap, maka pola pengulangan pada respon-respon asli dari subyek akan bisa lita lihat secara jelas.

\section{(2) Laporan Akhir}

Bagaimana bentuk laporan, ada beberapa :

a. Secara umum laporan akhir dapat ditulis leng-kap di halaman kesimpulan.

Hal ini menunjukkan bahwa form laporan akhir akan mengikuti urutan 10 kategori seperti di analysis sheet :

(1) Tema utama, variabel ke - 2 dan ke - 3 : menggambarkan struktur ketidaksadaran \& kebutuhan-kebutuhan subyek.

(2) Variabel ke-4 \& ke-5 : menunjukkan pada kita konsep subyek tentang dunia dan orang-orang penting yang ada di sekitarnya.

(3) Variabel ke-6, ke-7,ke-8, ke-9 \& ke-10 : bisa digunakan sebagai kepala (heading) dari pernyataan kita yang berkaitan dengan dimensidimensi kepribadian masing-masing.

b. Bagaimana bentuk laporan akhir akan tergantung pada tujuan pembuatan laporan.

Apabila kita menjadi bagian dari tim penanganan klien (dengan psikiater dan pekerja sosial yang tidak 
memiliki banyak waktu atau pengalaman untuk membaca cerita klien), kita bisa menyusun laporan dengan mengikuti pedoman sebagai berikut :

(1) Setengah laporan awal berisi :

pernyataan abstraksi umum tentang subyek.

(2) Bagian kedua dari laporan harus berisi :

dokumentasi khusus dan konkrit yang diperoleh dari cerita atau referensi khusus tentang cerita yang mendasari pernyataan abstraksi sebelumnya.

c. Jika harus membuat diagnosa, rumusan yang disarankan adalah :

$\rightarrow$ " Data yang diperoleh dari TAT mengarah pada diagnosa ..............".

Pernyataan ini menunjukkan bahwa TAT bukan alat diagnosa utama, dan juga menunjukkan bahwa tidak ada diagnosa yang dibuat berdasar pada alat diagnosa tunggal. Sebaiknya hasil tes dilengkapi dengan informasi tambahan yang diperoleh dari hasil interviu klinis.

\section{Teknik Murray}

Teknik interpretasi TAT yang dilakukan Murray merupakan teknik Analisis Isi (Content Analysis). Menurut Murray, analisis isi pada TAT merupakan faktor utama, sedangkan analisis lainnya hanya merupakan tambahan dari analisis isi. Teknik ini mempunyai keunggulan tersendiri, terutama bila dipakai untuk penelitian yang mendalam, serta tidak ada tuntutan untuk selesai dengan segera, 
karena membutuhkan waktu yang lebih lama didalam menginterpretasi hasil tes bila menggunakan TAT

Dengan menggunakan analisis ini, Murray menyarankan pemeriksa melakukan analisis di setiap kejadian dalam cerita ke dalam 5 (lima) variabel :

a. Kekuatan-kekuatan yang berasal dari tokoh cerita (hero)

b. Kekuatan-kekuatan yang berasal dari lingkungan (press)

c. Interes dan sentiment

d. Tema

e. Outcome

Selanjutnya, di bawah akan dibahas masing-masing variabel tersebut sehingga bisa digunakan untuk pegangan didalam melakukan analisis isi terhadap setiap cerita testee :

\section{a. Kekuatan-Kekuatan Yang Berasal Dari Tokoh Cerita (Hero)}

Langkah pertama yang harus dilakukan pemeriksa setiap melakukan analisis dengan teknik ini adalah :

(1) Menemukan tokoh (Hero), tempat dimana testee mengidentifikasi dirinya. Hero biasanya terwakili pada :

a. Orang dalam cerita, yang paling menarik minat si pengarang, sehingga dalam cerita paling banyak digambarkan perasaan maupun motif-motifnya.

b. Orang dalam cerita, yang paling mirip keadaannya dengan testee (baik dalam hal jenis kelamin, usia, status atau perannya).

c. Orang dalam cerita, yang diceritakan dari awal hingga akhir.

(2) Menganalisis karakter yang dimiliki Hero, antara lain :

a. Umur

b. Jenis kelamin 
c. Kecakapan-kecakapan, seperti : superioritas atau inferioritas (mampu atau tidak mampu).

d. Minat-minatnya

e. Karakter-karakter lain, seperti: apakah kriminal, abnormal, cenderung bertengkar, bagaimana kepemimpinannya, dsb.

f. Body-image, bagaimana pandangan Hero tentang dirinya sendiri

g. Adekuasi Hero

$\rightarrow$ Hero disebut adekuat, jika Hero cakap dalam menghadapi keadaan yang sesuai dengan pandangan masyarakat dimana Hero hidup.

$\rightarrow$ Adekuasi Hero menunjukkan kekuatan ego testee.

- Adekuasi yang berlebihan menunjukkan adanya tendensi kompensatoris.

- Adekuasi tinggi, misal : saat diberi tugas, Hero dapat menyelesaikan tugas dengan cepat dan tidak mengeluh

- Tidak adekuat, misal : saat diberi tugas, Hero banyak mengeluh dan melarikan diri dari tugas tsb.

(3) Mengamati motif dan perasaan Hero

- Disini, pemeriksa mengamati secara terinci : perasaan, pikiran, dan tindakan-tindakan Hero, juga memperhatikan apakah ada tanda-tanda yang berhubungan dengan kepribadian tertentu atau dengan kelainan jiwa, juga hal-hal khusus atau unik tetapi dengan intensitas sangat tinggi atau rendah.

- Murray membuat klasifikasi need (kebutuhan) sebanyak 28 need berdasar arah, tujuan, serta 
keaktifannya. Daftar kebutuhan seperti yang ada pada EPPS (Edward Personal Preference Schedule)

- Menurut Murray :

$\rightarrow$ suatu kebutuhan akan tampak dalam bentuk impuls, keinginan, maksud, atau suatu tingkah laku nyata.

$\rightarrow$ kebutuhan (need) dapat berpadu, sehingga suatu tindakan dapat memuaskan sekaligus 2 (dua) need.

$\rightarrow$ kebutuhan (need) dapat berfungsi sebagai instrumen (subsidiary) dan dapat dipakai sebagai alat bantu memuaskan kebutuhan yang dominan.

- Secara garis besar, beberapa need bisa dikelompokkan menjadi 2 :

a. Need yang bisa diberi skor kekuatannya.

Skor kekuatan need diberikan berdasar pada : (1) intensitas, (2) durasi (lama berlangsungnya), (3) frekuensi, (4) seberapa penting need tersebut dalam cerita.

Skornya berkisar 1-5, antara lain :

\begin{tabular}{|c|l|}
\hline skor & \multicolumn{1}{|c|}{ keterangan } \\
\hline 1 & $\begin{array}{l}\text { intensitasnya kecil (misal : sedikit memiliki } \\
\text { sifat marah) }\end{array}$ \\
\hline $2,3,4$ & $\begin{array}{l}\text { ekspresinya menunjukkan intensitas yang } \\
\text { agak kuat }\end{array}$ \\
\hline 5 & $\begin{array}{l}\text { intensitasnya kuat (misal : kemarahan yang } \\
\text { kasar/mengamuk), atau yang intensitasnya } \\
\text { lebih ringan tetapi terjadi terus menerus } \\
\text { atau berulang (misal : selalu bertengkar) }\end{array}$ \\
\hline 0 & $\begin{array}{l}\text { kekuatan paling rendah, sehingga variabel } \\
\text { ini tidak tampak }\end{array}$ \\
\hline
\end{tabular}


Need yang diberi skor, yaitu :

need (1) Abasement, (2) Achievement, (3) Aggression (dibedakan menjadi: a. Emosional dan Verbal, b. Physical, Social, c. Physical, Asocial, d. Destruction), (4) Dominance, (5) Intraggression, (6) Nurturance, (7) Passivity, (8) Sex, (9) Succorance

b. Need yang tidak diberi skor :

need (1) Acquisition (terdiri dari : Sosial dan Asosial), (2) Affiliation (terdiri dari : Asosiatif dan Emosional), (3) Autonomy (terdiri dari : Kebebasan, Bertahan, dan Asosial), (4) Blamavoidance, (5) Cognizance, (6) Deference (terdiri dari : Patuh dan Hormat), (7) Excitance, (8) Exposition, (9) Harmavoidance, (10) Change, travel, Adventure, (11) Construction, (12) Counteraction, (13) Nutriance, (14) Playmirt, (13) Retention, (15) Understanding, (16) Rejection, (17) Sentience (terdiri dari : Epiqurean dan Aesthetic) (catatan : keterangan masing-masing need bisa dilihat di halaman lampiran)

(4) Menganalisis inner-state dan emosi Hero Selain menganalisis need dari Hero, juga harus menganalisis inner state (keadaan batin) dan emosi Hero.

Adapun inner state dan emosi Hero yang dianggap penting :

a. Kecemasan

Kecemasan adalah kekhawatiran yang tidak mempunyai dasar atau alasan yang nyata, misal :

- kecemasan karena mendapat luka fisik dan hukuman.

- kecemasan tindakan, kehidupan, dan perbuatannya tidak disetujui. 
- kecemasan akan kehilangan cinta dari seseorang.

- kecemasan akan ditinggal atau dibiarkan (secara fisik atau emosional).

- kecemasan mendapat penyakit atau luka-luka.

- kecemasan mengalami kemiskinan, kekurangan, kurang aman, tidak dapat meneruskan hidup secara layak.

- kecemasan dikalahkan dan tidak berdaya lagi.

- kecemasan akan dimusnahkan.

b. Konflik

Konflik adalah keadaan yang tidak menentu, tidak dapat memutuskan, terkatung-katung. Konflik yang dialami dapat melalui bermacam tingkat :

1. konflik yang timbul pada suatu saat, misal :

- pertentangan antara dorongan, keinginan, tujuan, atau impuls-impuls .

- konflik moaral antara dorongan dengan norma.

2. konflik berkembang menjadi sesuatu yang menghambat, yang dapat melumpuhkan Hero, atau Hero tidak dapat berbuat apa-apa.

3. konflik mencapai puncak, misal :

- Dalam keadaaan ragu-ragu yang memuncak, atau kebingungan, sehingga Hero tidak dapat berbuat apa-apa.

c. Dejection

Dejection adalah feeling of inner state, dimana Hero merasa tidak berharga, tidak bernilai, tidak bermakna, misal : perasaan gagal (termasuk : 
perasaan kecewa, depresi, sedih, tidak bahagia, melankolis, putus asa ).

d. Perubahan emosi

Perubahan emosi adalah terjadinya perubahan perasaan seseorang karena perkembangan fase-fase sesuai dengan periodisasinya, misal : mengalami perubahan perasaan terhadap seseorang.

e. Distrust / jealousy

Distrust dapat dibagi dalam tingkatan :

1. ketidakpercayaan yang muncul sesaat karena ada nya pandangan-pandangan atau dugaan-dugaan atau perbuatan-perbuatan tertentu.

2. ketidakpercayaan menjadi pola berpikir Hero karena pengalaman sebelumnya. Hero menjadi tidak percaya lagi pada orang lain, bersifat hatihati pada orang lain.

3. Ketidakpercayaan yang terintegrasi kedalam kepribadian. Hero tidak dapat lagi hidup dengan lingkungannya, Hero putus hubungan dengan lingkungannya

\section{b. Kekuatan-kekuatan yang berasal dari lingkungan (press)}

Guna menganalisis bagaimana hero mempersepsi kekuatan-kekuatan lingkungannya, interpreter harus : 
1. mengamati detil-detil dari sifat umum dari situasi-situasi, khususnya situasi manusia yang bertentangan dengan hero,

2. menggarisbawahi kekuatan lingkungan berdasar: (a) keunikan, (b) intensitas, maupun (c) frekuensi (seperti halnya penilaian need hero), dan

3. mencatat ketidakmunculan elemen-elemen tertentu, khususnya : obyek-obyek fisik dan obyek-obyek manusia (karakter lain) yang tidak ada di gambar tetapi dimunculkan karena imajinasi pembuat cerita

4. beri tanda sifat-sifat orang-orang yang dihadapi hero : apakah mereka sebagian besar tampak ramah atau tidak ? apakah wanita terlihat lebih ramah daripada laki-laki ? bagaimana sifat wanita yang lebih tua (figur ibu) dalam cerita ? maupun laki-laki lebih tua (figur ayah) ?

Ada beberapa kekuatan-kekuatan lingkungan (press) yang dibuat dalam daftar, berdasar pengaruh mereka (atau yang berpotensi mempengaruhi) pada hero.

Berikut daftar press dengan kekuatannya :

(1) P. Affiliasi (terdiri dari : Asosiatif dan Emosional), (2) P. Agresi (terdiri dari : Emosional dan verbal, Fisik- Sosial, Fisik- Asosial , Perusakan hak milik), (3) P. Dominance (terdiri dari : Coercion / Paksaan, Restraint / Larangan, Inducement, Seduction / Ajakan), (4) P. Nurturance, (5) P. Rejection, (6) P. Lack, Loss (terdiri dari : Lack dan Loss), (7) P. Physical Danger (terdiri dari : Active dan Insupport), (8) P. Physical Injury.

(catatan : keterangan masing-masing press bisa dilihat di halaman lampiran)

Kekuatan masing-masing press yang ada dalam cerita diberi skor antara $1-5$, dan 5 merupakan skor tertinggi yang 
bisa diberikan untuk masing-masing cerita. Kriteria pemberian skor kekuatan press didasarkan pada (1) intensitas, (2) durasi, (3) frekuensi, dan (4) general significance press dalam cerita.

Setelah memberi nilai pada ke 20 cerita, maka total skor untuk masing-masing press dibandingkan dengan skor standar sesuai dengan usia dan jenis kelaminnya.

Harus dipahami bahwa satu kekuatan lingkungan seringkali mengandung campuran dari dua (2) atau bahkan lebih dari dua press yang berbeda.

\section{Interes dan sentiment}

Aspek ini digunakan bila ditemukan atribut ini menempel pada hero. Atribut penting yang ada antara lain :

a. Kateksis positif atau negatif ( berkaitan dengan nilai, appeal )

b. Wanita yang lebih tua ( berkaitan dengan figur ibu )

c. Pria lebih tua ( berkaitan dengan figur ayah)

d. Sama jenis kelamin, baik laki-laki atau perempuan (berkaitan dengan figur sibling )

\section{Tema}

Interaksi antara hero's need (atau gabunganbeberapa need) dengan environmental press (atau gabungan beberapa press) membentuk sebuah tema sederhana. Kombinasi beberapa tema sederhana akanmembentuk sequence atau tema-tema kompleks. 
Dengan memisahkan hero dengan lingkungan, kita akan mendapat gambaran lebih jelas apakah hero memiliki sejumlah kecemasan yang tidak wajar, ataukah lingkungannya didominasi oleh orang-orang yang mengancamnya.

Kemungkinan lainnya adalah membuat analisis secara keseluruhan tanpa memberi skor pada masing-masing variabel, yaitu dengan memperhatikan setiap cerita secara keseluruhan, dan mencari tema besar dan kecilnya, plot dan sub-plotnya. Ada beberapa tema yang umum, misal, tema yang berkisar tentang : prestasi, rivalry, cinta, deprivasi, konflik keinginan, eksplorasi, perang, dan sebagainya.

\section{Outcome}

Bagian penting selanjutnya yang harus diperhatikan interpreter adalah perbandingan kekuatan-kekuatan yang berasal dari hero dengan kekuatan-kekuatan yang berasal dari lingkungan. Seberapa besar kekuatan (energi, determinasi, usaha, kompetensi) yang dimunculkan hero ? Bagaimana perbandingan kekuatan-kekuatan lingkungan yang memberi keuntungan atau memfasilitasi dengan kekuatan yang bertentangan atau yang menyakiti ? Sulit atau mudahkan hero meraih prestasi ? Saat menghadapi kekuatan yang bertentangan, apakah hero melakukan perlawanan atau kolaps ? Dalam kondisi bagaimana hero mengalami kegagalan ?dan seterusnya.

Dengan mengamati tiap peristiwa, tiap interaksi antara press dan need, dari sudut pandang hero, seorang interpreter harus menghitung berapa banyak mengalami peristiwa yang menimbulkan frustrasi, derajat kesuksesan dan kegagalan, berapa rasio akhir cerita yang bahagia dan tidak bahagia. 
Teknik analisis dengan model dari Murray ini ada yang menganggap tidak praktis dan makan banyak waktu lama, sehingga model penyekorannya maupun model interpretasi original dari Murray ini menimbulkan banyak variasinya.

\section{Teknik Henry}

\section{ANALISA BENTUK DAN ISI CERITA}

Menurut Henry, untuk mengungkap kepribadian dan dinamikanya pemeriksa bisa melakukan analisa terhadap bentuk dan isi cerita yang dihasilkan dari tes TAT (Sukadji, 1982). Oleh karena itu Henry menyusun langkah-langkah interpretasi terhadap hasil tes sebagai berikut :

1. Mengetahui persepsi testee terhadap stimulus yang dihadapi.

2. Mengetahui bagaimana respon testee terhadap stimulus .

3. Memahami persepsi terhadap stimulus dan reaksinya terhadap stimulus.

Berikut kita bahas analisa bentuk dan isi cerita dalam teknik Henry untuk mendapat gambaran kepribadian dan dinamikanya.

\section{a. Analisa Bentuk}

Bentuk cerita yang diberikan testee bisa sangat bervariasi antara satu testee dengan testee lainnya. Hal ini bisa terjadi karena bervariasinya persepsi dan organisasi testee saat suatu stimulus diberikan, serta bervariasinya cara testee menanggapi suatu stimulus di lingkungannya atau dari dalam dirinya sendiri : 
a. Kualitas dan kuantitas

1. Panjang cerita

Panjang cerita bukan mengindikasikan cerita testee bisa dinterpretasi, tetapi menggambarkan kalau testee memiliki kelancaran berbicara dan menemukan katakata.

2. Kuantitas isi

Hal yang dilihat adalah banyak tidaknya gambaran kejadian, insiden, atau elaborasi yang terungkap dalam cerita yang dibuat testee.Apabila ada banyak variasi isi cerita mengindikasikan luasnya interes, kekayaan daya khayal, dan kemudahan didalam membuat asosiasi.

3. Kualitas isi

Apakah isi cerita memiliki pola yang bervariasi atau tidak. Selanjutnya lihat : interpretasi isi.

4. Kejelasan dan kekayaan imajinasi

Hal yang mendukung interpretasi adalah apakah penggambaran ceritanya secara dramatis, atau biasabiasa saja, atau hanya mendeskripsikan gambar secara terinci. Penggambaran tokoh pahlawan merupakan penggambaran testee tentang diri sendiri, sehingga gambaran tokoh pahlawan yang tidak riil mengindikasikan testee kurang realistis didalam memandang dirinya.

5. Ritme dan kelancaran 
Kelancaran testee bercerita atau mengungkapkan kata-kata, tidak sering berhenti, dan tidak ada kontradiksi, serta tidak berubah-ubah pendirian.Adanya ketidaklancaran, ragu-ragu, berhenti, memberi komentar, atau mengkritik, mengindikasikan adanya inkonsistensi, usaha menyensor diri.

b. Kualitas Organisasi

1. Kualitas ketiga bagian pokok cerita

Adanya ketiga bagian pokok cerita yang harus ada ( yaitu : awal, yang sedang terjadi, dan akhir cerita) menunjukkan testee memiliki kemampuan dan kemauan menjalankan instruksi.

Kenyataannya, ada testee yangtelah memahami instruksi tester tetapi cerita yang dibuat menekankan salah satu bagian pokok cerita :

(a) penekanan pada kejadian sebelumnya, maka hal ini berarti adanya preokupasi pada masa lalu testee. Penekanan ini dapat berbentuk deskripsi atau ide pokok ;

(b) penekanan pada akhir cerita berarti kurang ada kontak dengan realitas, testee cenderung kurang memperhatikan hal-hal yang berkaitan dengan masa lalu dan keadaan sekarang didalam membuat rencana masa depan ;

(c) terlalu menekankan pada kejadian yang sedang berlangsung serta terlalu banyak menyebut detil yang ada dalam gambar menandakan testee tidak memiliki perspektif tentang kehidupan, terlalu bergantung pada kepastian. 
2. Tingkat organisasi

Ada beberapa tingkat cara testee mengorganisir stimulus-stimulus menjadi suatu konsep cerita, yaitu :

(a) membuat "daftar" kenyataan yang ada dalan gambar (hanya deskripsi). Cara ini biasa dilakukan oleh testee yang taraf kecerdasannya rendah atau mengalami gangguan mental ;

(b) menggambarkan kenyataan yang ada dalam gambar sesuai dengan arti dan hubungannya. Cara ini juga dilakukan ole testee yang taraf kecerdasannya rendah atau mengalami gangguan mental ;

(c) menggunakan imajinasi (pandangan-pandangan pribadi) untuk menghidupkan deskripsi.

3. Kesesuaian dan logika

Hal yang perlu diperhatikan dalam cerita testee adalah urutan penyajian obyek dan ide, serta kecocokan dan keserasian obyek dan ide. Ada kemungkinan, seorang testee :

(a) mampu bercerita dengan konsistensi internal yang baik, tetapi berdasar premis-premis yang salah,

(b) mampu menginterpretasi detil-detil gambar secara akurat, tetapi dijadikan elaborasi cerita yang tidak berhubungan dengan keseluruhan cerita.

4. Konsep menyeluruh

Pada dasarnya, ada testee yang hanya menggunakan sebagian stimulus-stimulus, tetapi tidak sedikit yang mengintegrasikan seluruh stimulus-stimulus menjadi suatu konsep pokok yang terpadu. Cerita yang 
menggunakan konsep secara menyeluruh dan terpadu (terintegrasi secara logis) membutuhkan tingkat kecerdasan yang tinggi, dan hanya bisa dilakukan oleh testee yang memiliki kecerdasan tinggi.

Ada 2 (dua) cara yang digunakan testee untuk menyusun konsep cerita secara keseluruhan, yaitu :

(a) menyusun cerita secara menyeluruh dahulu, dan dilanjutkan dengan menyusun cerita secara terperinci ; atau

(b) mendahulukan rincian-rincian cerita, dan dilanjutkan penyusunan cerita secara keseluruhan

Testee yang mampu memasukkan figur-figur pokok ke dalam cerita menggambarkan testee :

(a) memiliki kemampuan menangani stimulus-stimulus lingkungan umum secara normal,

(b) cukup mampu untuk berorientasi pada realitas, sehingga testee terlihat luwes didalam melakukan kompromi dan menangani konsep-konsep sosial nya.

Pada testee yang terlalu memperhatikan detil, sering mengindikasikan bahwa ia lebih terikat pada hal-hal yang kecil-kecil atau memiliki preokupasi tertentu.

\section{b. Analisa Isi cerita}

Secara umum, isi cerita yang disampaikan testee bida dilihat dari 3 (tiga) segi dasar, yaitu meliputi :

A. Segi isi positif

Pada segi ini, yang kita lihat adalah : 
1. Nada emosi cerita secara umum

Nada emosi cerita biasanya terlihat dari penggunaan kata-kata di dalam jalan cerita yang disusun testee, apakah ceritanya bernada positif atau negatif. Secara spesifik, nada ini bisa dirasakan dengan membaca awal dan akhir cerita.

Pada umumnya, nada emosi ini terdiri dari nada positif atau negatif, nada konflik, atau nada keserasian hubungan interpersonal.

Perkiraan tentang nada emosi secara umum bisa kita dapatkan dengan cara : membaca terlebih dahulu ceritanya, dilanjutkan dengan menganalisis setiap cerita secara terperinci.

2. Pokok jalan cerita

Pokok jalan cerita disini sama artinya dengan tema (dalam teknik Murray), dan tersusun atas :

(a) deskripsi latar belakang lingkungan pada tokoh didalam cerita testee

(b) keadaan pribadi, emosi, keinginan, maupun kebutuhan pelaku ;

(c) stimulus-stimulus yang dihadapi para pelaku ;

(d) reaksi-reaksi yang ditunjukkan para pelaku atas stimulus tersebut ;

(e) hasil akhir dari interaksi antara tuntutan situasi dengan tanggapan bermotif.

3. Tokoh pahlawan

Penggambaran tokoh pahlawan termasuk yang perlu dianalisis. Tokoh pahlawan yang ada dalam cerita ditinjau dalam hal minat, kemampuan dan adekuasi, 
juga motif yang dimiliki tokoh, serta atribut-atribut psikis lainnya, seperti : konflik, kecemasan, dsb.

4. Tokoh lain yang dimasukkan dalam cerita Didalam cerita yang dibuat testee, hampir selalu ada tokoh lain yang dilibatkan. Tokoh-tokoh lain ini bisa dianalisis untuk kepentingan interpretasi.

Hal penting yang bisa dianalisis dari tokoh-tokoh lain yang dimasukkan dalam cerita adalah yang berkenaan dengan atribut fisik, psikis (misal : motif, emosi, perjuangan, dsb.), maupun hubungan manusiawinya, serta reaksi tokoh terhadap atribut lingkungan.

5. Hubungan interpersonal

Disini, kita melakukan interpretasi pada :

(a) tanggapan yang berbentuk pikiran dan tindakan hero di berbagai situasi interpersonal dengan tokoh-tokoh lain ;

(b) kuantitas dan kualitas interaksi antar para pelaku, yaitu sejauh mana pelaku-pelaku terlibat dala interaksi dengan sesamanya ;

(c) penggunaan emosi sebagai dasar interaksi

B. Segi struktur dinamika isi

Pada segi ini, ada 2 (dua)hal yang dilihat, yaitu :

1. Interpretasi simbol, yaitu interpretasi untuk simbolsimbol yang muncul dalam cerita. Hal ini tidak mudah, sehingga didalam melakukan interpretasi harus diperhatikan : adanya bukti pendukung bahwa benda-benda itu dipakai sebagai simbol, dan kunci 
dari arti simbol tersebut harus bisa ditemukan dalam cerita tersebut.

2. Interpretasi asosiasi, yaitu interpretasi pada asosiasi yang muncul dalam cerita. Adakalanya ditemukan asosiasi antara 2 (dua) topik yang tidak ada hubungan yang logis, meskipun banyak juga ditemukan asosiasi yang logis antar 2 (dua) topik

\section{Segi isi negatif}

Selain isi positif, yang juga dilihat adalah isi negatif.Ada perbedaan analisis kita pada isi positif dan isi negatif.

- Pada analisis isi positif, kita mencoba untuk meninjau isi cerita seperti yang dikatakan testee.

- Pada analisis isi negatif, kita mencoba meninjau halhal yang tidak dikatakan testee tentang hal-hal yang diharapkan akan dikatakan testee.

Analisis isi negatif biasanya didasarkan pada pengetahuan interpreter tentang : (1) karakteristik kartukartu yang diberikan ; (2) identitas stimulus yang dimaksudkan ( misal : apa / siapa yang terlibat dalam cerita ) ; (3) ungkapan emosi yang ditimbulkan (emosi laten)

Isi negatif sebenarnya menunjukkan :

(1) kegagalan atau kekeliruan testee untuk menggunakan isi (secara normal), serta hubungan yang ada dalam gambar ;

(2) bentuk penolakan, baik terhadap kartu juga terhadap adanya stimulus latent. Adanya penolakan ini bisa dilihat dari : penggunaan simbol benda yang ditolak, asosiasi dinamika hubungan testee dengan simbol, 
atau adanya dukungan pada hal-hal tersebut dalam bagian lain dalam cerita.

\section{INTERPRETASI HASIL TES}

Interpretasi hasil tes dengan menggunakan teknik Henry bisa mengungkap beberapa aspek, dan semua tersusun dalam kerangka interpretasi Teknik Henry seperti di bawah :

Aspek I : PENDEKATAN MENTAL

Aspek II : PROSES IMAJINASI

Aspek III : DINAMIKA KELUARGA

Aspek IV : PENYESUAIAN TERHADAP DIRI SENDIRI

Aspek ini meliputi pengungkapan :

(a) Sikap emosi dasar (termasuk didalamnya adalah kekuatan dan arah penyelesaian masalah, apakah pasif/asertif/agresif) :

$\rightarrow$ Ini menggambarkan penggunaan energi psikis atau aspek emosi didalam penyelesaian masalah pribadi atau penyelesaian konflik yang dialami testee.

Sikap emosi dasar ini bisa diungkap dari :

(1) penggunaan bahasa dan tindakan yang asertif, atau se-baliknya ;

(2) outcome atau pemecahan masalah bentuknya konstruktif dan progresif, atau dependen dan minta bantuan ;

(3) apakah dalam cerita, hero cenderung konstruktif dan per-caya diri, atau pasrah dan nrimo. 
(b) Sikap terhadap impuls of life:

Apakah impuls of life diterima atau ditolak. Adanya kesadaran testee akanimpuls of life ditunjukkan pada pengungkapan perasaan dan motivasi pribadi di ceritanya.

Testee yang menerima impuls of life nya diwakili oleh cerita yang menggambarkan perasaan dan motivasi ini mengarah pada outcome positif dan sukses.

(c) Kecemasan

Ada tidaknya kecemasan pada diri testee bisa terlihat dari adanya gangguan pada konsistensi cerita, kegoyahan hal-hal yang dipentingkan, adanya penolakan, atau adanya penggambaran - penggambaran eksplisit atau implisit dalam cerita.

(d) Kekuatan ego dan pertahanannya :

Ini mewakili cara testee menyesuaikan diri dan bertindak untuk melindungi diri dari perasaan tidak aman, dalam bentuk penggunaan defens mekanisme atau caracara lain untuk menghibur diri.

(e) System control (conscious, inner dan outer control):

(1) Bila dalam cerita, hero dapat mengintegrasikan aturan - aturan dan larangan dengan impuls dan keinginan, maka ini indikasi outer control nya 
memadai, testee memahami perlunya kompromi dalam hidup bermasyarakat ;

(2) Bila dalam cerita, hero fanatik didalam mengikuti aturan dan larangan, indikasi adanya kontrol yang melemah, yang mengindikasikan testee kehilangan spontanitas, semua yang dikerjakan semata-mata karena tekanan dari luar ;

(3) Bila dalam cerita, hero bisa mengontrol kejadian-kejadian di luar dirinya sesuai dengan kebutuhan dan keinginannya, mengindikasikan inner control - nya adekuat, testee bisa menerima impuls of life yang berkualitas.

(f) Pendekatan emosional didalam hubungan interpersonal :

Kuantitas dan kualitas ikatan dengan orang lain dapat diketahui dari :

(1) banyaknya aktivitas interpersonal yang digambarkan dari seluruh cerita yang disampaikan testee ;

(2) insight tentang motivasi yang ada dalam cerita, apakah ada empati terhadap tokoh-tokoh yang diceritakan ?, apakah motivasinya saling berkaitan ?;

(3) manusia, benda, dan situasi yang dilibatkan dalam cerita.

(g) Kematangan dan keseimbangan emosi. 
Aspek V : REAKSI EMOSI

Aspek ini mengungkap :

(a) spontanitas didalam menanggapi stimulus emosi ;

(b) spontanitas dalam kebebasan bertindak secara obyektif.

Selain itu bisa juga diketahui :

(a) apakah testee lebih bereaksi pada stimuli dari luar diri atau dari dalam diri sendiri ;

(b) apakah testee lebih mementingkan keadaan di luar diri atau pada perasaan-nya dan reaksinya terhadap perasaannya.

Aspek VI : PENYESUAIAN SEKSUAL

Aspek ini berusaha mengungkap :

(a) kematangan ;

(b) kecemasan dalam segi seksual ;

(c) persepsi peran

Aspek VII : PENDEKATAN BEHAVIOR

Aspek ini meliputi :

(a) pola perilaku yang dapat diamati ;

(b) hubungan dengan teman sebaya ;

(c) hubungan dengan otoritasorang tua atau orang dewasa ;

(d) penyesuaian diri dengan sekolah atau tempat kerja ;

(e) problem-problem perilaku khusus. 
Aspek VIII : KESIMPULAN DESKRIPTIF dan INTEGRATIF

Fokus perumusan kesimpulan ditentukan oleh

tujuan penggunaan TAT. Di bidang klinis, misal, di kesimpulan disajikan :

(a) simptomatologi, dinamika dan genetika dari masalah yang dihadapi klien.

(b) informasi apa yang dibutuhkan, maka informasi itu saja yang dimasukkan.

\section{Teknik Kesan}

Teknik ini merupakan teknik interpretasi paling sederhana. Pemeriksa melakukan pengamatan sepintas atas cerita yang ada. Dilanjutkan dengan membaca berulang kali cerita-cerita yang diberikan testee. Teknik ini bisa dipakai untuk keperluan-keperluan tertentu (misal : untuk screening)

Secara keseluruhan, prosedur yang bisa diikuti pemeriksa bila menggunakan teknik ini adalah :

1. Pertama-tama, membaca seluruh cerita dari semua kartu yang disajikan untuk memperoleh gambaran umum yang akan dijadikan sebagai kerangka berpikir ketika menganalisis lebih mendalam, karena ada anggapan suatu cerita itu adalah bentuk komunikasi kondisi psikologis seseorang. Contoh :

$\rightarrow$ Saat membaca pertama kali, akan didapatkan kesan bahwa cerita testee cenderung bernada emosi negatif. Membaca lagi secara lebih cermat. Pemeriksa bisa memberi tanda (misal: garis merah) situasi-situasi tertentu dimana emosi tersebut timbul, juga kata-kata yang mempunyai muatan penting sebagai petunjuk adanya emosi negatif tersebut. Hary (2011), memberi saran 
dengan cara menggarisbawahi hal-hal yang menarik, bermakna, khas, dan unik .

2. Dilanjutkan membaca untuk kedua kalinya. Di sini diharapkan pemeriksa akan memperoleh kesan, misal : testee menunjukkan kecemasan ketika menghadapi orangorang yang memiliki otoritas.

3. Membaca untuk ketiga kalinya. Di sini, pemeriksa bisa memberi tanda lagi hal-hal penting yang menunjukkan adanya kecemasan dan defens- mekanisme, misal :

$\rightarrow$ Diperoleh kesimpulan bahwa kecemasan berkaitan dengan situasi kompetisi, sedang bentuk defens-nya adalah rasionalisasi.

4. Membaca lagi. Sekali lagi, pemeriksa membaca semua cerita untuk memperoleh kesimpulan umum. Kemudian menyimpulkan :

- Kebutuhan apa yang dimiliki subyek,

- Bagaimana subyek mempersepsi lingkungannya,

- Keadaan emosi yang dialami subyek (sebagai akibat adanya kondisi/lingkungan),

- Bagaimana super-ego dan ego subyek,

- Defens mekanisme subyek, dsb.

Teknik kesan ini disarankan dilakukan oleh orang yang telah cukup banyak memiliki pengalaman dalam menggunakan TAT, karena pengalaman akan menentukan akurasi interpretasi hasil tesnya.

\section{B. CAT}

Pada tahap interpretasi, Bellak membuat sendiri "Short Form T.A.T and C.A.T Blank" yang dimaksudkan untuk memfasilitasi proses analisis dan mencatat cerita. Form analisis ini 
bisa digunakan sebagai frame of reference, khususnya bagi pemula atau bagi yang sudah berpengalaman karena form ini sangat bermanfaat.

Pada "Short Form T.A.T and C.A.T Blank", ada 10 variabel yang harus digali dari setiap cerita yang diberikan testee anakanak, meliputi :

1. tema utama

2. tokoh utama (hero)

3. kebutuhan dan dorongan utama dari hero

4. konsep utama tentang lingkungan (dunia)

5. Figur-figur dilihat sebagai .......

6. Konflik-konflik yang signifikan

7. Sifat dari kecemasan

8. Defens utama melawan Konflik dan Ketakutan

9. Adekuasi Super ego seperti yang ditunjukkan pada "pemberian hukuman atas kejahatan

10. Integrasi Ego

Selanjutnya akan dibahas masing-masing variabel tersebut sehingga bisa digunakan untuk pegangan didalam melakukan analisis untuk setiap cerita yang disampaikan testee anak-anak selama tes berlangsung.

\section{Tema Utama}

Tema utama adalah kecenderungan umum tema ceritacerita yang dibuat testee anak-anak. Dalam interpretasinya, harus ditemukan pola perilaku yang umum diceritakan.

Pada anak-anak usia 3-4 tahun tema utamanya lebih sederhana. Suatu cerita bisa muncul lebih dari satu, dan tematema yang ada kadang-kadang saling berhubungan. 


\section{Tokoh utama (hero)}

Hero adalah figur yang sering diceritakan, yang mirip testee dalam hal usia dan jenis kelamin, dan peristiwa yang ada dalam cerita dilihat dari sudut pandang hero. Figur dalam cerita mewakili diri testee sebagai tokoh utama (hero).

Hero dalam cerita bisa ada lebih dari satu dan testee mengidentifikasi dirinya pada kedua hero, atau awalnya pada satu hero kemudian kepada hero lain. Kemungkinan ada kelainan, dimana testee mengidentifikasi hero dengan jenis kelamin berbeda, dan ini harus menjadi catatan.

Kadang, identifikasi kepada figur kedua lebih mendalam. Hal ini mungkin disebabkan karena minat, harapan yang ada pada diri testee dimasukkan dalam diri hero, dan ini harus menjadi catatan.

\section{Kebutuhan dan dorongan utama dari hero}

(a) Behavioral needs dari hero (seperti dalam cerita)

Kebutuhan yang dimunculkan dalam cerita menggambarkan kebutuhan testee dalam kehidupan sehari-hari, atau kebalikannya dan menjadi angan-angan yang diinginkan. Misal, cerita yang

(b) Figur, obyek, atau lingkungan yang dimasukkan dalam cerita Apabila testee memasukkan obyek seperti senjata dalam cerita berarti ada kebutuhan akan agresi. Kalau memasukkan makanan dalam cerita (meskipun tidak dimakan) mewakili kebutuhan untuk mendapat kepuasan oral. Apabila memasukkan figur atau situasi yang tidak ada dalam gambar, maka di analisis sheet harus diberi tanda seru. Situasi eksternal, seperti : ketidakadilan, kekerasan, dsb. sebenarnya mewakili lingkungan dimana testee tinggal.

(c) Figur, obyek, atau lingkungan yang ada dalam gambar tetapi diabaikan. 
Bila ini ada berarti ada permusuhan yang jelas terjadi, atau figur atau obyek tersebut menimbulkan konflik.

\section{Konsep tentang lingkungan (dunia)}

Lingkungan adalah keadaan yang ada di luar diri, yang mewarnai inti cerita, berupa : manusia, atau lingkungan fisik di luar tokoh utama (hero).

Konsep tentang lingkungan adalah percampuran antara persepsi diri yang tidak disadari dengan distorsi appersepsi stimuli karena adanya jejak-jejak ingatan di masa lalu. Beberapa konsep tentang lingkungan dimana tokoh berada, antara lain :

\begin{tabular}{|l|l|}
\hline \multicolumn{2}{|c|}{ konsep-konsep tentang lingkungan : } \\
\hline - penuh pertolongan & - terkontrol \\
\hline - kejam & - membosankan \\
\hline - agresif & - kacau \\
\hline - eksploitatif & - kotor \\
\hline - ramah & - membingungkan \\
\hline - berbahaya & - penuntut \\
\hline - rakus & - menekan, dsb. \\
\hline
\end{tabular}

\section{Figur-figur dilihat sebagai .......}

Bellak memandang gambar-gambar dalam kartu CAT sebagai serangkaian situasi sosial, dimana terjadi interaksi interpersonal. Oleh karena itu, di masing-masing kartu perlu dilihat bagaimana hero bersikap (melihat dan bereaksi) terhadap orang-orang atau obyek yang ada di sekitarnya, yang disesuaikan menurut kelompok umur, yaitu :
a. Figur orang tua
b. Figur sebaya
c. Figur lebih muda 
Figur-figur tersebut di atas digambarkan secara umum dengan figur yang bersifat, antara lain :

\begin{tabular}{|l|l|}
\hline \multicolumn{2}{|c|}{ Hero memandang figur memiliki sifat : } \\
\hline - Memberi nasehat/ perintah/ hukuman/ pembatasan \\
\hline - Supportif & - Kompetitif \\
\hline - Lemah & - Agresif \\
\hline - Kurang mampu & - kotor \\
\hline - Pasif & - menolak, dsb. \\
\hline
\end{tabular}

Reaksi hero mencerminkan bentuk pertahananpertahanannya (defens mekanisme) yang merupakan upaya hero untuk menanggapi atau mengkompromikan kebutuhan-kebutuhannya selama berhubungan dengan orang lain, antara lain :

\begin{tabular}{|l|l|}
\hline \multicolumn{2}{|c|}{ Reaksi Hero terhadap figur } \\
\hline - Lari ke alam fantasi & - Ada kemarahan \\
\hline - Ambivalen / mendua & - Penarikan diri \\
\hline - Ada perasaan bersalah & - Upaya mencapai otonomi \\
\hline - Depresi & - Pemberontakan \\
\hline - Agresi & - Perlawanan, dsb. \\
\hline
\end{tabular}

\section{Konflik-konflik yang signifikan}

Konflik-konflik yang bisa terjadi antara :

a. Dorongan dengan dorongan, misal :

- doronganberprestasi vs dorongan kesenangan

- dorongan otonomi vs dorongsn ketaatan

- dorongan passivity vs dorongan counteraction (dorongan untuk malas setelah melakukan sedikit usaha vs dorngan untuk mencoba dan mencoba lagi) 
b. Struktur kepribadian dengan agresi, misal :

- super ego vs agresi

c. Need dengan press, misal :

- understanding vs restraint (kebutuhan untuk mendapat pendidikan vs orang tua melarang)

\section{Hakekat dari Kecemasan}

Kecemasan adalah kekhawatiran yang tidak ada dasarnya atau alasan nyata. Ada beberapa macam kecemasan yang mungkin dialami testee anak-anak :

a. Kecemasan akan adanya bahaya fisik atau hukuman.

b. Kecemasan bahwa tindakannya tidak disetujui.

c. Kecemasan akan kehilangan cinta.

d. Kecemasan akan ditinggal, dibiarkan (baik secara fisik maupun emosional).

e. Kecemasan akan penyakit.

f. Kecemasan akan kekurangan / kemiskinan.

g. Kecemacan akan dikalahkan (tidak berdaya).

h. Kecemasan akan dimusnahkan

\section{Defens utama melawan Konflik dan Ketakutan}

Ego Defens digunakan untuk mengatasi dorongan. Analisis terhadap ego defens ini akan bisa mengetahui dorongan yang dimiliki testee, dan defens itu berkaitan dengan perilaku overt.

Contohnya :

- Beberapa subyek memilih defens mekanisme obsesif dalam menghadapi gambar-gambar yang tidak menyenangkan, sehingga mereka membuat 4 atau 5 tema untuk setiap cerita yang dibuat cenderung pendekpendek dan bersifat deskriptif (hanya menyebut satu persatu gambar yang ada, tidak membuat cerita). Hal ini, 
secara manifestasi berbeda, tetapi secara dinamik identik.

\section{Adekuasi Super ego seperti yang ditunjukkan pada "pemberian hukuman atas kejahatan"}

Hukuman terhadap kejahatan adalah sejauh mana superego memberi hukuman pada ego yang telah melakukan tindakan (yang melanggar aturan super ego) dalam rangka memuaskan id.

Hal-hal yang perlu diperhatikan adalah : apakah perbuatan-perbuatan dalam cerita dianggap sebagai kejahatan atau tidak. Ada perbuatan yang sebenarnya merupakan kejahatan, tetapi oleh subyek dianggap permainan, misal : cerita tentang film-film cowboy.

Dalam menilai hukuman, harus dilihat dari sudut pandang moril subyek. Berat ringannya hukuman memberikan insight tentang kualitas super ego.

a. Hukuman adil menunjukkan subyek memiliki jalan pikiran yang seimbang.

b. Hukuman lunak atau jarang memberi hukuman : menunjukkan indikasi psikopat.

c. Hukuman yang keras : terlihat pada subyek yang neurotik

d. Hukuman yang sangat berat atau sangat ringan : menunjukkan super ego yang tidak terintegrasi dan juga neurotik.

\section{Intergrasi ego}

Integrasi ego menunjukkan sejauh mana subyek mampu berfungsi secara baik. Hal ini bisa diketahui dengan cara mengkonfrontasikan gambar dengan bagaimana appersepsi subyek tentang stimulus gambar tersebut. 
Karakteristik formal yang perlu diperhatikan berkaitan dengan kekuatan ego (ego-strength), yang meliputi :

a. Apakah subyek mampu membuat cerita dengan memperhatikan aspek adaptif dari stimulus secara layak, ataukah mengabaikan stimulus, atau membuat cerita yang tidak ada hubungannya dengan gambar karena subyek kurang memahami realitas atau sangat terikat dengan masalahnya sendiri dan membiarkan masalahnya di luar.

b. Bagaimana cara subyek mengatasi kecemasan ? apakah dengan cara membuat cerita secara stereotip, inteligen, kreatif, original ?

c. Plot cerita yang dihasilkan. Bagaimana cara pemecahan /solusi konfliknya ? apakah tepat, komplit, realistik, terstruktur, aneh/bizarre?

d. Harus diperhatikuan juga, seberapa jauh jarak subyek dengan cerita yang dibuat?

- Jika setting cerita terjadi di tempat yang jauh, terjadi sekian tahun yang lalu, hero hanya sebagai penonton, atau cerita berasal dari film, situasi emosional dilukiskan secara sarkastik, maka ini indikasi usaha subyek menggunakan defens mekanisme isolasi.

- Jika subyek melibatkan diri dalam cerita secara personal, misal : subyek berkata "... hal ini seperti yang terjadi pada diri saya", maka ini indikasi ada kecenderungan narsistik.

Dalam tes proyektif seperti CAT, tidak ada jawaban yang benar atau salah, sehingga tidak ada skor angka, kecuali mencatat esensi dari masing-masing cerita-cerita dan menunjukkan ada atau tidaknya unsur tematik 
tertentu pada form yang tersedia. Seperti pada CAT, setiap cerita dengan hati-hati dianalisis untuk mengungkap mendasari kebutuhan, konflik, emosi, sikap, dan pola respon anak. 


\section{BIODATA PENULIS}

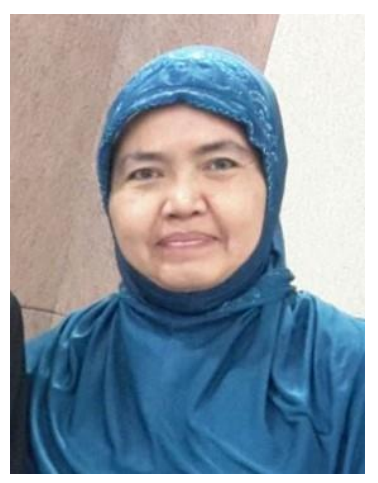

Dra. Dwi Nastiti M.Si. Psikolog., lahir di Mojokerto,19 Oktober 1963. Pendidikan tinggi S-1 ditempuh di Universitas Surabaya, lulus September 1987, sedangkan S-2 ditempuh di Universitas 17 Agustus 1945 di Surabaya, lulus Januari 2008. Sejak tahun 1988 penulis telah berkecimpung di dunia pendidikan, terutama di perguruan tinggi sebagai dosen psikologi. Di tahun 1988 - 2008 menjadi dosen tetap di Fakultas Psikologi Universitas Putra Bangsa Surabaya, dan sejak tahun 2010 sekarang menjadi dosen tetap di Fakultas Psikologi Universitas Muhammadiyah Sidoarjo dengan jabatan fungsional Lektor Kepala. Kegiatan penelitian mandiri dilakukan sejak tahun 1999 dan publikasinya lebih banyak di jurnal ilmiah psikologi. Sejak tahun 2010 di Universitas Muhammadiyah Sidoarjo, 3 penelitian di 5 tahun terakhir terkait dengan masalah Bimbingan Konseling, Adversity Quotient, dan Koping Stres, serta publikasinya di jurnal ilmiah dan presentasi di seminar nasional. Penulis telah membuat materi-materi kuliah sejak tahun 1988 terdorong oleh terbatasnya literatur psikologi dalam bahasa Indonesia sesuai dengan mata kuliah yang diampu, salah satunya adalah TAT dan CAT, sebagai salah satu bentuk Tes Appersepsi, hanya saja masih dalam bentuk diktat, dan penyusunan materi perkuliahan masih terus dilakukan penulis sampai saat ini. Alamat e-mail penulis : nastitidwi19@yahoo.co.id 


\section{DAFTAR PUSTAKA}

Anastasi, A. 1968 .Psychological Testing third edition. New York : Mc.Millan Publishing Co.Inc

Anastasi, Anne \& Susana Urbina, 1997. Tes Psikologi. Psychological Testing. Terjemahan Dobertus Hariono S. Imam, 2007. Jakarta. Penerbit PT Indeks.

Bellak, L,M.D, 1975. The Thematic Apperception Test, The Children's Apperception Test, and The Senior Apperception Technique in clinical use. Third Edition, Grune \& Stratton New York.

Cohen, R.Jay \& Mark E,Swerdlik. 2005. Psychological Testing and Asessment. An Introduction to Tests and Measurement. The McGraw-Hill Companies, Inc. New York, America.

Freidenberg, Lisa, 1995. Psychological Testing. Design, Analysis, and Use. Asimon \& Schuster Company, Needlam, Heights, Massachusetts, USA.

Gunarsa, S.D., 2004. Manual Tes Gambar CAT-AI. Penerbit LPSP3 Fakultas Psikologi UI.

Hary, TA. P., 2011. Efektivitas Thematic Apperception Test Dalam Penanganan Kasus Klinis. Jurnal SPIRITS, Vol.1, No.2, Mei 2011. Online

Marnat, G.G., 2009. Handbook of Psychological Assessment. Fifth Edition. Alih bahasa Drs. Helly P.S, MA., Dra. Sri M.S., 2010. Penerbit Pustaka Pelajar, Yogyakarta.

Murray. 1987. Thematic Apperception Test Manual. Alih bahasa : Sianawati Hidayat. 
Nastiti, D, 2013. Psikologi Proyeksi (Pengantar Memahami Kepribadian Secara Akurat). Diktat. Universitas Muhammadiyah Sidoarjo.

Santrock, J.W., 2009. Psikologi Pendidikan. Educational Psychology(edisi ketiga). Jakarta: Salemba Humanika.

Semednoff, Boris. 1976. Projective Techniques. John Willy \& Son.

Soetarlinah, Soekadji. 1982. TAT dan Penggunaannya. Fakultas Psikologi UGM.

Gambaran Thematic Apperception Test pada subjek yang mengalami ketergantungan heroin dengan mengkaji pola keluarga dan penyesuaian keluarga. Tesis. Universitas Indonesia Library, UI. Deskripsi Dokumen: http://lib.ui.ac.id/bo/uibo/detail.jsp?id=20343422\&lokasi=I okal. 


\section{Lampiran}

\section{Gambar-gambar Kartu CAT-A.I}

Kartu 1-A.I : Tiga ekor anak ayam sedang duduk mengelilingi meja dengan bakul nasi di atasnya. Seekor anak ayam tidak memakai kain lap. Seekor ayam dewasa berdiri di latar belakang yang tergambar samar-samar

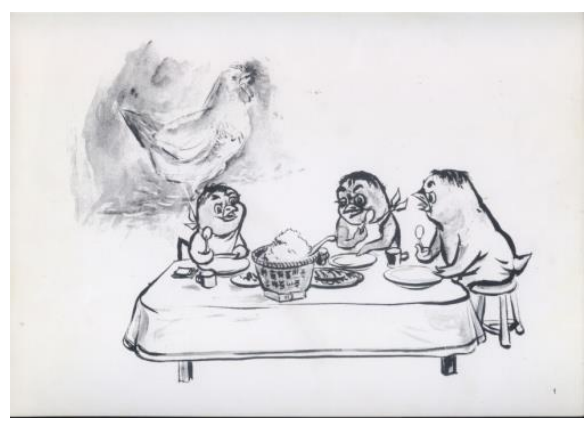

Kartu 2-A.I : Dua ekor kera yang saling menarik tali, dan tidak terlihat siapa yang akan menang atau kalah, sedangkan pada salah satu ujung terdapat anak kera yang ikut menarik tali

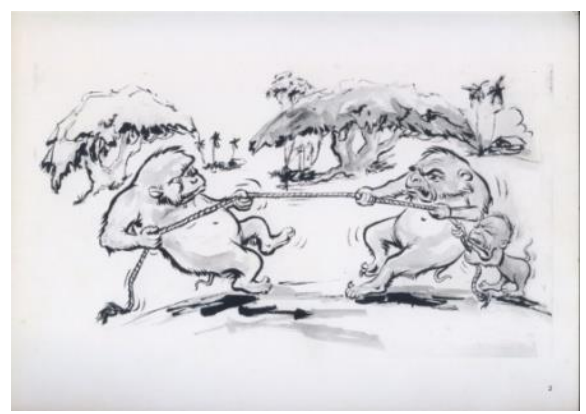


Kartu 3-A.I : Seekor singa duduk di atas kursi tahta sambil merokok diawasi oleh tikus melalui sebuah lubang.

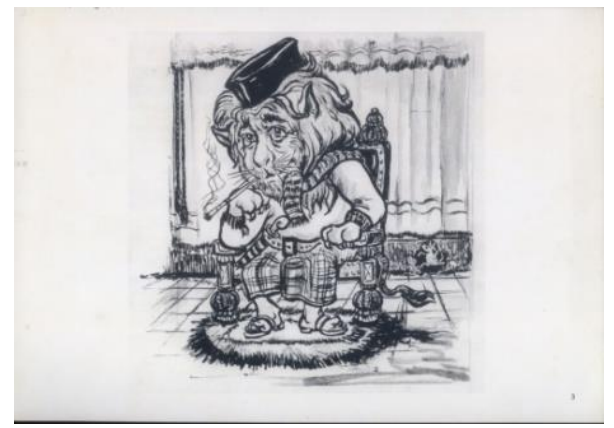

Kartu 4-A.I : Seekor kijang yang menggendong anak kijang membawa bungkusan dan keranjang berisi makanan serta payung. Sedangkan, anak kijang membawa botol susu dan memegang balon, dan anak kijang yang lebih besar di belakang naik otopet.

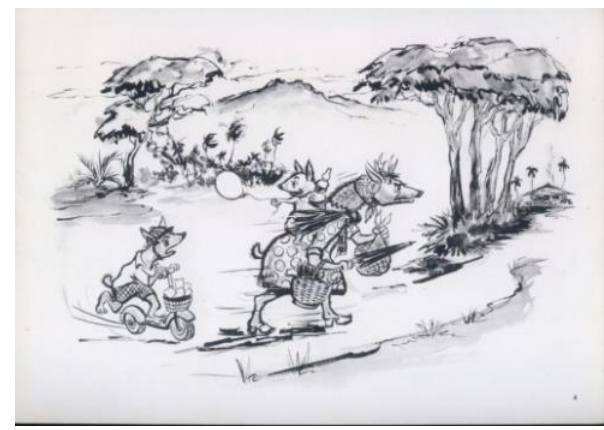

Kartu 5 : Sebuah kamar yang gelap dengan tempat tidur besar pada latar belakang, dan terdapat tempat 
tidur kecil dengan 2 bayi babi di dalamnya, dan di antaranya ada tirai pemisah.

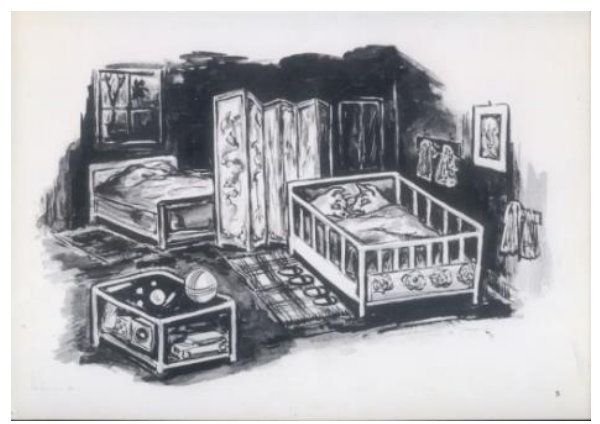

Kartu 6 : Sebuah gua yang gelap di mana dua beruang besar di latar belakang, dan disamping berbaring seekor bayi babi.

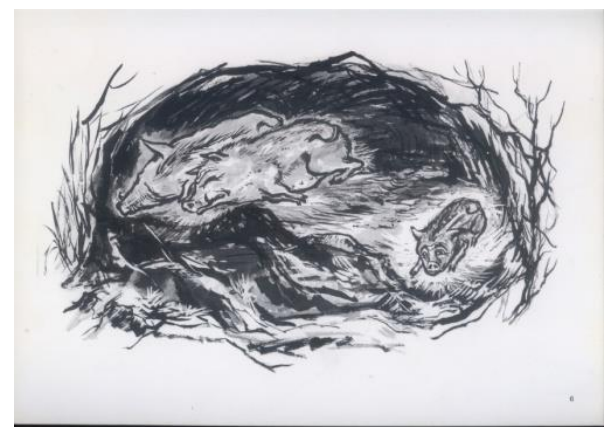

Kartu 7 : Seekor harimau ganas menunjukkan taring dan cakarnya melompat ke arah monyet yang mencoba melompat ke arah pohon. 


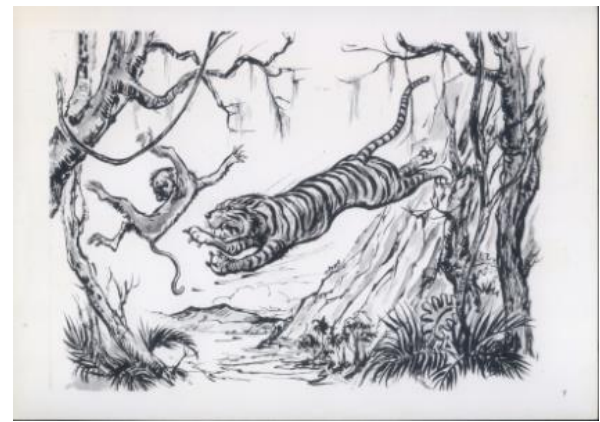

Kartu 8-A.I : Dua ekor kuda dewasa sedang duduk di bangku, minum, dan bercakap-cakap, sementara seekor kuda dewasa di depannya sedang berbicara dengan seekor anak kuda, dan pada dinding terdapat foto-foto.

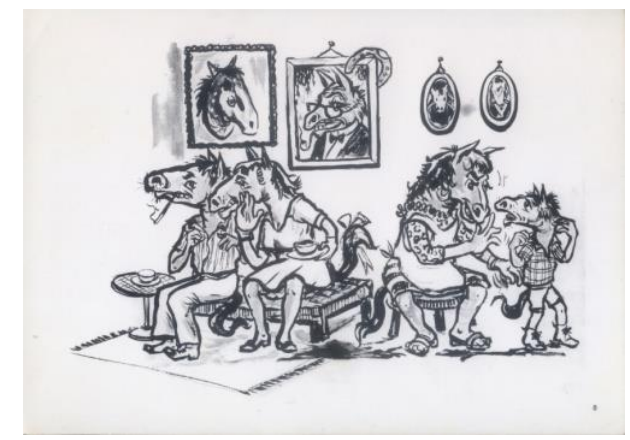

Kartu 9-A.I : Satu ruangan gelap dan terlihat ruangan lain yang terang, dan seekor anak gajah terlihat dari ruangan lain yang terang. 


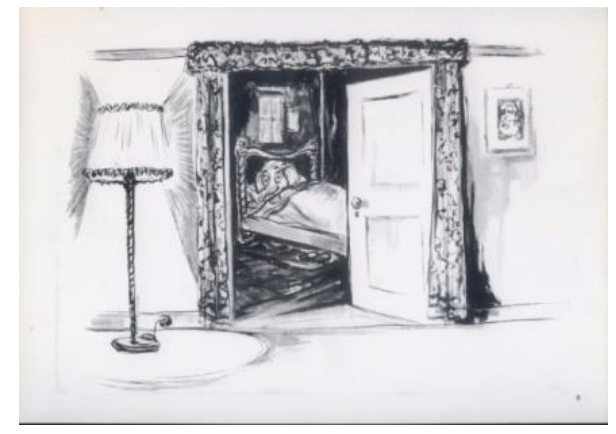

Kartu 10-A.I : Seekor anak sapi tertelungkup di atas pangkuan seekor sapi dewasa di samping kamar mandi.

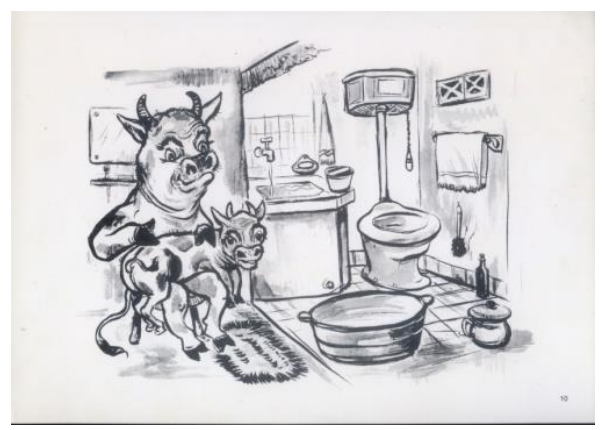

\section{Daftar Need menurut teori Murray}

Need yang diberi skor, yaitu need :

a. Abasement

- mudah mengalah pada tekanan atau paksaan untuk menghindari tuduhan, hukuman, rasa sakit atau maut. 
- mengalami tekanan yang tidak enak (seperti : penghinaan, luka, kegagalan) tanpa bisa melawan

- minta ma'af, berjanji untuk memperbaiki hidup, menyerahkan diri secara pasif dalam keadaan hidup yang hampir tidak bisa dipikul lagi.

\section{b. Achievement}

- bekerja untuk sesuatu yang penting dengan energi dan tekad.

- berusaha mencapai sesuatu yang bisa menunjukkan kredibilitasnya.

- melanjutkan usaha, meyakinkan atau memimpin kelompok, menciptakan sesuatu.

- ambisi yang tampak dalam perbuatan.

c. Aggression, yang masih bisa dibedakan menjadi 4 :

\section{c.1. Emosional dan Verbal}

- membenci (diekspresikan dalam kata-kata ataupun tidak), marah, bertengkar dengan adu mulut, mengutuk, mengkritik, menghina, memperingatkan, menyalahkan, menertawakan.

\section{c.2. Physical, Social}

- berkelahi atau membunuh untuk membela diri atau membela orang yang dicintai.

- membalas dendam terhadap penghinaan tanpa alasan atau terhadap perlakuan tidak adil.

- berjuang untuk negara sendiri atau negara sahabat dalam suatu perang.

- menghukum tindakan tercela

\section{c.3. Physical, Asocial}


- mendorong, menyerang, melukai, atau membunuh manusia

- tindakan kejahatan (berantem tanpa alasan, membalas perasaan disakiti dengan tindakan kejam, pengrusakan yang berlebihan)

- berjuang melawan pihak yang berwenang

- mengkhianati, dan berjuang melawan negara sendiri

\section{c.4. Destruction}

- melawan atau membunuh binatang

- mematahkan, membanting, membakar atau merusak obyek

\section{d. Dominance}

- mencoba untuk mempengaruhi perilaku, sentiment (perasaan), atau ide-ide orang lain

- bekerja untuk untuk meraih posisi eksekutif

- memimpin, mengatur, atau memerintah

- memaksa, melarang, memasukkan ke penjara

e. Intraggression

- menyalahkan, mengkritik, menegur atau meremehkan diri sendiri ka-rena melakukan kesalahan, karena kebodohan atau kekeliruan sendiri.

- merasa rendah diri, merasa bersalah, merasa menyesal.

- menghukum diri sendiri secara fisik, bunuh diri.

f. Nurturance 
- menunjukkan tindakan simpati, bersikap baik dan mau mempertimbangkan perasaan orang lain, memberi dorongan, rasa kasihan, dan menghibur.

- memberi bantuan, memberi perlindungan, mempertahankan atau me-nyelamatkan obyek

g. Passivity

- menikmati ketenangan, rileks, tidur.

- merasa lelah atau malas setelah melakukan sedikit usaha.

- menikmati kontemplasi pasif (melamun) .

- menyerah pada orang lain, apatis, bersikap lamban.

h. Sex

- mencari dan menikmati pergaulan dengan lawan jenis.

- melakukan hubungan seksual.

- jatuh cinta, menikah.

\section{i. Succorance}

- mencari bantuan atau hiburan.

- meminta, atau tergantung pada orang lain, meminta dukungan, ma'af, dukungan, perlindungan, perhatian.

- menikmati mendapat simpati, penghargaan atau pemberian yang ber-manfaa'at.

- merasa kesepian dalam kesendirian, kangen berada di tempat yang asing, tanpa bantuan saat mengalami krisis.

2. Need yang tidak diberi skor :

\section{a. Acquisition}

\section{a.1. Sosial :}


- bekerja untuk uang, kekayaan atau hak milik.

- mencoba mendapatkan barang beharga.

- melakukan barter, perdagangan atau perjudian.

- tamak, rakus, atau ingin memperoleh kekayaan yang tampak pada tindakannya.

\section{a.2. Asosial}

- mencuri, menipu, menyelundupkan, memalsu.

b. Affiliation

\section{b.1. Asosiatif}

- memusat : menikmati kehadiran teman setia; bekerja dan ber-main bersama; merasa memiliki kecintaan yang dalam (baik dinyatakan atau tidak) kepada orang tertentu.

- difus : menyukai berbagai orang ; berkelompok dan bermasyarakat ; bekerja atau bermain dengan kelompok.

b.2. Emosional

- terikat oleh kecintaan yang mendalam; simpati atau hormat pada orang lain ; jatuh cinta, menikah, dan tetap setia.

\section{c. Autonomy}

\section{c.1. Kebebasan}

- membebaskan diri atau menghindari lingkungan yang mengekang atau memaksa.

- membebaskan diri dari lingkup yang terbatas, lari dari penjara. 
- melarikan diri dari rumah, meninggalkan sekolah, keluar dari pekerjaan atau membelot dari ketentaraan karena adanya larangan-larangan, kewajiban dan keharusan.

- meninggalkan atau melepaskan diri dari seseorang untuk membebaskan diri dari kewajiban ikatan, tekad untuk tetap bebas.

\section{c.2. Bertahan}

- menolak paksaan.

- menolak melakukan apa yang dituntut orang.

- mendebat pertimbangan atasan.

- berpikir kontroversi, negativism, tidak mau mundur dari pendapatnya, tidak patuh.

\section{c.3. Asosial}

- melakukan sesuatu sampai taraf yang membahayakan, sesuatu yang dilarang, sesuatu yang dikritik, atau sesuatu yang bisa kena hukuman.

- kelakuan jelek, tidak menurut aturan, melanggar tata tertib, melanggar standar moral dan sosial.

- menipu, curang, berjudi, mabuk, ke pelacuran.

\section{d. Blamavoidance}

- takut diperingatkan, disalahkan atau dihukum, dan menghindari ke-keliruan.

- menahan diri dari keinginan untuk melakukan sesuatu yang tidak umum atau akan mendatangkan kritik.

- mengakui kesalahan, meminta ma'af, berjanji memperbaiki diri, menyesal agar terhindar dari dipersalahkan. 
- kembali ke jalan yang benar dan menjadi orang baik.

\section{e. Cognizance}

- ingin tahu; memandang sesuatu dengan intens.

- mengawasi, mengintip, berusaha ingin tahu lebih banyak, mengajukan pertanyaan-pertanyaan yang bersifat menyelidik.

- mencari sesuatu, meneliti, melakukan eksplorasi, atau bertindak seperti : detektif, voyeurism.

\section{f. Deference}

f.1. Patuh

- menyerah pada keinginan, saran, paksaan orang sekutunya.

- siap menyenangkan, menyetujui, bekerja sama, menuruti dengan se-nang hati kepemimpinan orang yang dikagumi.

f.2. Hormat

- menyatakan hormat dan kagum dalam bentuk tindakan; kultus individu ; mengakui jasa, bakat ; memuji prestasi yang baik.

\section{g. Excitance}

- mencari rangsang emosional dengan berbagai cara.

- bepergian, berpetualang dengan wanita.

- judi, menyerempet-nyerempet bahaya.

\section{h. Exposition}

- memberi informasi, berita; menerangkan; memberi petunjuk; mengajar.

\section{i. Harmavoidance}


- menunjukkan ketakutan, kecemasan, kebingungan, malu, menghindari perkelahian atau bahaya karena takut terluka, sakit atau mati.

- melarikan diri ketika dikejar binatang, musuh atau polisi (takut dipenjara secara fisik).

j. Change, travel, Adventure

- gelisah dan selalu berpindah-pindah.

- haus akan pemandangan baru, tempat baru.

- mencari petualangan ; memimpikan kunjungan ke negeri jauh atau negara asing ; bepergian ; pergi melakukan eksplorasi ; mencari harta karun.

\section{k. Construction}

- mengorganisir, mengatur, membangun atau menciptakan sesuatu.

\section{Counteraction}

- berjuang untuk mendapatkan kembali atau mempertahankan kehormatan diri, kebanggan yang terlukai atau terancam.

- menambah usaha setelah kegagalan, atau mencoba dan mencoba lagi atau mati-matian menaklukkan hambatan yang besar.

m. Nutriance

- mencari dan menikmati makanan dan minuman, merasa lapar dan haus.

- minum minuman keras dan obat-obatan.

- melakukan pekerjaan yang berhubungan dengan makanan dan minuman. 


\section{n. Playmirt}

- bermain, meluangkan waktu hanya untuk bersenang - senang, pergi ke pesta.

- melucu, tertawa, berolok-olok.

- menghadapi situasi dengan cara santai atau mainmain.

o. Retention

- memegang teguh suatu obyek, menolak meminjamkan, berusaha menghindarkannya dari pencurian, menyembunyikan dari banyak orang.

- menimbun, mengoleksi, melestarikan, hemat, dan kikir.

p. Understanding

- berjuang untuk memperoleh pengetahuan dan kebijaksanaan.

- giat belajar di sekolah, mendapat pendidikan, membaca agar memperoleh pengetahuan.

q. Rejection

- menyatakan ketidakpuasan, ketidaksenangan, atau kemarahan dalam bentuk tindakan.

- menghindari sesuatu, seseorang, suatu pekerjaan, atau ide-ide yang asing dari minatnya.

\section{r. Sentience}

\section{r.1. Epiqurean}

- mencari dan menikmati kenyamanan, kemewahan, kemudahan, rasa senang.

r.2. Aesthetic 
- sensitif terhadap aspek rangsangan alam.

- menikmati seni, musik, sastra.

- menciptakan, membuat komposisi, menulis karangan, dsb.

\section{Daftar Press menurut teori Murray}

Berikut daftar press dengan kekuatannya :

a. P. Affiliasi

1. Asosiatif

- Hero memiliki seorang teman atau lebih, atau sahabat. Hero menjadi anggota klub.

2. Emosional

- Seseorang (bisa ayah, ibu, saudara kandung, keluarga lain, pacar) berdedikasi pada hero. Hero mencintai dan dicintai, atau menikah.

b. P. Agresi

1. Emosional dan verbal

- Seseorang marah, membenci hero. Hero dikritik, dihina, ditertawai, atau difitnah.

2. Fisik, Sosial

- Hero dalam posisi bersalah (dalam cerita : hero adalah seorang penyerang, penjahat) dan seseorang mempertahan diri, membalas, mengejar, memenjarakan, atau membunuh hero. Tokoh lain (bisa pemerintah, polisi, ayah, ibu) memberi hukuman pada hero karena berkelakuan kurang baik.

3. Fisik, Asosial

- Seorang penjahat, atau suatu geng menyerang, melukai, atau membunuh hero. Seseorang 
memulai suatu perkelahian dan hero mempertahankan diri.

4. Perusakan hak milik

- Milik hero dirusak, atau dihancurkan.

c. P. Dominance

1. Coercion/Paksaan

- Seseorang (bisa ayah, ibu, atau pihak berwenang) mencoba memaksa, memerintah, menyuruh hero melakukan sesuatu.

2. Restraint/Larangan

- Seseorang mencoba mencegah (dalam bentuk pengawasi, melarang, atau menghambat) hero untuk melakukan sesuatu.

3. Inducement, Seduction/Ajakan

- Seseorang mencoba memaksa hero untuk melakukan sesuatu, dengan jalan meminta, mempengaruhi, memberi dorongan, menggunakan strategi yang cerdik, atau menawan hatinya.

d. P. Nurturance

Seseorang memberi makan, minum, memberi dorongan, perlindungan, atau perawatan, pada hero. Hero mendapat simpati, terhibur, dan dikasihani.

e. P. Rejection

Seseorang menolak, memarahi, tidak hormat lagi, tidak mengakui, tidak sudi, atau meninggalkan hero.

f. P. Lack, Loss 


\section{Lack}

- Hero tidak memiliki apa yang dibutuhkan untuk hidup, untuk berbahagia, atau untuk berhasil. Hero miskin, keluarganya melarat.Hero tidak memiliki martabat, pengaruh, teman. Hero tidak memiliki kesempatan untuk bersenang-senang, atau maju.

2. Loss

- Hero kehilangan sesuatu atau seseorang.

g. P. Physical Danger

1. Active

- Hero terkena bahaya fisik, bukan karena manusia, binatang buas, tabrakan kereta api, petir, angin rebut, dan sebagainya.

2. Insupport

- Hero dalam bahaya : jatuh atau tenggelam, mobilnya terbalik, kapalnya rusak, kapal terbangnya tidak beres, atau ia ada di ujung tebing.

h. P. Physical Injury

Hero dilukai seseorang (P. Aggresion), dilukai binatang atau luka karena kecelakaan ( P. Physical Danger), badannya terpotong atau rusak.

\section{Daftar Defense Mechanism}




\section{Represi (Repression)}

Mekanisme dimana seseorang yang memiliki keinginan keinginan, impuls pikiran, kehendak yang tidak sesuai dan mengganggu kebutuhan/motivasinya, disingkirkan dari alam sadar dan ditekan ke dalam alam bawah sadar.

Secara tidak sadar seseorang menekan pikiran pikiran yang tidak sesuai atau menyedihkan keluar dari alam sadar ke alam tak sadar. Repression yang terus menerus akan menjadi tumpukan kekecewaan sehingga menjadi "kompleks terdesak"

Contoh: Seorang pemuda melihat kematian temannya waktu kecelakaan, kemudian "lupa" tentang kejadian tersebut. (lupa ini disebut amnesia yang psikogenik, bila lupa karena gegar otak maka disebut amnesia organik).

\section{Kompensasi (Compensation)}

Mekanisme dimana seseorang mengabdikan dirinya kepada mengejar suatu tujuan, dengan usaha yang lebih giat ke dalam usahanya itu untuk mengatasi rasa kekurangan yang sebenarnya atau yang hanya dirasakan saja.

Menutupi kelemahan dengan menonjolkan sifat yang baik atau karena frustrasi dalam suatu bidang, lalu dicari kepuasan secara berlebihan dalam bidang yang lain (kompensasi berlebihan). Kompensasi dilakukan terhadap perasaan kurang mampu (inferior).

Contoh: Anak yang tidak pandai di sekolah, menjadi anak jagoan atau ditakuti oleh teman-temannya).

\section{Konversi (Conversion)}


Mekanisme dimana konflik emosional memperoleh ekspresi luar melalui manifestasi motorik, sensoris, somatik.

Contoh: Saat stres menjadi mudah marah, teriak-teriak, atau berolahraga.

\section{Penyangkalan (Denial)}

Proses mekanisme dimana seseorang menghindarkan kenyataan yang menimbulkan sakit dan rasa cemas, dengan secara tidak sadar menyangkal adanya kenyataan, yang disangkal itu mungkin berupa suatu pikiran, keinginan, atau suatu keadaan dan benda. Menyangkal realitas yang menimbulkan rasa takut, sakit, malu, atau cemas.

Contoh: Seorang ibu tidak mau menerima bahwa anaknya terbelakang mental sehingga anak tersebut dititipkan pada saudaranya yang jauh.

\section{Memindahkan (Displacement)}

Proses mekanisme dimana emosi2 yang tertahan diberikan tujuan yang lain ke arah ide, objek, atau orang orang lain daripada ke sumber primer emosi. Luapan emosi terhadap seseorang atau objek dialihkan kepada seseorang atau objek yang lain.

Contoh: Seorang anak yang dimarahi ibunya kemudian dia memukul adiknya atau menendang kucingnya.

\section{Disosiasi (Dissociation)}

Beban emosi dalam suaatu keadaan yang menyakitkan diputus atau diubah. Mekanisme dimana suatu kumpulan proses proses mental dipisahkan atau diasingkan dari 
kesadaran dengan bekerja secara merdeka atau otomatis, afek dan emosi terpisah, dan terlepas dari ide, situasi, objek, misalnya pada selektif amnesia.

Contoh : Rasa sedih karena kematian seorang kekasih dikurangi dengan mengatakan "sudah nasibnya" atau "sekarang ia sudah tidak menderita lagi".

\section{Fantasi (Fantasy) atau Khayalan (Image)}

Suatu proses melamun (menerawang) atau tindakan berkhayal untuk memberikan pelarian dari kenyataan, dengan kepuasan diperoleh dan pencapaian pencapaian kenikmatan yang bersifat khayal atau mati sebagai pahlawan yang tidak berdosa.

Contoh: Seorang anak yang kurang pandai lalu berkhayal dirinya menjadi bintang pelajar.

\section{Identifikasi (Identification)}

Suatu mekanisme dimana seseorang mempertinggi harga dirinya dengan mempolakan dirinya serupa dengan orang lain (tabiatnya meniru orang lain). Menambah rasa harga diri dengan menyamakan harga dirinya seperti seorang atau suatu hal yang dikaguminya.

Contoh: Seorang anak yang bersolek atau berdandan seperti ibunya, atau malah bersolek seperti bintang iklan.

\section{Introyeksi (Introjection)}

Proses dimana seseorang mengambil ke dalam struktur egonya sendiri, semua atau sebagian dari kepribadiannya sendiri. 
Contoh: Seorang anak yang membenci seseorang tapi "memasukkan" ke dirinya sendiri, hingga jika ia kesal ke orang tersebut ia akan memukuli dirinya sendiri.

\section{Negativisme (Negativism)}

Proses perlawanan yang aktif atau pasif terhadap permintaan permintaan yang ditujukan kepada seseorang. Negativisme aktif kalau seseorang berbuat kebalikan dari apa yang diminta darinya. Negativisme pasif kalau ia menghindarkan apa yang diharapkan daripadanya.

Contoh: Seorang anak yang disekolahkan tidak sesuai dengan minatnya maka ia sering bolos sehingga prestasinya menjadi kurang.

\section{Proyeksi (Projection)}

Mekanisme dengan apa seseorang melindungi dirinya dari kesadaran akan tabiat- tabiatnya sendiri yang tidak baik, atau perasaan-perasaan dengan menuduhkannya kepada orang lain. Menyalahkan orang lain mengenai kesulitannya sendiri yang tidak baik.

Contoh: Seorang murid tidak lulus lalu mengatakan gurunya sentimen kepada dia.

\section{Rasionalisme (Rationalization)}

Mekanisme dimana seseorang membenarkan tingkah lakunya yang tidak konsekuen dan tidak baik. Termasuk membenarkan kepercayaan, keterangan, alasan alasan (motivasi) dengan memberikan penjelasan dan keterangan baginya. Berusaha untuk membuktikan bahwa 
perbuatannya (yang sebenarnya tidak baik) dianggap rasional adanya, dapat dibenarkan, dan dapat diterima.

Contoh: Seorang anak menolak bermain bulu tangkis dengan temannya karena "kurang enak badan" atau "besok ada ulangan" (padahal takut kalah).

\section{Pembentukan Reaksi (Reaction Formation)}

Proses dimana seseorang mengambil kedalam struktur egonya sendiri, semua atau sebagian dari suatu objek, yang kemudian dianggap sebagai suatu unsur dari kepribadiannya sendiri. Supaya tidak menuruti keinginannya yang jelek, maka sebagai penghalang diambil sikap atau perilaku yang sebaliknya.

Contoh: Seorang mahasiswa yang bersikap hormat secara berlebihan terhadap dosen yang sebenarnya tidak ia suka.

\section{Regresi (Regression)}

Keadaan dimana seseorang kembali ke tingkat yang lebih awal dan kurang matang dalam adaptasi. Bentuknya yang ekstrim adalah tingkah laku infantil (kekanak-kanakan). Keadaan seorang yang kembali ke tingkat perkembangan yang sebelumya dan kurang matang dalam adaptasi.

Contoh : Seorang anak yang sudah tidak ngompol, mendadak ngompol lagi karena cemas mau masuk sekolah atau mulai menghisap jempol lagi setelah ia memiliki adik, karena merasa perhatian ibunya terhadap dirinya berkurang.

\section{Sublimasi (Sublimation)}


Proses dengan apa kehendak tidak sadar dan tidak dapat diterima, disalurkan menjadi aktivitas yang memiliki nilai sosial yang tinggi. Dorongan atau kehendak kehendak yang tidak dapat disalurkan menjadi aktivitas yang memiliki nilai sosial.

Contoh : Seseorang suka berkelahi kemudian ia menjadi atlet petinju.

\section{Menghapuskan (Undoing)}

Mekanisme dimana seseorang secara simbolis melakukan kebalikan sesuatu yang telah dikerjakannya, atau pikiran yang tidak dapat diterima oleh egonya dan masyarakat. Dia secara simbolis menghapus pikiran, perasaan, atau keinginan yang tidak dapat diterima egonya atau masyarakat.

Contoh: Seorang suami yang berselingkuh lalu ia memberi bermacam-macam hadiah kepada istrinya.

\section{Simpatisme}

Berusaha mendapatkan simpati dengan jalan menceritakan berbagai kesukarannya, misalnya penyakit atau kesulitan kesulitan lainnya. Bila ada yang menyatakan simpati kepadanya maka rasa harga dirinya diperkuat, biarpun ada kegagalan.

Contoh: Seorang siswa yang mengeluh bahwa dia tidak mempunyai buku buku pelajaran karena orangtuanya miskin dan tidak bisa membelikannya, lagipula ibunya sakit sakitan. 
VI. Form Interpretasi Bellak (Bellak, L, 1975)

\section{A. Long-Form}

(halaman 1)

BELLAK TAT BLANK

For Recording \& Analysing TAT stories

Nama:.......................... J.K.: ........ Usia :

$\operatorname{tg} \mid$

Pendidikan:

Pekerjaan :

Direfer oleh:

Dianalisis oleh :

LAPORAN AKHIR

Umum :

Khusus : 
(halaman 2)

I. RECORDING BLANK

\begin{tabular}{|c|c|c|}
\hline $\begin{array}{c}\text { Tema } \\
\text { deskriptif }\end{array}$ & Tema interpretif & $\begin{array}{c}\text { Tema } \\
\text { diagnostik }\end{array}$ \\
\hline & & \\
& & \\
& & \\
& & \\
& & \\
\end{tabular}


Catatan klinis 
(halaman 3)

\section{ANALYSIS SHEET}

Nama :

Cerita ke

(gb.

TAT no :

)

1. Tema Utama :

2. Tokoh Utama : usia ........ jenis kelamin

pekerjaan minat

adekuasi $(\mathrm{V}, \mathrm{V} \mathrm{V}, \mathrm{V} \mathrm{V} \mathrm{V})$

kemampuan

image

body image dan/atau self-

3. Kebutuhan utama dari tokoh :

a) behavioral need dari tokoh (seperti dalam cerita)

\section{dinamika infrensi}

b) figur, obyek, atau lingkungan yang dimasukkan dalam cerita

mewakili kebutuhan akan atau pada

c) figur, obyek, atau lingkungan yang ada dalam gambar tetapi diabaikan dalam cerita

mewakili kebutuhan akan atau

pada

4. Konsep tentang lingkungan (dunia) sebagai

5. Figur orang tua (lk .., $\mathrm{pr}$..) dilihat sbg. dan reaksi sby.

Figur sebaya $(\mathrm{lk} . . ., \mathrm{pr} .$.$) dilihat sbg.$ dan reaksi

sby. 
Figur lebih muda (lk .., pr...) dilihat sbg. dan reaksi sby.

6. Konflik yang dialami

7. Sifat dari kecemasan : ( $V$ )

Hukuman fisik ...... Sakit atau luka .......Tercela ....... Deprivasi ........ Kehilangan kasih sayang ...... Diganyang

Ditinggalkan ......... Terlalu dikuasai \& tidak berdaya ........ Lain-lain

8. Mekanisme Pertahanan melawan konflik dan ketakutan : ( $\mathrm{V}$ )

Represi ....... Reaksi formasi ...... Rasionalisasi ........ Isolasi ....... Regresi ........ Introyeksi ....... Denial ....... Undoing ....... Lain-lain

9. Adekuasi super-ego seperti yang ditunjukkan pada "pemberian hukuman atas kejahatan": ( $\mathrm{V}, \mathrm{V} V, \mathrm{~V} V \mathrm{~V})$

Tepat ........ Tidak tepat ........ Berlebihan ........ Tidak konsisten ........ Terlalu lunak .......

Ditunda atau ada jeda .......... Inhibisi ....... Gagap ......... Lain-lain

10. Integrasi ego, perwujudan diri : $(\mathrm{V}, \mathrm{V} V, \mathrm{~V} \mathrm{~V} \mathrm{~V})$

Ketepatan tentang tokoh

hasil : bahagia

tidak bahagia

realistis

tidak tealistis

solusi : tepat

tidak tepat

Proses berpikir seperti yang terungkap pada alur cerita : $(\boldsymbol{V}, \mathrm{V} V, \mathrm{~V} V \mathbf{V})$

Terstruktur ...... Tidak terstruktur ...... Stereotype ....... Original ...... Tepat

........Rasional .......Aneh ....... Lengkap ........ Tidak lengkap ....... . Tidak tepat

Inteligensi : ( $\mathrm{V}$ )

Superior ........ Di atas rata-rata ....... Rata-rata ....... Di bawah rata-rata

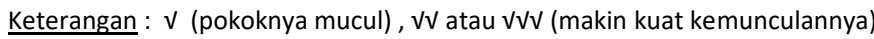

\section{RINGKASAN}

Tema-tema yang terungkap dan ringkasan data-data yang signifikan dari setiap cerita :

1. 
2.

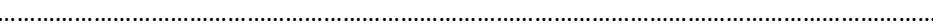

3.

烈

4.

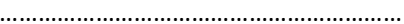

5.

6

.

7.

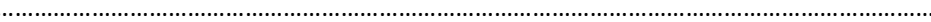

8

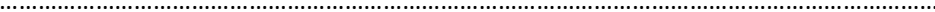

9.

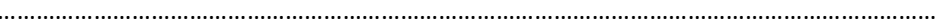

10. 


\section{B. Short- Form}

(halaman 1)

\section{SHORT FORM}

BELLAK T.A.T. BLANK

PENDIDIKAN

Lk/Pr.

DIANALISA OLEH

PEKERJAAN

KESIMPULAN 
(halaman 2)

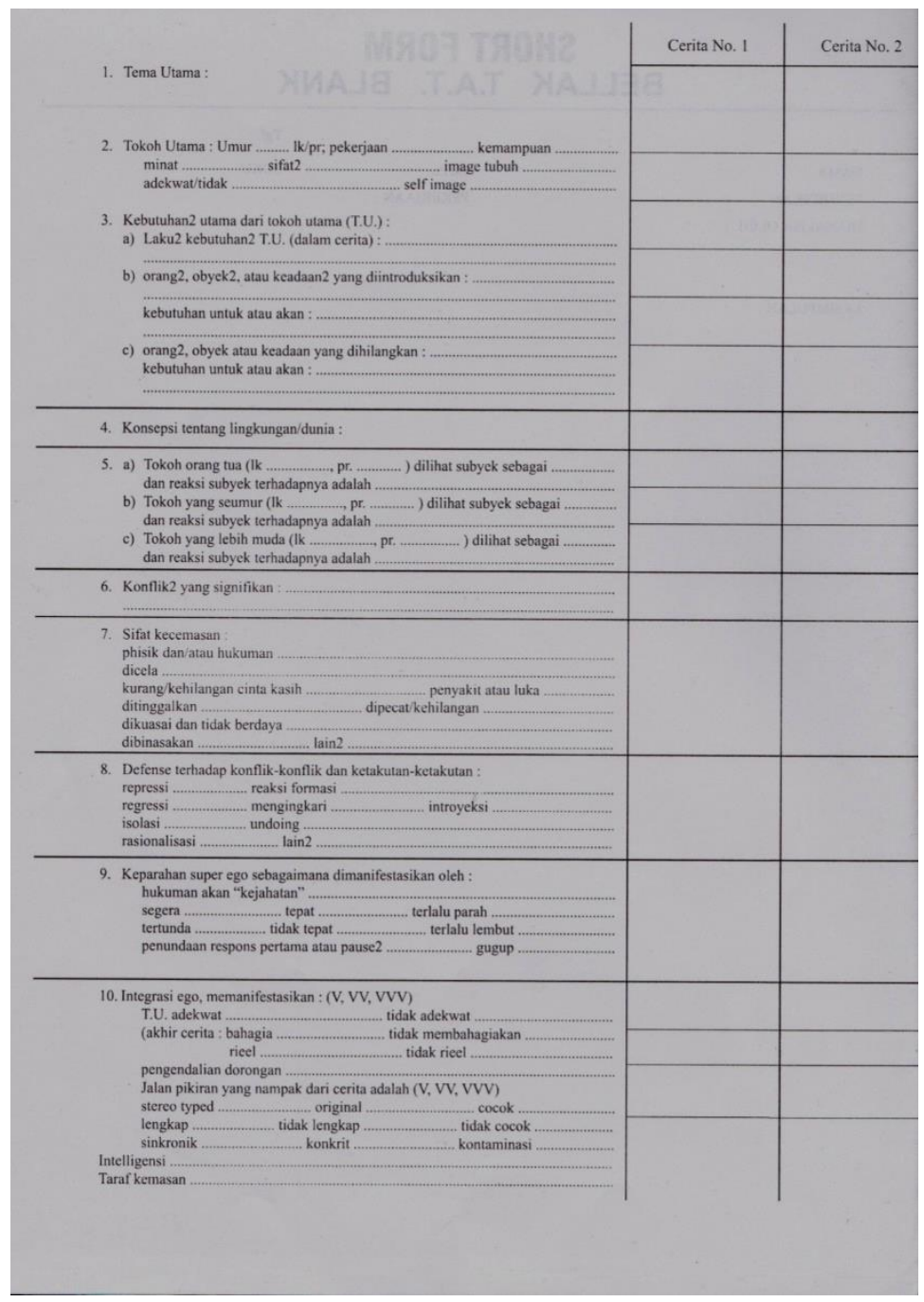


(halaman 3)

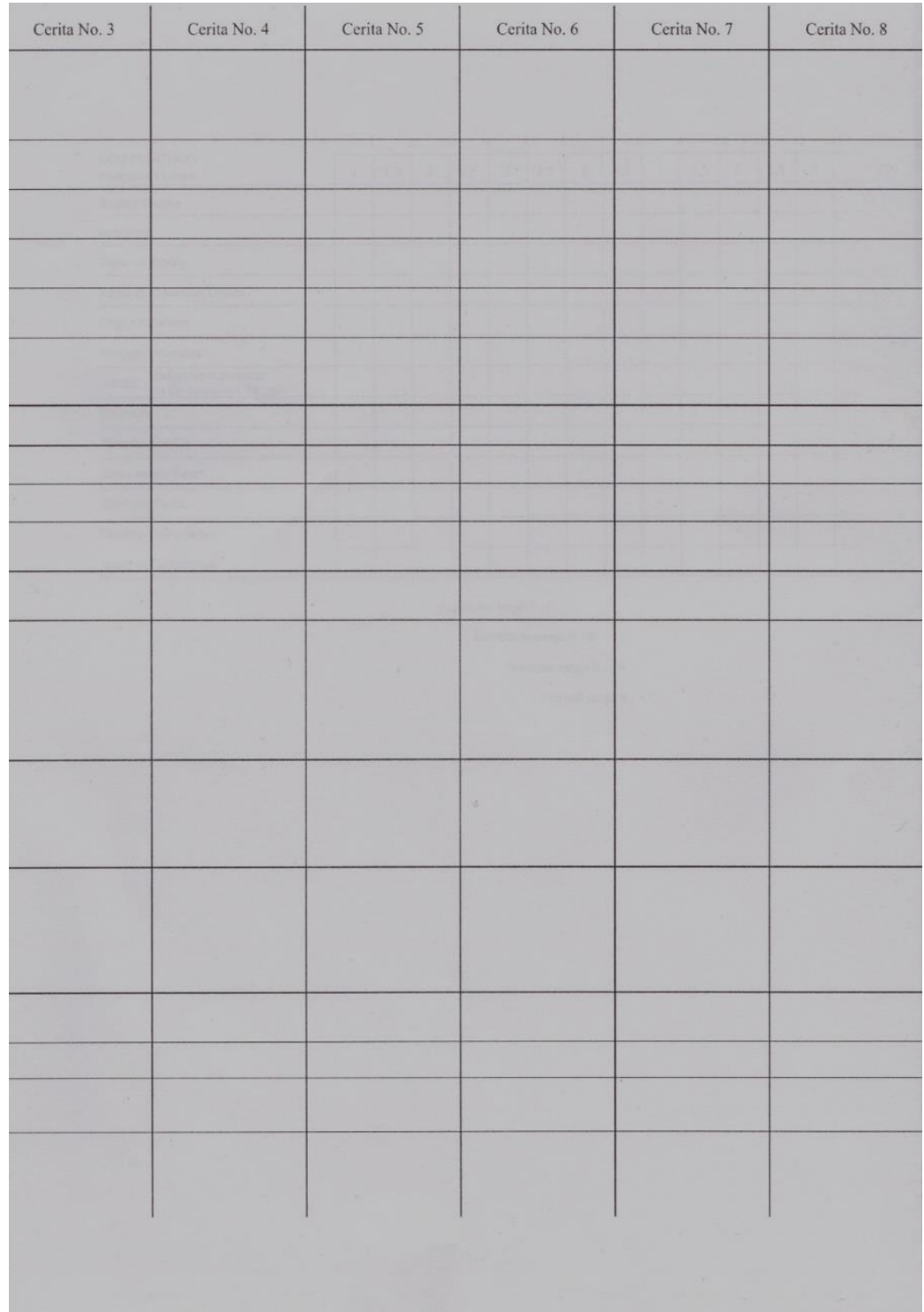


(halaman 4)

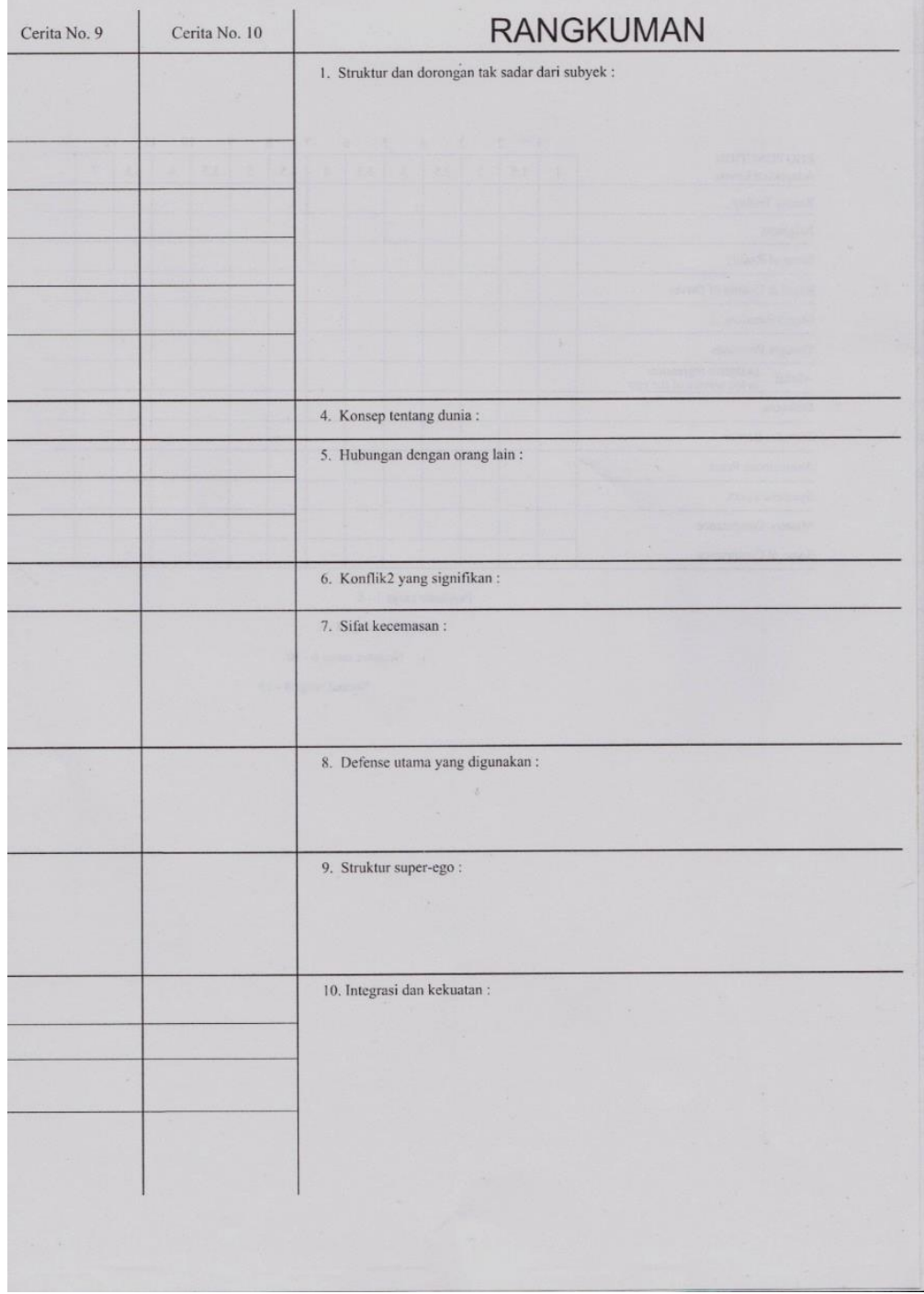




\section{(halaman 5)}

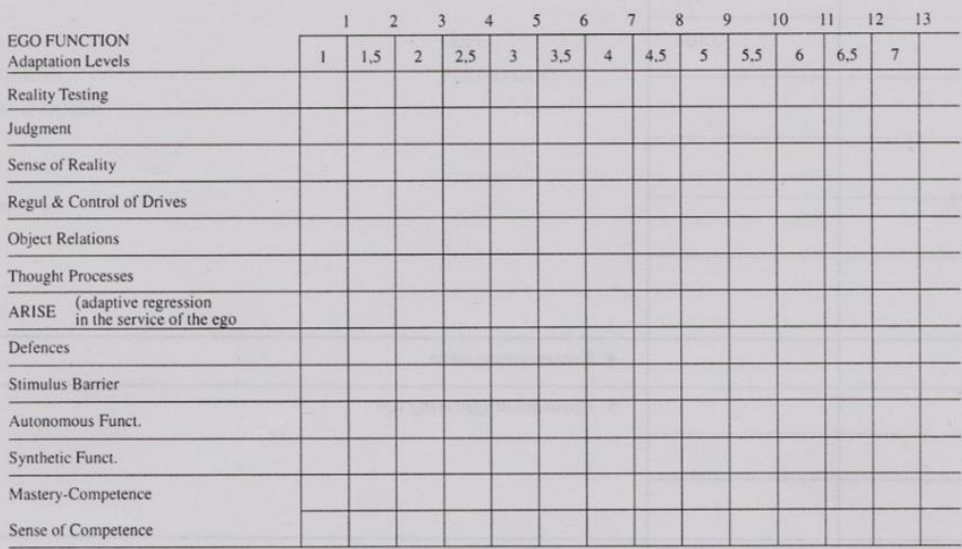

Psychotic range 1- 6

Borderline range $4 \cdot 8$

Neurotic range 6 - 10

Normal range $8-13$ 